The EFSA Journal (2005) 239, 1-85. The probability of transmission of Porcine Reproductive and Respiratory Syndrome virus (PRRSv) to naive pigs via fresh meat

\title{
Scientific Opinion on
}

"The probability of transmission of Porcine Reproductive and Respiratory Syndrome virus (PRRSv) to naive pigs via fresh meat"

EFSA-Q-2004-100

Adopted by the AHAW Panel on 14/15 June 2005 


\section{TABLE OF CONTENTS}

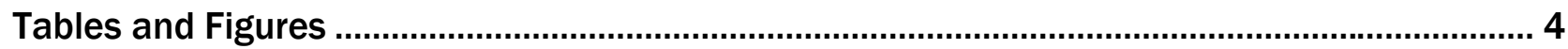

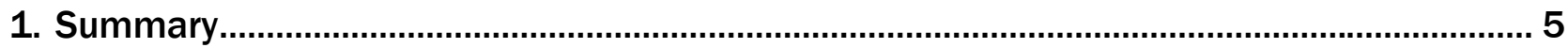

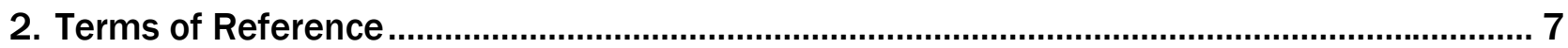

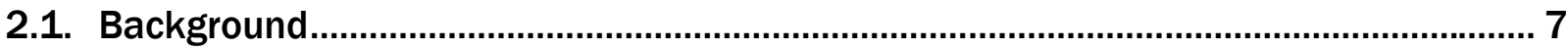

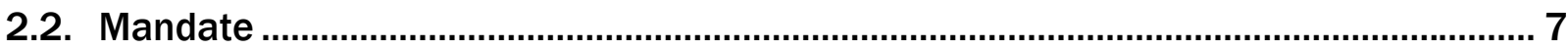

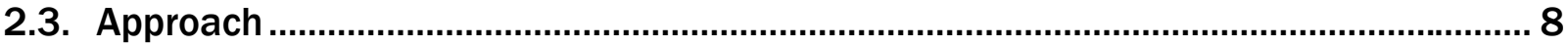

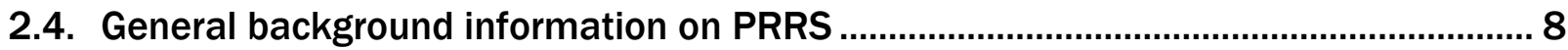

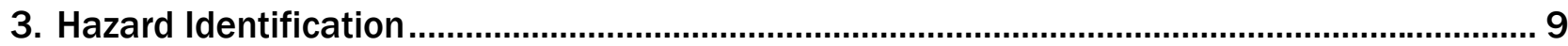

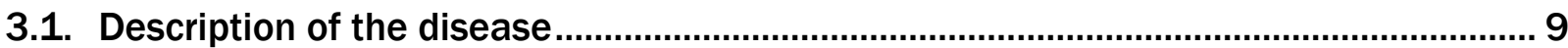

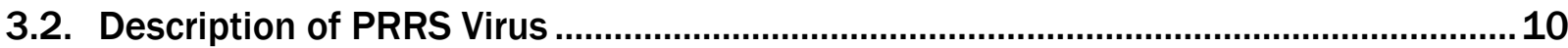

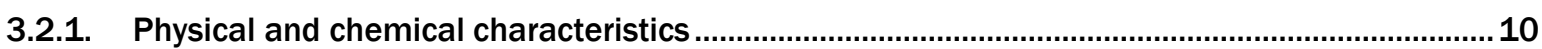

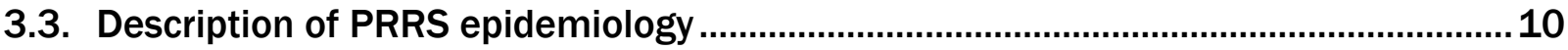

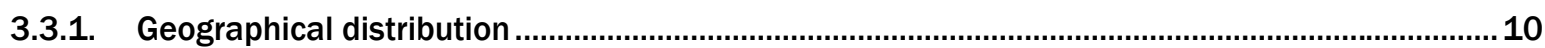

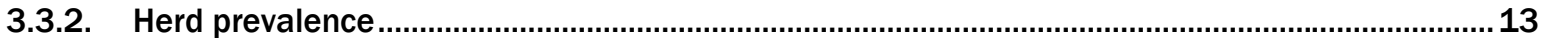

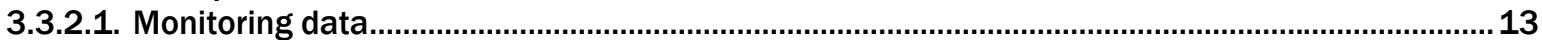

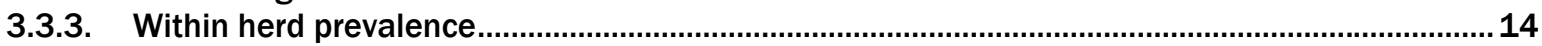

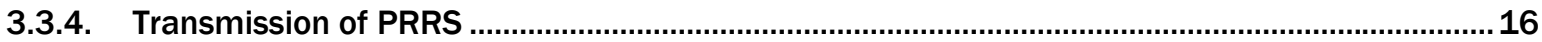

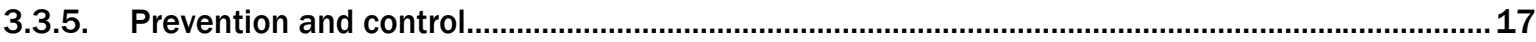

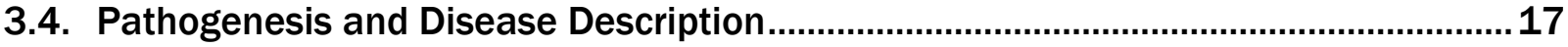

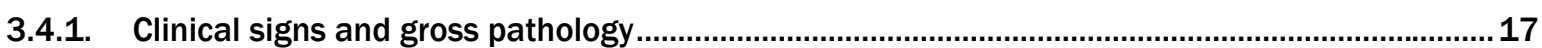

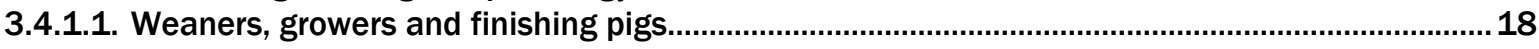

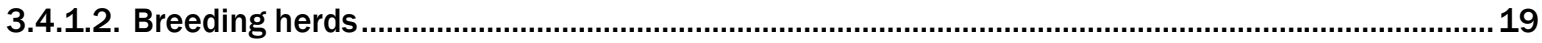

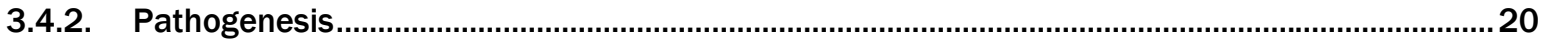

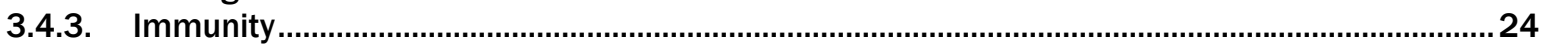

3.4.4. Specific virus degradation during meat maturation, chilling, freezing etc...................................25

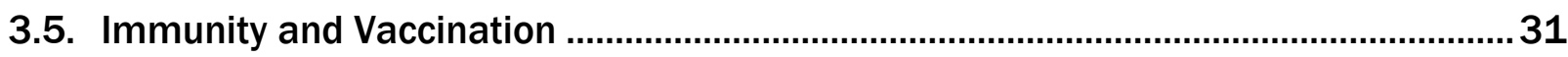

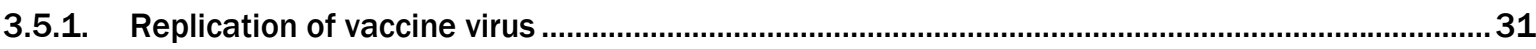

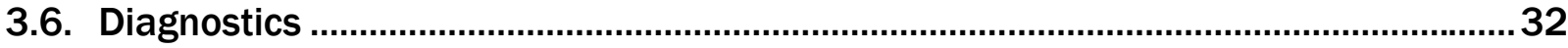

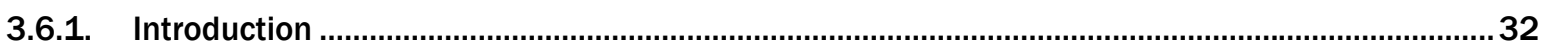

3.6.2. Interpretation of diagnostic sensitivity/specificity ..................................................................33

3.6.3. How to collect and transport samples for detection of PRRS ....................................................33

3.6.4. Assays to detect PRRSv.....................................................................................................

3.6.5. Assays to detect of serum antibodies against PRRSv (serology) ..............................................36

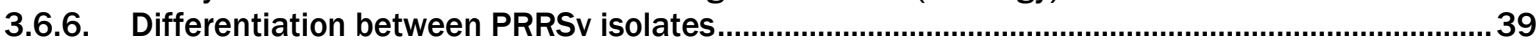

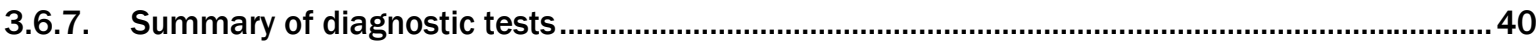

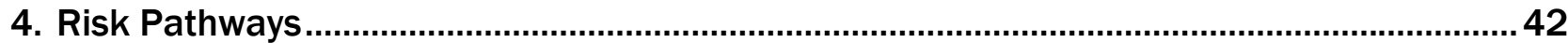

5. Risk Assessment for Risk Question 1: What is the probability of viable PRRS virus in meat?

5.1. Description of pathway and associated probabilities leading to residual PRRS virus in pig meat

6. Risk Assessment for Risk Question 2: What is the probability that viable PRRS virus in pig meat reaches naive pigs?.

6.1. Description of pathway and associated probabilities leading to exposure of PRRS virus in pig meat to naive pigs. 
6.2. Conclusion on the probability of infecting a pig with PRRSv by oral exposure to infected pig meat.

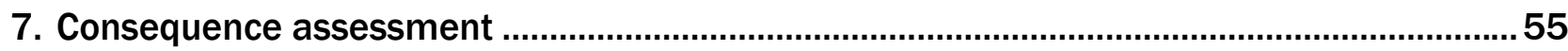

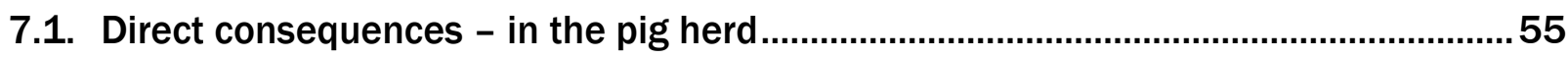

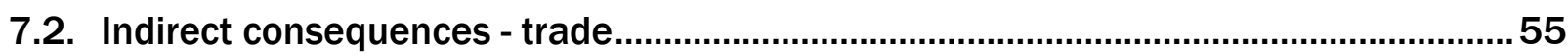

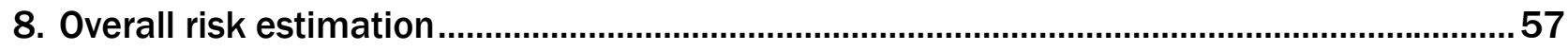

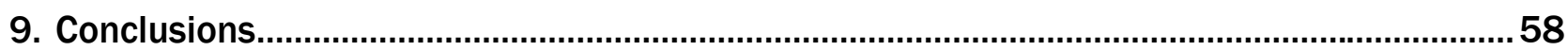

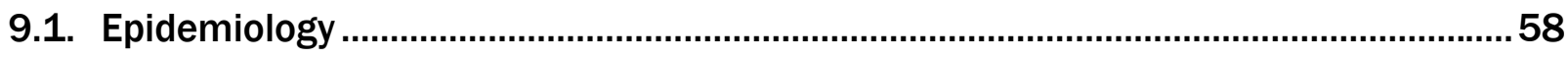

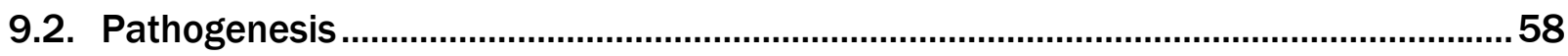

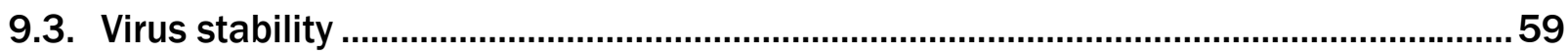

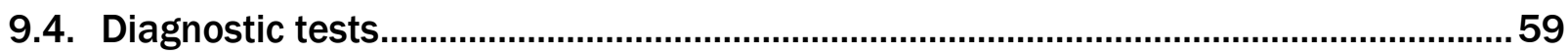

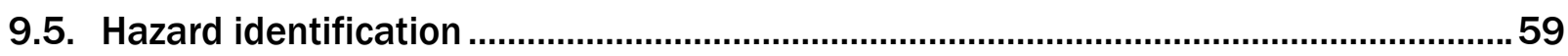

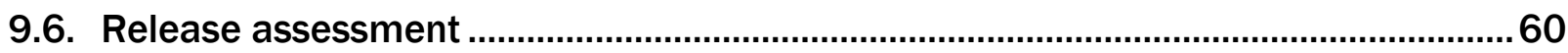

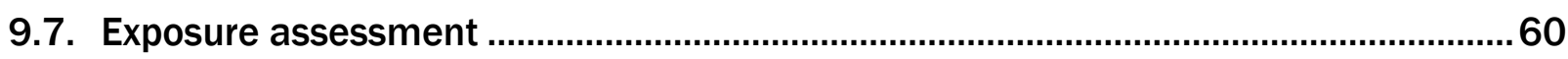

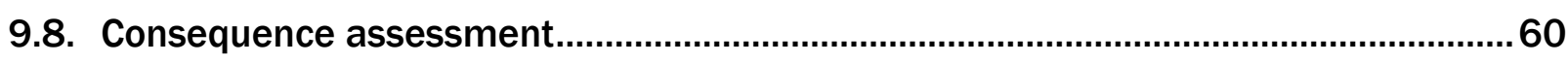

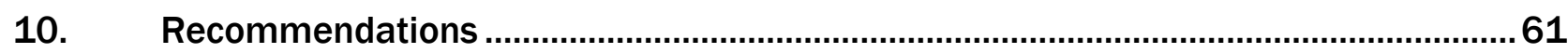

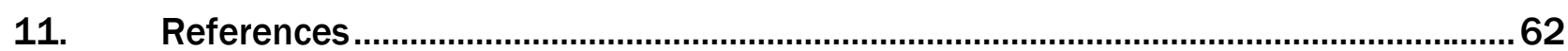

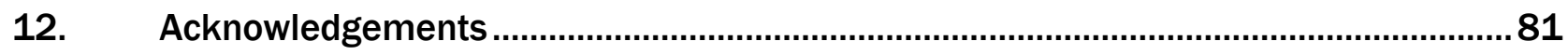

13. AHAW Scientific Panel Members ........................................................................... 83 


\section{Tables and Figures}

\section{Tables}

Table 3-1. Pig and pig meat imports into Sweden, Finland, Norway and Switzerland.. 12

Table 3-2. Data on prevalence distribution of PRRS viraemia....................................... 15

Table 3-3. Acute PRRS: Clinical signs and effects ..................................................... 19

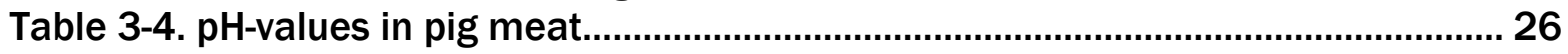

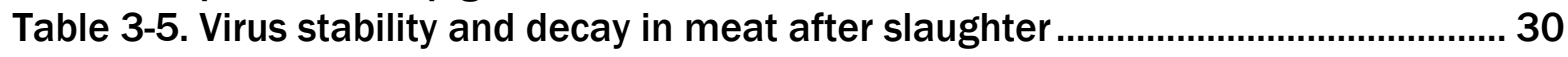

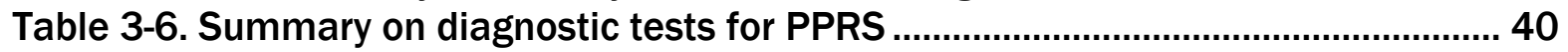

\section{Figures}

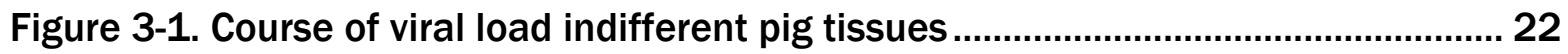

Figure 3-2. Core temperatures in different parts of the pig carcass ............................... 27

Figure 5-1. Biological pathways necessary for release of PRRS virus ............................ 43

Figure 5-2 Distribution of last day of viraemia and slaughter age .................................. 45

Figure 6-1. Distribution of PRRSv present per $\mathrm{g}$ in muscles of a viraemic pig.............. 52 


\section{Summary}

Porcine Reproductive and Respiratory Syndrome (PRRS) is a viral disease that is characterised by high abortion rates and mortality in pre-weaned pigs and respiratory disease in fattening pigs.

In the European Union, PRRS is not notifiable or subject to other harmonised disease control measures. However, several third countries, which are free of the disease, apply safeguard measures to protect their herds. International agreements demand that such safeguard measures should be proportionate to the risk involved. However, available data on the prevalence of the virus, its tissue distribution during the different phases of the disease, its degradation during meat maturation, its survival in the environment and other factors influencing the release of the virus are not sufficiently consolidated and evaluated to allow the Commission to draw a clear picture of the risk of virus release.

The Commission therefore asked the European Food Safety Authority (EFSA) to assess the risk of transmitting PRRS via fresh pig meat to naive pig populations, which may be exposed to the virus via (illegal) feeding of catering waste (swill) or by other contact with animal waste.

The mandate was accepted by the Panel on Animal Health and Welfare (AHAW) at the Plenary Meeting, on 14 September 2004. It was decided to establish a Working Group of AHAW experts chaired by one Panel member. The risk assessment addressing the risk questions specified by the Commission follows the methodology for RA which can be summarised as hazard identification, release assessment, exposure assessment, consequence assessment and overall risk estimation.

PRRSv replicates only in a limited number of cell types. Permissive cells include pulmonary macrophages and cells of the monocyte/macrophage lineage in lungs, tonsils, lymph nodes and spleen whereas muscle cells are not considered permissive. In the early stages of infection virus can be found in high titres in most organs and blood and may persist for extended periods in the lungs and tonsils.

Based on the age-related pattern of incidence of PRRSv-infection in endemically infected populations and the tissue distribution of the virus during viraemia it is considered likely, that a small fraction of slaughter pigs will be replicating PRRSv at the time of slaughter. The lack of clear clinical or pathological signs of replication in slaughter-age pigs precludes detection by ante mortem and/or post mortem inspection.

Systematic use of live vaccines in young and growing pigs may lower the likelihood of viral presence in animals at the time of slaughter but it is considered that under practical conditions vaccination will only marginally limit the overall risk of transmission of the virus via fresh meat. Vaccine viruses may be present in slaughtered pigs and thus could present a hazard to naive populations.

The available data on reduction of infectivity during maturation, chilling, and freezing of fresh meat are somewhat variable but may on average be expected to lead to 2 $\log _{10}$ reduction of infectivity. Treatments such as de-boning or removal of lymph nodes will not be able to remove infectivity from carcasses.

The rate of inactivation of PRRSv is highly temperature-dependant, therefore the probability of survival of the virus in catering waste (swill) will depend on both ambient 
temperature and time before swill is actually being fed to pigs. The minimal oral infectious dose is not known but the observation that meat containing PRRSv detectable by PCR but below the detection limit for virus isolation in vitro suggests that the minimal infectious dose may be moderate or low. These factors, together with enforcement of controls prohibiting the use of non-heat treated swill for pig feed will determine the overall risk of exposure of pigs to PRRS-virus via possible, illegal feeding of swill. These factors will in every case be dependant on local conditions and are therefore not readily amenable to a generalised quantitative risk assessment.

The direct consequences associated with the introduction of PRRS are related to the production losses in the individual herd and the number of herds infected. Indirect consequences may include possible measures for prevention and control and restrictions of trade in live pigs, semen and pig meat.

Historically, pig meat from PRRSv-infected countries has been imported into PRRSvfree countries in Europe and New Zealand over the past decade without any evidence of dissemination of PRRSv. In most of these countries strict measures for treatment and disposal of animal waste were in place and this probably contributed significantly to the absence of transmission of PRRSv by that route. Thus, there is to date no documented field evidence to support or quantify the overall risk of importing PRRSvinfected meat. 


\section{Terms of Reference}

\subsection{Background}

Porcine Reproductive and Respiratory Syndrome (PRRS) is a viral disease that is characterised by high abortion rates and mortality in pre-weaned pigs and respiratory disease in fattening pigs. A virus was identified as the major causative agent by the Central Veterinary Research Institute in Lelystad, Netherlands. Since the first isolation, several strains of PRRSv have been recognised.

Besides the viral infection itself and the strain involved, other factors influencing herd immunity such as stress were identified as strong modulators of the disease. Once herd immunity is established, the symptoms are usually non-dramatic or the infection may even remain clinically inapparent. The prevalence of PRRS in the Member States appears to be rather variable between countries and regions. While e.g. Finland continues to remain free of the disease, data from the Loire region of France suggest that around $2.7 \%$ of the holdings are infected. The prevalence among large holdings in other Member States may exceed 50\%.

In the European Union, PRRS is not notifiable or subject to other harmonised disease control measures. However, several third countries, which are free of the disease, apply safeguard measures to protect their herds. International agreements demand that such safeguard measures should be proportionate to the risk involved. However, available data on the prevalence of the virus, its tissue distribution during the different phases of the disease, its degradation during meat maturation, its survival in the environment and other factors influencing the release of the virus are not sufficiently consolidated and evaluated to allow the Commission to draw a clear picture of the risk of virus release. This uncertainty of the risk involved makes any judgement on safeguard measures virtually impossible.

\subsection{Mandate}

The mandate outlined below was accepted by the Panel on Animal Health and Welfare (AHAW) at the Plenary Meeting, on 14 September 2004. It was decided to establish a Working Group of AHAW experts (WG) chaired by one Panel member. Therefore the Plenary entrusted a scientific risk assessment to a working group under the Chairmanship of Dr. Per Have. The members of the working group are listed at the end of this report.

The Commission asks the European Food Safety Authority (EFSA) to assess the risk of transmitting PRRS via fresh pig meat to naive pig populations, which may be exposed to the virus via (illegal) feeding of catering waste (swill) or by other contact with animal waste.

The scientific opinion should address in particular:

- the tissue distribution of the virus during the different phases of the disease

- the likelihood of detection of viraemic or infected pigs at slaughter through ante mortem and/or post mortem inspection

- the reduction of infectivity during maturation, chilling, and freezing of fresh meat 
- the effect on infectivity of certain treatments such as de-boning or removal of lymph nodes

- the likely survival of the virus in catering waste (swill) or in the environment

- the resulting, overall risk of exposure of pig populations to the PRRS-virus via possible, illegal feeding of swill

- the influence of vaccination on the overall risk of transmission of the virus via fresh meat.

This risk assessment is considered for the discussion to establish the relevant conclusions and recommendations forming the scientific opinion by the AHAW Panel.

\subsection{Approach}

According to the mandate of the Panel, ethical, socio-economic, cultural and religious aspects are outside the scope of this risk assessment.

This risk assessment (RA) addressing the risk questions specified by the Commission follows the methodology for RA (which can be summarised as: hazard identification, release assessment, exposure assessment, consequence assessment and overall risk estimation, as defined by the World Organisation for Animal Health (OIE, 2004a).

\subsection{General background information on PRRS}

For the purpose of this risk assessment "fresh pig meat" shall be considered which refers in this particular case to "muscular meat", but also "bone-in meat" although current applicable EU definitions for meat, fresh meat, carcase, viscera and offal are much broader (Council Directive 64/433/EEC (EC, 1964) and EC Regulation No. 853/2004 (EC, 2004). 


\section{Hazard Identification}

\subsection{Description of the disease}

The disease of porcine reproductive and respiratory syndrome (PRRS) was first recognised in 1987 in the United States where it is now widespread and later spread to Canada (Hill, 1990; Keffaber et al., 1992). The first European outbreak occurred in Germany in 1990. The disease was later reported in other European countries, including the Netherlands, the UK and France. PRRS has now become endemic in most major pig producing countries (Dewey, 1998) and represents a widespread problem for pig production with losses due to acute disease estimated to be as much as $€ / \$ 500$ per infected sow (Hoefling, 1990). With a production basis of 20 pigs/sow/year, the impact of the disease in infected herds is therefore very significant. Together with porcine parvovirus, PRRSv represents the most common viral cause of reproductive failure in pigs (Mengeling et al., 2000). The reproductive form of the disease, the respiratory complications, and the impact in growth retardation are usually less severe in endemically infected herds. However, the ability of the virus to persist in convalescent pigs is commonly incriminated in the recurrence of secondary infections in farms affected with PRRSv.

In piglets, infection can result in a dramatic increase in pre-weaning mortality often associated with secondary bacterial infections, for example diarrhoea and greasy pig disease. Piglets may present with breathing difficulties and are in distress. There is a general increase in secondary bacterial infections - diarrhoea and pneumonia.

In growing and finishing pigs, the disease is characterised by a reduction in growth rates, increased mortality (up to $12 \%$ post-weaning), decreased appetite, fever, rough coat, unthrifty pigs, increased respiratory problems, pneumonia and if toxigenic Pasteurella multocida is present, atrophic rhinitis and a general increase in secondary bacterial infections, for example meningitis, greasy pig disease and dysentery.

In breeding stock, there have been many incidences of experimental and field infection when there are no clinical signs at all, perhaps the sows being off their food for a day or so, but no increase in pre-weaning mortality, post-weaning mortality or any disturbance in reproductive problems. The presence of PRRS in such cases can only be detected by serological or virological testing.

In field infections where disease is recorded, reproductive losses and a decreased farrowing rate are a common feature. There is a characteristic rise in early farrowings, at 105 to 112 days, instead of the normal 115 days. There is a corresponding rise in the number of piglets stillborn, mummified or born weak and premature.

The consequence of in utero infection is primarily dependent on the age of the fetus, though the strain of the virus can also play a part, with European strains generally being less pathogenic. Studies by Prieto (Prieto et al., 1996b; Prieto et al., 1997) led them to conclude that exposure of susceptible gilts to PRRSv at the onset of gestation had no significant effects on conception or fertilisation rates, but can result in transplacental infection and occasionally, in fetal death.

PRRSv is now enzootic in most pig-producing countries world-wide and most PRRSv infections in endemically infected breeding pigs are generally sub-clinical. However, in some infected herds, periodic reproductive failure in sows and recurrent respiratory disease problems in nursery and fattening pigs have also been reported (Keffaber et al., 1992; Zeman et al., 1993; Stevenson et al., 1993; Dee and Joo, 1994a; Done and 
Paton, 1995). Veterinarians and farmers have also reported an increase in respiratory disease problems and poor productivity in nursery and fattening pigs since the enzootic appearance of PRRSv (Done and Paton, 1995).

\subsection{Description of PRRS Virus}

\subsubsection{Physical and chemical characteristics}

Since the discovery of porcine reproductive respiratory syndrome virus (PRRSv) as the causative agent of a new reproductive and respiratory disease of pigs in Europe (Wensvoort et al., 1991a) and North America (Collins et al., 1992), it was shown that PRRSv exists as a dynamic group of distinct strains and that although the isolates from North America and Europe shared similar genetic, morphological, physico-chemical, and immunological characteristics, they can be discriminated antigenically (Wensvoort et al., 1993; Yang et al., 1999). Genetic comparison also indicates considerable differences between American and European isolates including deletions as well as point mutations (Meng et al., 1994; Murtaugh et al., 1995). Some strains isolated in North America are closely related to the Lelystad virus (Ropp et al., 2004) and also American strains have been isolated from pigs in Europe some of which are closely related to a vaccine strain (Madsen et al., 1998; Storgaard et al., 1999; Ropp et al., 2004). Genetic and antigenic differences between isolates can have an impact on diagnosis (Yoon et al., 1995a; Magar et al., 1995a), and are associated with variation in disease severity (Halbur et al., 1996b).

PRRSv is a small enveloped single positive-stranded RNA virus. The shared physicochemical properties of the two strains of PRRSv include the presence of an infectious RNA genome of approximately $15 \mathrm{~kb}$ in a proteinaceous nucleocapsid, surrounded by a lipid-containing envelope with five or six structural proteins encoded by the viral open reading frames 2, 2b, 3, 4, 5, and 6 (Meulenberg et al., 1997). Virions are small, pleomorphic spheroids approximately 60-90 nanometres in diameter (Benfield et al., 1992). They are sensitive to lipid solvents and detergents; for example, virus replication is inactivated after chloroform treatment (Benfield et al., 1992).

The European strain of PRRSv appears to be stable for at least 72 hours when chilled at $4^{\circ} \mathrm{C}$ or frozen at $-20^{\circ} \mathrm{C}$, although $93 \%$ of infectivity was lost after storage of the growth medium from infected cultures at $25^{\circ} \mathrm{C}$ for a similar period (Van Alstine et al., 1993). Similarly, studies of the American strain of PRRSv grown in cell culture indicate that PRRSv is stable at $-70^{\circ} \mathrm{C}$ for at least 18 months and at $4^{\circ} \mathrm{C}$ for at least 1 month, while viability is reduced by $50 \%$ after storage at $37^{\circ} \mathrm{C}$ for 12 hours. Complete inactivation of the virus occurred within 48 hours at $37^{\circ} \mathrm{C}$ and by 45 minutes at $56^{\circ} \mathrm{C}$ (Benfield et al., 1992). Bloemraad et al., (1994) determined that the PRRSv half-life in culture medium at $\mathrm{pH} 7.5$ was 140 hours at $4^{\circ} \mathrm{C}, 20$ hours at $21^{\circ} \mathrm{C}, 3$ hours at $37^{\circ} \mathrm{C}$ and 6 minutes at $56^{\circ} \mathrm{C}$. Rapid alterations in $\mathrm{pH}$ decreased the half-life. Bloemraad et al., (1994) concluded that PRRSv is most stable between pH values 5.5 and 6.5. These results concur with those of Benfield et al. (1992) who found that virus infectivity was reduced by over $90 \%$ at a $\mathrm{pH}$ of less than 5 or greater than 7 .

\subsection{Description of PRRS epidemiology}

\subsubsection{Geographical distribution}

As PRRS virus diagnostic technology has been implemented around the world during the 1990s, the virus has been found nearly everywhere domestic pigs are raised. The 
spread between countries has been mainly due to import of infected animals, use of infected semen, or use of modified-live vaccines (vaccine strain introduced).

In some countries, e.g. France, application of systematic control and management measures have maintained a low prevalence (approx. 2\%) of PRRSv infection, at least in some areas (Le Potier et al., 1997).

A few countries continue to remain free from PRRS. In Sweden, Finland, Norway and Switzerland official serosurveys have been carried out since mid-1990' confirming absence of PRRSv antibodies (Elvander et al., 1997; Swedish Board of Agriculture, http://www.sjv.se; National Veterinary Institute, Norway, http://www.vetinst.no, Ministry of Agriculture and Forestry, Finland, http://www.mmm.fi/el/julk/eltauden.html; Swiss Federal Veterinary Office, http://www.bvet.admin.ch.

During the last decade these countries have imported considerable amounts of fresh, chilled or frozen pig meat from EU countries where PRRS is endemic (Table 3-1). 
Table 3-1. Pig and pig meat imports into Sweden, Finland, Norway and Switzerland

\begin{tabular}{|c|c|c|c|c|c|c|c|c|c|}
\hline \multirow{3}{*}{$\begin{array}{c}\text { Indicator } \\
\text { Partner } \\
\text { Product }\end{array}$} & \multirow[b]{3}{*}{ Period } & \multirow{2}{*}{\multicolumn{2}{|c|}{$\begin{array}{c}\mathrm{x} \text { 1,000 Euro } \\
\text { Intra-EU15 }\end{array}$}} & \multicolumn{6}{|c|}{ tonnes } \\
\hline & & & & \multicolumn{3}{|c|}{ Intra-EU15 } & \multicolumn{3}{|c|}{ Extra-EU15 } \\
\hline & & Switzerland & Norway & Sweden & Finland & EU15 & Sweden & Finland & EU15 \\
\hline \multirow{9}{*}{ 0103:LIVE SWINE } & 1995 & & & 0 & 0 & 538.821 & 0 & 2 & 29 \\
\hline & 1996 & 271 & 41 & 0 & 0 & 659.690 & 0 & 0 & 139 \\
\hline & 1997 & 513 & 11 & 0 & 0 & 334.135 & 0 & 0 & 6.491 \\
\hline & 1998 & 399 & 27 & 0 & 0 & 494.301 & 0 & 0 & 1.572 \\
\hline & 1999 & 588 & 2 & 0 & 0 & 608.527 & 2 & 0 & 426 \\
\hline & 2000 & 212 & 0 & 0 & 0 & 634.765 & 0 & 2 & 1.230 \\
\hline & 2001 & 341 & 0 & 0 & 0 & 621.048 & 0 & 6 & 828 \\
\hline & 2002 & 236 & 0 & 0 & 0 & 629.580 & 0 & 11 & 575 \\
\hline & 2003 & 258 & 12 & 0 & 1 & 667.964 & 0 & 3 & 1.020 \\
\hline \multirow{9}{*}{$\begin{array}{c}\text { 0203:MEAT OF SWINE, } \\
\text { FRESH, CHILLED OR } \\
\text { FROZEN }\end{array}$} & 1995 & & & 16.690 & 7.673 & 2.196 .887 & 889 & 0 & 14.434 \\
\hline & 1996 & 28.764 & 8.655 & 17.427 & 10.407 & 2.388.366 & 950 & 0 & 36.828 \\
\hline & 1997 & 34.549 & 3.317 & 19.190 & 8.643 & 2.402 .022 & 567 & 41 & 46.084 \\
\hline & 1998 & 17.861 & 3.369 & 25.100 & 10.522 & 2.727 .212 & 306 & 0 & 37.401 \\
\hline & 1999 & 20.743 & 3.033 & 28.197 & 12.593 & 2.763 .188 & 688 & 170 & 48.459 \\
\hline & 2000 & 25.554 & 3.614 & 40.732 & 12.963 & 2.750 .951 & 768 & 41 & 40.692 \\
\hline & 2001 & 16.867 & 3.133 & 35.004 & 9.160 & 2.986 .575 & 766 & 20 & 45.725 \\
\hline & 2002 & 17.208 & 2.644 & 40.415 & 9.279 & 2.923 .044 & 807 & 31 & 41.297 \\
\hline & 2003 & 22.891 & 4.924 & 43.083 & 7.980 & 3.124 .093 & 983 & 103 & 54.367 \\
\hline
\end{tabular}

Source: EUROSTAT

Table 3.1 shows Pig and pig meat imports into Sweden, Finland, Norway and Switzerland from Intra-EU15 and Extra-EU15.

The Scandinavian countries maintain their freedom from PRRSv by a restricted (by additional guarantees and voluntary controls) and very limited import of live animals and semen without specific restrictions on import of meat. This may indicate a lack of involvement of pig meat in transmission of PRRSv and/or efficient implementation of current and previous national or EU legislation in relation to swill-feeding, i.e. prohibited as of 1 November 2002 (EC, 2001) and strict rules for heat treatment of swill fed to pigs before that (EC, 1980).

Oceania - Serosurveys in New Caledonia (Martin, 1999; Saville, 1999), New Zealand (Motha et al., 1997), and Australia (Garner et al., 1997) found no evidence of infection.

South America - Argentina (Perfumo and Sanguinetti, 2003), Brazil (Ciacci-Zanella et al., 2004), Cuba, and some areas of the Caribbean (Alfonso and Frias-Lepoureau, 2003) reported no evidence of infection.

It should be borne in mind that disease free status may rapidly be lost. In Austria, a 1993 abattoir survey of 253 pigs from 44 herds found no evidence of PRRS virus infection (Nowotny et al., 1994) but clinical outbreaks began in December 1993 (Krassnig et al., 1994). Therefore, ongoing surveillance is required to validate each country's continued PRRS virus-free status.

\section{Conclusion:}

PRRS is widespread in most of the world. Exceptions in Europe are Finland, Norway, Sweden, and Switzerland where active surveillance indicates that PRRS is not present. Likewise, PRRS has not been reported in New Zealand and Australia. Certain countries (e.g. Finland, Sweden, Norway) which have placed controls on importation of live 
animals and semen, yet still import large amounts of potentially infected meat, have not reported any cases of PRRS to date.

\subsubsection{Herd prevalence}

\subsubsection{Monitoring data}

In most countries, PRRS is not a notifiable disease. Therefore, accurate estimates of the prevalence of infection with wild-type virus in specific countries or regions are not readily available. In many cases, published surveys are limited in scope and/or not based on statistically valid population sampling procedures. A larger problem is the fact that, since first introduced into the marketplace in 1994, the widespread use of PRRSv vaccines has compromised the use of serological assays for determining infection status. It is not currently possible to differentiate antibodies against vaccine virus from those induced by field strains of PRRSv.

With these constraints in mind, the best prevalence estimate for the U.S. pig herd is based on a 1995 National Animal Health Monitoring System (NAHMS) study (Anon., 1997). In the 1995 NAHMS study, 8,038 serum samples were collected from 286 herds in 16 swine producing states. Among herds not using modified live virus (MLV) PRRS vaccine, 129 of 217 (59.4\%) herds were infected. Among 6,376 unvaccinated animals, $41.3 \%$ had antibody titres detectable by IFA. When animals were identified by status, $23.5 \%$ of unvaccinated breeding animals and $51.7 \%$ of unvaccinated finishers were IFA positive. The prevalence in different rearing systems may vary, but has been estimated to be between 60 and $80 \%$ at herd level (Zimmerman et al., 1997).

Good prevalence estimates exist for Denmark, because the Danish pig industry maintains a voluntary programme that monitors the status of 3,864 herds in the SPFsystem (SPF=Specific Pathogen Free). The aim of the programme is to prevent the dissemination of certain diseases among herds. Breeding, multiplying herds (genetic herds) and boar units are required to monitor their status by monthly blood testing, while production herds are tested yearly (Mortensen et al., 2001). The SPF programme covers $56 \%$ of the national sow population and about $33 \%$ of the finishing herds. Around $16 \%$ of the SPF herds are positive for the European strain of PRRS whereas only $9 \%$ are positive for the North American type only, whereas $22 \%$ of PRRS are positive for both types and $54 \%$ are negative for both types (Anon., 2005).

Some European countries only have the European strain, whether others like Denmark have both the European and the US strain (introduced by use of vaccine). Even within a country, there might be substantial differences in prevalence. The Danish situation is probably typical of countries with a dense pig population and endemic PRRS.

As examples, Maes (1997) found that 50 of 50 Belgian herds and $96 \%$ of market hogs tested were seropositive. Mateusen et al., (2002) corroborated this earlier study and concluded that PRRS virus was endemic in most farrow-to-finish herds in Belgium. Although PRRS was first reported in Germany in November 1990, Geue (1995) found that 490 of 689 herds $(71.1 \%)$ in the Nordfriesland district of that country were already infected by October 1992. The situation also seems to be true for Asia; Hirose (1995) reported that $46.4 \%$ of animals sampled in 1993 in Chiba Prefecture, Japan, were serologically positive for PRRS virus. In the Republic of Korea, Lu et al., (1999) determined that $87 \%$ of farms (221 of 254$)$ and $59 \%$ of animals $(1,557$ of 2,524$)$ sampled between November 1996 and October 1997 were serologically positive. 
During 2003-2004, 336 Danish SPF pig herds out of around 2424 naive SPF herds got infected with PRRS (Anon., 2005). This means, that in those two years, 14\% of the noninfected herds became infected. This corresponds well with Mortensen et al., (2001) who estimated the annual incidence to be $8 \%$. This corresponds to $15 \%$ over two years $[1-(0.92)(0.92)=0.15=15 \%]$.

\section{Conclusion:}

In PPRSv infected areas with intensive pig production and no specific control measures against PRRS, the prevalence is likely to range between 60 and $80 \%$. In areas of high pig density airborne spread of PRRSv may occur despite good biosecurity measures are in operation.

\subsubsection{Within herd prevalence}

The majority of the herds will either be endemically infected or non-infected, with only a small fraction of herds in a transient acutely infected state at any one point in time. Typically, the herd will experience an acute disease episode lasting 2-4 months (acute phase) followed by a gradual return to normal production (endemic phase) (Christianson and Joo, 1994). The infection usually persists in a herd indefinitely (Albina et al., 1994), unless specific measures are taken to eliminate the infection. A simulation study showed that, without intervention, the average time to extinction in a herd with 115 breeding sows would be 6 years, and 80 years in a herd of twice the size (Nodelijk et al., 2000).

In endemically infected herds, $80-100 \%$ of the piglets will be positive on IFA by $8-9$ weeks of age, although seroprevalence in finishing pigs (5-6 months) may vary from 25-50\% (Dee and Joo, 1994b). A European study among 1,603 infected herds (Mortensen et al., 2001) revealed $83 \%$ of the finishers to be seropositive.

Population density can have a marked effect on the prevalence of PRRS within herds and regions. Even within the same area, larger herds tend to have higher within-herd prevalence relative to smaller herds. For example, serological surveys in Mexico found a high seroprevalence in farms located in the principle swine producing areas and a low seroprevalence in pigs in small, "backyard" herds. In the state of Chiapas (Mexico), Ramirez et al.; (2002) found zero of 80 backyard and feral swine positive for PRRS virus infection. Also a strong trend has been found in Mexico, for virus to be distributed among sows and young pigs on commercial farms (Sierra et al., 2000).

Pigs may become infected either in utero as a result of transplacental infection or at any time postnatal. The most common is postnatal (Mateusen et al., 2002).

In neonatal pigs, maternal antibodies may provide some immunologic resistance to infection. However, the degree of protection is not very well characterized and appears to be of short duration. Under conditions in which susceptible and infectious pigs are mixed, e.g. at weaning, a large proportion of the population may quickly become infected. Dee and Joo (1994b) reported $80-100 \%$ of pigs in 3 swine herds were infected by 8-9 weeks-of-age. In a study of 20 herds, Mateusen et al., (2002) found a seroprevalence of $40 \%$ at 10 weeks-of-age, and that the seroprevalence continued to increase up to 24 weeks of age. This denotes a considerable occurrence of PRRS transmission in the nursery unit. Maes (1997) found $96 \%$ of market hogs sampled from $\mathbf{5 0}$ herds to be positive. 
However, the pattern of infection in PRRS virus-endemic herds often deviates from this description of rapid, uniform spread. For example Dewey et al., (2004) found that in 1 out of 8 farms, only around $12 \%$ of the nursery pigs were infected by the age of 11 weeks. Within infected herds, marked differences in infection rates between groups, pens, or rooms of animals are often observed. Houben et al., (1995b) found transmission to vary even within litters with some littermates seroconverting as early as 6-8 weeks and other individuals as late as 10-12 weeks-of-age. In some cases, litters of pigs reached 12 weeks-of-age, the end of the monitoring period, still free of PRRSv infection. Thus, it is possible for animals in endemically infected herds to escape infection for an extended period of time, as when Le Potier et al., (1997) reported seroconversion in young sows on farms using in-herd gilt replacements. Dee et al., (1996) concluded that the presence of susceptible animals in breeding herds provided a mechanism to maintain persistent viral transmission in chronically-infected farms. The general picture is that PRRS virus infects weaners at an age of 5- to 12 weeks. By the end of the finishing period, most pigs are usually seropositive. For example, Mortensen et al., (2001) found that $83 \%$ of the animals in 1,603 infected herds were seropositive. However, the proportion of infected weaners varies between herds (Dewey et al., 2004).

Chung et al., (2005) monitored pigs from 7 farrow-to-finish continuous pig herds for PRRS. Each herd contained $2,000-2,500$ sows, and about $70 \%$ of the sows were reported to be seropositive. The pigs were monitored every second week from 2 to 22 weeks of age. They were weaned at 4 weeks of age, moved to growing houses at 8 to 9 weeks of age and then to finishing houses at 18 to 19 weeks of age. PRRS virus was isolated from serum collected from 1- to 16-week-old pigs. The highest isolation rates were from pigs 6 to 9 weeks of age. Virus was not isolated from serum when pigs were 22 weeks of age. The infection pattern in the 7 herds was similar; therefore, the results were combined and can be seen in Table 2-2.

Table 3-2. Data on prevalence distribution of PRRS viraemia

\begin{tabular}{|l|l|}
\hline $\begin{array}{l}\text { AGE } \\
\text { (weeks) }\end{array}$ & $\begin{array}{l}\text { Observed } \\
\text { average prevalence }\end{array}$ \\
\hline 2 & $3.3 \%$ \\
\hline 4 & $7.8 \%$ \\
\hline 6 & $55.6 \%$ \\
\hline 8 & $64.4 \%$ \\
\hline 10 & $20.0 \%$ \\
\hline 12 & $5.6 \%$ \\
\hline 16 & $5.6 \%$ \\
\hline 22 & $0.0 \%$ \\
\hline
\end{tabular}

Source: Chung et al., 1997. Table 3-2 shows data observed on prevalence distribution of PRRS viraemia according to age of the pig based on data from 7 herds.

Both live vaccine and field strains of PRRS virus can lead to transplacental infection. Naive sows or gilts exposed to PRRS virus during mid to late gestation are likely to produce piglets that are viraemic at birth as a result of transplacental infection. These piglets provide a source of infection for their littermates and other pigs in the nursery and grower/fattening units.

\section{Conclusions:}


Within herd seroprevalence may vary, dependent on a number of factors including pig density, herd size and husbandry.

PRRS virus usually infects weaners at an age of 5- to 12 weeks, occasionally up to 16 weeks.

By the end of the finishing period, most pigs (around 80\%) are usually seropositive; however, the proportion of infected weaners varies between herds.

\subsubsection{Transmission of PRRS}

In general, PRRS virus is transmitted within a susceptible herd or population at a high rate. Nodelijk et al., (2000) estimated the basic reproduction ratio to be around 3 . It has been postulated that the rate might vary with the viral strain (van der Linden et al., 2003b). Likewise, the rate of transmission is dependent upon the structure and density of the pig producing enterprises in the region (Halbur et al., 1992; Torrison et al., 1994). The primary vector in the transmission is the infected pig (Dee et al., 1994).

Transmission by direct contact has been demonstrated both experimentally (Christianson et al., 1992; Collins et al., 1992) and in field observations, where the spread of PRRS virus by movement of infected stock into susceptible herds has produced epidemic outbreaks (Rossow, 1998). Aerosol transmission of PRRS virus over short distances has been demonstrated experimentally (Torremorell et al., 1997; Wills et al., 1997a; Brockmeier and Lager, 2002; Kristensen et al., 2004) and there are a number of early claims of transmission under natural conditions between neighbouring farms, particularly in conditions of high humidity, low wind speed, and low ambient temperature (Komijn et al., 1991; Edwards et al., 1992; Mortensen and Madsen, 1992) and epidemiological studies of risk factors have also identified positive neighbouring farms as of high risk (Busse et al., 1991; Mortensen et al., 2002).

PRRS virus may be spread by virus-contaminated semen from infected boars (Zimmerman et al., 1993; Yaeger et al., 1993; Swenson et al., 1994b; ChristopherHennings et al., 1995a). According to Hooper et al., (1994) rats and mice are not a reservoir for the virus. Fomites however, do play a role (Yoon et al., 1993; Pirtle and Beran, 1996; Albina, 1997; Dee et al., 2002; Otake et al., 2002). Introduction of susceptible pigs into lorries previously used to carry infected pigs can also result in transmission (Otake et al., 2002). PRRSv has been detected in houseflies from 0 to 12 hours following feeding on a viraemic pig (Otake et al., 2003); however, scarification of the skin of the pig was used to gain access to blood. This makes this route of transmission less likely.

Long-distance transmission can occur as a result of movement of infected pigs or use of contaminated semen. Apart from laboratory studies, there is so far no evidence of introduction of disease via oral transmission of PRRS through uncooked waste of pig meat or pig meat products. A risk assessment performed by the Canadian Food Inspection Agency concluded that neither PRRSv nor TGE presented a hazard when associated with pork or pork products (Farez and Morley, 1997).

The mandate for the present risk assessment concerns the risk of transmitting PRRS via fresh meat to naive pig populations (section 2.2). This could for example occur as a result of trade in pig meat between a country infected with PRRS and a country whose pig population is naive to PRRS. Therefore, the only relevant way of transmission to be dealt with in this risk assessment is through infected pig meat. 
PRRS virus has been isolated from muscles of experimentally infected pigs, primarily in the early stages of infection. However, PRRSv has only seldom been isolated from slaughterhouse pig meat (around 6 out of 1,000 samples), and only at low levels. For a more detailed analysis of the effects of meat maturation, chilling, freezing and subsequent thawing please see chapter 5 . The virus has been demonstrated to be present in meat (Frey et al., 1995; Haynes et al., 1997; Larochelle and Magar, 1997), though, due to it's lability under the conditions of maturation, has not previously been considered to constitute an overt risk (Bloemraad et al., 1994; Farez and Morley, 1997; Amass and Clark, 1999).

\section{Conclusions:}

Long distance transmission of PRRS can occur as a result of movement of infected pigs or by use of semen from infected boars, whereas airborne transmission and mechanical vectors such as mosquitoes and flies will only enable local spread.

Transmission over long distances via infected pig meat remains a possibility and the probability of this occurring under natural conditions is the aim of the present risk assessment.

\subsubsection{Prevention and control}

When the PRRSv was recognized as an emerging disease of significant importance following its first appearance in Europe in the 1990's, actions were taken at the EU level to prevent the spread of the disease and to limit economic losses. However, these proved ineffective and were later abandoned. This was partly due to lack of knowledge of the disease and the way the virus was transmitted.

Today the control is generally based on the implementation of optimal management routines. Herds that are declared free of specific production diseases and follow management programmes to ensure low infection load experience fewer production losses than conventional herds (Anon., 1994; Yoon et al., 2003). In addition specific actions against PRRSv include the strategic use of vaccine and prevention of spread by semen. In endemically infected herds an increasingly common practice is to directly expose pigs to a virulent on-farm isolate in order to protect against re-infection at a later time in life.

PRRSv free herds within endemic infected country can apply biosecurity measures including isolation and testing incoming animals or by limiting contact to herds of the same status.

\subsection{Pathogenesis and Disease Description}

\subsubsection{Clinical signs and gross pathology}

Many descriptions of field disease date from the early and mid 1990s, when the virus was spreading around the globe. More recent descriptions of endemic situations reveal that infection remains inapparent in many herds and productivity seemingly unaffected. Some infected herds report occasional respiratory disease outbreaks in young pigs, or periodic outbreaks of reproductive disease, and a few herds experience severe, chronic disease problems, particularly in young pigs. In these herds, secondary infections with viral or bacterial pathogens, particularly Salmonella choleraesuis, Streptococcus suis or Haemophilus parasuis typically occur concurrently with PRRSv infections (Done and Paton, 1995); 
The clinical signs of PRRS can be extremely variable from pig to pig and from farm to farm (De Jong et al., 1991; White, 1992a, b). In many individual pigs, and even in entire herds, infection can occur without any obvious signs (Yoon et al., 1992b; Morrison et al., 1992a; Robertson, 1992). On some farms, the only indication of infection is an increase in enzootic disease problems in the finishing house (Done et al., 1996). Field reports suggest that quality of management, health status, housing system and quantity of virus present are important factors in this (Robertson, 1992; Done et al., 1996). The factors affecting pathogenesis and clinical effects of PRRSv infection are complex and combinatory, and include the strain of virus, herd health and husbandry and demographics (Goldberg et al., 2000).

Halbur et al., (2002) showed that different strains of PRRS virus have different effects on the blood and bone parameters of experimentally infected pigs, with the most highly pneumo-virulent strains producing a more severe anaemia than the least virulent. When the disease was first recognised in Europe in the 1990's it was frequently called "blue ear disease". Subsequently, the range of clinical signs (frequently vaguely presented by infected animals), was recognised to be wider than blue extremities alone. It is now accepted that such signs occur in only the minority of infected pigs.

\subsubsection{Weaners, growers and finishing pigs}

The typical impact of PRRS in growing pigs is an increase in enzootic disease problems, particularly respiratory disease (Blaha, 1992; Done et al., 1992). Occasional pigs may be underdeveloped with white or yellow skin.

Others may suffer an influenza-like illness and pneumonia, directly attributable to PRRS virus. In a US study of 45 cases of weaner pneumonia, PRRS virus was involved in 21 of them (Halbur et al., 1993). Other pathogens involved were swine influenza virus, pseudorabies virus, porcine respiratory coronavirus and porcine paramyxovirus plus some unknown agents. Of the 21 PRRS infected herds, 11 had a history of sow reproductive problems in the previous two years. After inoculation of PRRS virus isolates into 4-8 weeks old pigs, some isolates produced barely detectable respiratory disease while others produced moderate disease of short duration while yet others cause persistent respiratory disease with thumping, lasting more than two weeks. Some isolates produce encephalitis, myocarditis and splenomegaly. Variation in effects could be due to strain differences or to the presence of more than one agent in an inoculum.

In a 500 sow farrow-to-finish unit in the U.S.A., weaning at 3-4 weeks, weaner mortality averaged $3.1 \%$, before an acute PRRS outbreak, and $7.4 \%$ (fluctuating from $3-16 \%$ ) in the 34 months afterwards (Stevenson et al., 1993). Deaths were mainly at 2-3 weeks after weaning and were higher in the winter. Affected pigs were initially lethargic and developed anorexia and cyanosis of extremities after 12-24 hours. Subsequently there was dyspnoea and death. Another farm, twice as big, was similarly affected. Both PRRS virus and Salmonella choleraesuis were isolated from the affected pigs.

In a German study, morbidity and mortality data for 12 herds of fattening pigs are provided, before and after PRRS infection of the source breeding herds (Chung et al., 2005). Average mortality was reported to have increased from $2.2 \%$, before PRRS epidemic, to $4.3 \%$ three months after infection and $2.8 \%$ eight months after infection. In particular, mortality was increased in herds with higher pre-epidemic mortality. The average frequency of lung lesions at slaughter increased from $45 \%$ before PRRS to $70 \%$ in pigs born during and after PRRS in the breeding herds. This study also 
confirmed that the consequences of PRRS are more severe in herds with lower standards of hygiene and management. The effect of PRRS on respiratory disease was attributed to the reduction of lung macrophages. These workers also postulated this as the reason for the occurrence of Pasteurella and Actinobacillus spp. in septicaemic form rather than the usual localisation in the lungs.

\subsubsection{Breeding herds}

Data concerning the prevalence of clinical effects in breeding herds experiencing acute PRRS outbreaks are summarised in Table 3-3. The influenza-like illness often appears first on affected farms and pigs may show conjunctivitis, depression, lethargy and inappetence lasting a few days or, in some cases, as long as two weeks. Only a proportion of the pigs are affected at one time, usually a small percentage, but the affected animals vary from day to day, leading to the description of "rolling inappetence".

Adult pigs occasionally show respiratory symptoms such as laboured breathing or coughing but these symptoms are more common in young pigs (possibly because of secondary infections). Young pigs may show coughing, sneezing, dyspnoea, abdominal breathing, conjunctivitis, neonatal diarrhoea and facial oedema (Done et al., 1996). These signs may result from secondary infections in addition to primary effects of PRRS virus.

Table 3-3. Acute PRRS: Clinical signs and effects

\begin{tabular}{|c|c|c|}
\hline Clinical sign or effect & $\%$ of farms affected & $\begin{array}{l}\% \text { of animals affected } \\
\text { on affected farm }\end{array}$ \\
\hline \multicolumn{3}{|l|}{ Primary influenza-like illness } \\
\hline Fever & 50 & $1-10$ \\
\hline Blue extremities & 69 & $1-5$ \\
\hline \multicolumn{3}{|c|}{$\begin{array}{l}\text { Also: inappetence, conjunctivitis, eyelid oedema, depression, respiratory signs, haemorrhage, } \\
\text { bruising }\end{array}$} \\
\hline \multicolumn{3}{|l|}{ Secondary effects } \\
\hline Pre-weaning mortality & 100 & $10-40$ \\
\hline Post-weaning mortality & 100 & $1-10$ \\
\hline Sudden death & 44 & $1-2$ \\
\hline Pneumonia (growers) & 50 & $1-30$ \\
\hline \multicolumn{3}{|l|}{ Reproductive effects } \\
\hline Abortions & 44 & $1-2$ \\
\hline Premature litters & 100 & $1-20$ \\
\hline Stillborn piglets & 100 & $7-35$ \\
\hline Returns to service & 69 & $10-50$ \\
\hline
\end{tabular}

Source: (Meredith, 1995a,b)

Most pigs, particularly finishing or adult pigs, recover from the uncomplicated primary mild illness although some young pigs continue to show poor growth rates and stunting subsequent to clinical recovery. A small proportion of affected pigs of any age may show more serious signs of fever or subnormal temperature.

In a U.K. survey, skin changes occurred in 1-2\% of sows in the form of hyperaemia or cyanosis of extremities (ears, tail, teats, vulva, and limbs), pooling of blood within the skin (particularly at pressure points) and intradermal haemorrhage (White, 1992a, b). 
The skin changes usually developed 5-7 days after onset of illness, but sometimes affected pigs show no other symptoms. Cyanosis of ears has, as mentioned earlier, led to the popular, if inappropriate, name of "blue ear disease" in Europe. Discoloration of the extremities is, however, an uncommon sign, reputedly more marked in cold climatic conditions. Sometimes it leads to necrosis of the affected tissue. In some pigs, discoloration may appear without any other signs of illness. Discoloration can be very transient, disappearing within a few hours.

The initial episode illness in sows is often followed by an outbreak of abortions, premature farrowings and mummified fetuses plus outbreaks of secondary infections, principally in growing pigs. In fattening pigs, the pattern of morbidity and mortality appears to be dependent on the prevailing secondary infections on the farm (Chung et al., 2005). Abortions may affect about $2 \%$ of pregnant sows and have often been reported to occur late in pregnancy (Mengeling et al., 2000). Loss of condition in sows that are inappetent can lead to anoestrus.

The abortions and premature farrowings result in a high prevalence of stillbirths, neonatal deaths and weakly (including "splay-legged") piglets. Neonatal piglets occasionally show a "domed" skull and oedema of the eyelids. Stillborn piglets may be freshly dead (intra-partum deaths) or die pre-partum. In the later stages of an outbreak, "mummified" piglets are also born. In an early report of the clinical impact in Germany, Vogel et al., (1991), found that the percentage of sows farrowing at up to 112 days of gestation rose from $7.5 \%$ to $30 \%$ for a period of six weeks.

Apart from the acute reproductive effects of the disease there can also be infertility in both sows and boars and loss of milk production in some sows. Boars can show the same clinical signs as sows: anorexia and possibly fever or cough. An increased number of both regular and irregular returns may be seen (Thacker, 1992). Semen can transmit infection (Yaeger et al., 1993) and quality is also affected, revealing a significant decrease in sperm motility and in spermatozoa with normal acrosomes (Prieto et al., 1996a). Effects on quality have been estimated to last for up to 13 weeks. In a US study of six PRRSv-inoculated boars (Wasilk et al., 2004), peak levels of viraemia were seen at 5 days post inoculation (DPI) and were consistently detectable throughout 22 DPI. In five of six boars, PRRSv was shed in semen for 0 to 2 days during the first $10 \mathrm{DPI}$; however, one of six boars shed the virus in semen through 32 DPI.

\section{Conclusions:}

In summary, therefore, the clinical signs and pathology of acute PRRS are unlikely to be missed at a herd and regional level, when occurring in a previously free area. In the case of endemic PRRS clinical and pathological signs are less obvious and can easily be missed.

Given that the clinical signs and gross lesions can be variable or absent at individual and herd level, detection of disease by ante and post mortem examination at slaughter is unreliable.

\subsubsection{Pathogenesis}

In vitro, PRRSv replicates only in a limited number of cell types. Of many swine cell types, only pulmonary alveolar macrophages (PAMs) and aged blood monocytes support a productive replication of PRRSv. Despite the fact that PAMs are the most sensitive cell type for PRRSv, these cells show some restriction to a PRRSv infection 
when they are freshly isolated. The susceptibility clearly increases after one-day cultivation, suggesting that the state of monocyte/macrophage differentiation plays an important role in determining their susceptibility to PRRSv (Duan et al., 1997a). PRRSv can also be cultivated in three established non-porcine cell lines: MARC-145 (Kim et al., 1993) and CL-2621 cells (Benfield et al., 1992), both originating from the embryonic monkey kidney cell line MA-104, and CRL-11171 cells (Meng et al., 1996). It has been reported by several authors that the susceptibility of the different cell types differs among strains. Bautista et al., (1993) demonstrated that, when using PAMs and CL-2621 cells, nearly one third of PRRSv isolates grown in one cell type failed to grow in the other one.

PRRSv entry in macrophages occurs via receptor-mediated endocytosis and two PRRSv receptors have been identified on alveolar macrophages (Delputte et al., 2002; Delputte and Nauwynck, 2004). A first PRRSv receptor was identified by generation of two monoclonal antibodies (Mabs), which were able to block PRRSv infection (Duan et al., 1997b). A protein with a molecular weight of approximately 210-kDa was precipitated by these Mabs. This protein was recognised as the porcine homologue of mouse and human sialoadhesins (Vanderheijden et al., 2003). Delputte et al., (2002) showed that addition of heparin or heparan sulfate, or heparinase treatment of alveolar macrophages, clearly reduced PRRSv infection, indicating that PRRSv binds to cell surface heparan sulfate glycosaminoglycans. Recent data showed that the attachment of PRRSv to its host cell is initiated by an unstable binding of the virus to heparan sulfate glycosaminoglycans and is finalized by a stable binding of the virus to sialoadhesin (Delputte et al., 2005). Following binding to the cellular receptors, virus particles become internalized by a microfilament-dependent process through small clathrin-like coated vesicles. During this stage, an acidic $\mathrm{pH}$ is required to trigger fusion between the viral envelope and the endosomal membrane allowing the viral nucleocapsid to enter the cytoplasm for replication (Nauwynck et al., 1999). Newly produced viral antigens are detected within the cytoplasm of alveolar macrophages as soon as 6 hours after inoculation. From this time on, the nucleocapsid buds at the smooth endoplasmatic reticulum (Pol et al., 1992). Virions seem to mature between the endoplasmatic reticulum and the Golgi apparatus, since budding and accumulation of enveloped virus particles can only be observed between these organelles (Dea et al., 2000). PRRSv may be released by exocytosis or by cell lysis. One replication cycle of PRRSv takes about 9 to 12 hours (Pol et al., 1992). Cytopathic effect is visible after 24 hours (Paton et al., 1992a; Bloemraad et al., 1994). The exact mechanism of cell death is still not completely resolved, but is likely to be through apoptosis (Labarque et al., 2003; Miller and Fox, 2004). An early report that the GP5 protein of the virus, encoded by ORF5, has been shown to induce apoptosis in vitro (Suarez et al., 1996), has recently been brought into some doubt (Lee et al., 2004) 
Figure 3-1. Course of viral load indifferent pig tissues

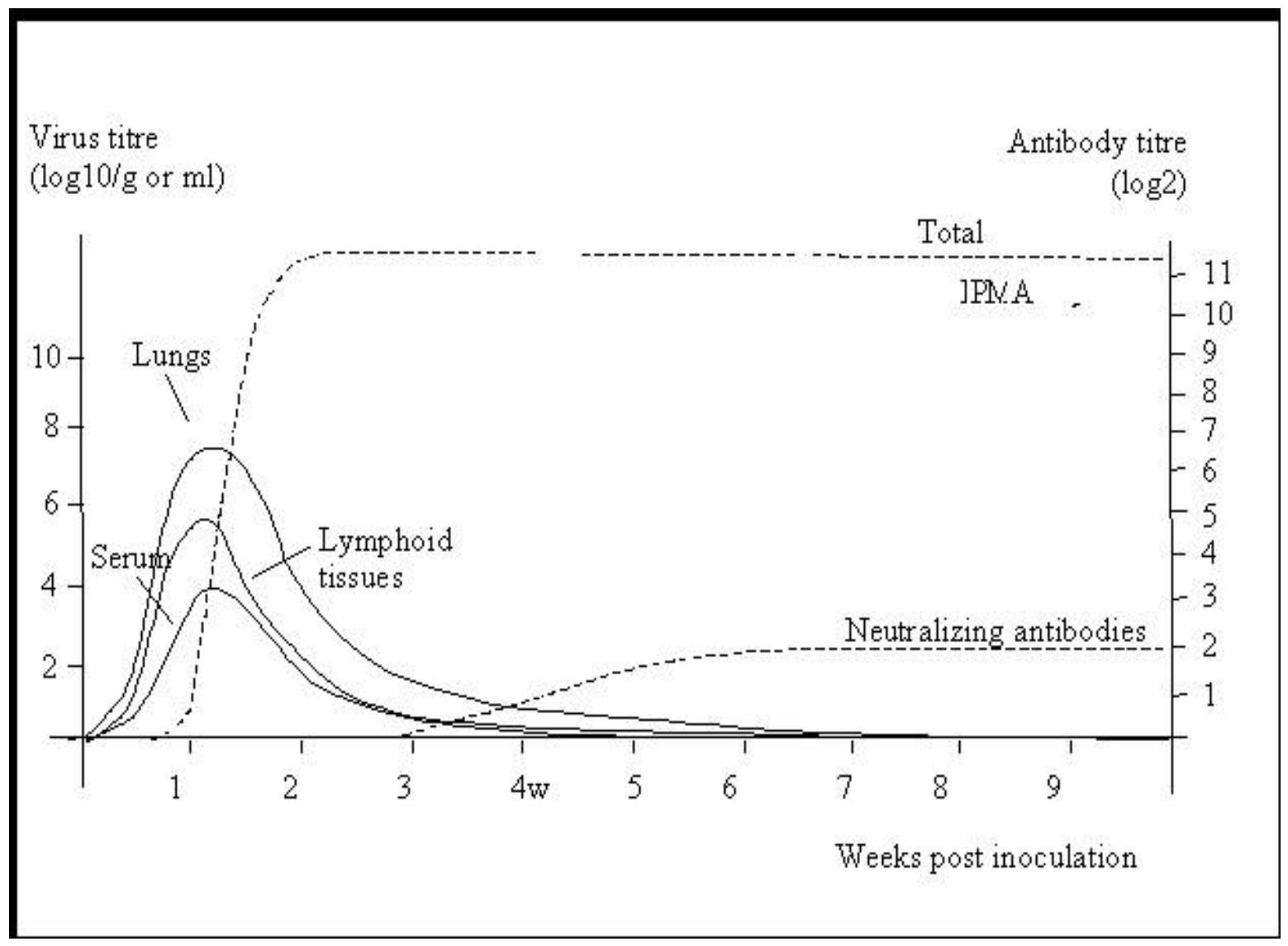

Figure 3.1. is based on Duan et al., (1997b) and Labarque et al., (2000) ${ }^{1}$ and shows the course of viral load in lungs, lymph nodes and serum and humoral immunity upon inoculation of Lelystad Virus (European prototype of PRRSv).

In vivo, pigs of all ages are susceptible to a PRRSv infection. Experimental infection can be achieved following intranasal, intratracheal, oronasal, oral, intramuscular, intrauterine, intravenous, or intraperitoneal inoculations (Wensvoort et al., 1991a; Christianson et al., 1992; Collins et al., 1992; Christianson et al., 1993; Wills, 1994; Rossow et al., 1994a; Swenson et al., 1994a; Pol et al., 1997; Van Reeth et al., 1999; Yoon et al., 1999). Under natural circumstances, the virus most frequently enters via the respiratory tract, but viraemia and dissemination throughout the body rapidly occur. The kinetics of a PRRSv infection in the lungs and lymphoid organs (see Figure 3-1) have been described in detail by several authors (Duan et al., 1997b; Beyer et al., 2000; Labarque et al., 2000). In these studies, inoculation with PRRSv rapidly resulted in viraemia and virus replication in several organs. From 2 to 4 days after inoculation onwards, it was possible to isolate PRRSv from lungs, tonsils, lymph nodes, thymus, spleen and blood. The highest virus titres in tonsils and lungs were reached at 9-14 days after inoculation, whereas the highest virus titres in lymph nodes were reached at 3 days after inoculation. From tonsils, lymph nodes and thymus, virus isolation was possible up to 21 days after inoculation; from lungs infectious virus was recovered until

\footnotetext{
${ }^{1}$ The figure is representative of infection of naïve animals and the course may be modulated by maternal antibodies.
} 
35 days after inoculation. PRRSv-infected cells were mostly located in the alveolar spaces of the lungs and in germinal centres of lymphoid follicles in lymph nodes and spleen. Cell-free viraemia was detected until 21 to 28 days after inoculation. The latter finding was confirmed by other groups (Halbur et al., 1996a, b; Wills et al., 1997b). However, extended periods of viraemia, of up to 5-9 weeks duration has also been reported (Yoon et al., 1993; Bilodeau et al., 1994; Sur et al., 1997). During viraemia, the virus may be distributed to various organs. The course of infection may be modulated by age at infection and maternal immunity. PRRSv can be detected in muscle in $60 \%$ of infected animals with peak titres at day 11 of between $10^{3.3}$ and $10^{4.3} \mathrm{TCID}_{50} / \mathrm{g}$, with a detection limit of $10^{1.8} \mathrm{TCID}_{50} / \mathrm{g}$ (Steverinck, 1999). In boars, the virus may infect the male reproductive tract and be shed in semen (Swenson et al., 1994b; Christopher-Hennings et al., 1995a). In pregnant sows, PRRSv is able to cross the placenta. However, the efficiency by which PRRSv crosses the placenta depends on the stage of gestation. At early- and mid-gestation, transplacental infection is rarely observed (Christianson et al., 1993; Mengeling et al., 1994). However, during late gestation (93 days of gestation), transplacental infection occurs easily (Christianson et al., 1992). These differences may be explained by differences in placental permeability during gestation (Christianson et al., 1993). The virus has further been detected in nasal turbinates, kidneys, brain, liver, trachea, lymph node, bone marrow and choroid plexus (Pol and Wagenaar, 1992; Rossow et al., 1994b; Rossow et al., 1995; Beyer et al., 2000).

Cells of the monocyte/macrophage lineage are the main target cells for PRRSv. The susceptibility of these cells to PRRSv varies, however, in different organs. Macrophages in lungs, tonsils, lymph nodes and spleen are permissive to PRRSv infection (Thanawongnuwech et al., 1997; Duan et al., 1997a; Duan et al., 1997b; Beyer et al., 2000), whereas virus infection was not detected in macrophages of liver, kidneys and heart, or in macrophage precursor cells such as blood mononuclear cells and bone marrow cells (Duan et al., 1997a; Duan et al., 1997b). Virus replication has also been shown in microglial cells (Molitor et al., 1996). It is remarkable that only $2 \%$ of the alveolar macrophages, which are the main target cells in vivo, become infected, even at the peak of virus replication in the lungs (Mengeling et al., 1995; Duan et al., 1997b). Thus, PRRSv appears to have a preference for certain subsets of macrophages in vivo. A number of publications have described the observation of PRRSv antigens in a low number of epithelial cells in bronchi (Pol et al., 1991), of epithelial cells in the nasal mucosa (Rossow et al., 1996), of type II pneumocytes (Pol et al., 1991; Halbur et al., 1994a; Rossow et al., 1995) and of endothelial cells (Halbur et al., 1995; Halbur et al., 1996a). In contrast to these findings, Duan et al., (1997b) and Beyer et al., (2000) did not observe PRRSv antigens in these cell types. Since macrophages are ubiquitously distributed cells that display a variety of morphological phenotypes (Rutherford et al., 1993), it is possible that the viral antigen-positive epithelial and endothelial cells may actually represent monocytes/macrophages during their migration through tissues. Indeed, Teifke et al., (2001) and Howerth et al., (2002) have recently ruled out the previously postulated role of epithelial and endothelial cells in the replication of PRRSv.

Virus persistence: A particular feature of PRRSv is its capacity to persist for long periods of time after initial infection. Evidence for persistence came from several publications. Virus transmission by direct contact between susceptible pigs and pigs infected 8 to 16 weeks earlier have been reported (Zimmerman et al., 1992; Bilodeau et al., 1994; Albina et al., 1994; Bierk et al., 2001; Wills et al., 2002). There is some conflicting data about the exact duration and site of PRRSv replication during the persistent stage. In our opinion, detection of infectious virus, either by virus isolation or 
swine bioassay, is required to definitively classify animals as persistently infected. In studies by Duan et al., (1997b) and Beyer et al., (2000), lungs and alveolar macrophages were the only tissues in which PRRSv was persistently detected for 35 days after inoculation. Further evidence for virus persistence in pulmonary macrophages has been obtained by Shibata et al., (1997) and Mengeling et al., (1995). They demonstrated that alveolar macrophages obtained by broncho-alveolar lavage were virus-positive up to days 49 or 70 after inoculation. Other studies also suggest persistence of infectious PRRSv in lymphoid organs, especially in the tonsils. Rossow et al., (1994b) could isolate PRRSv exclusively from tonsils, spleen and lymphoid tissues and not from the lungs at $\mathbf{2 8}$ days after inoculation. Further, PRRSv could be isolated from tonsil homogenates until 84 (Allende et al., 2000) to 105 (Horter et al., 2001) days after inoculation. Wills et al., (1997b) reported that infectious virus was isolated up to 157 days post infection from oropharyngeal swabs, these authors also highlighting that such samples are ill-defined and could consist of blood traces, epithelial cells, saliva, lacrimae, nasal secretions and respiratory tract secretions.

PRRSv is also able to persist in the reproductive tract of boars. Swenson et al., (1994b) detected infectious virus in the semen of experimentally infected boars for as long as 43 days following exposure. Using the polymerase chain reaction (PCR), viral RNA in semen has been detected until 92 days after inoculation (Christopher-Hennings et al., 1995b). A polymerase chain reaction was used for detecting viral RNA in semen, because virus isolation on semen is troublesome (Christopher-Hennings et al., 1995b). PRRSv has been detected in the bulbo-urethral gland until 101 days after inoculation (Christopher-Hennings et al., 1995b) or in testes until 25 days after inoculation (Sur et al., 1997). The major source of PRRSv in semen is thought to be within virus-infected monocytes/macrophages or non-cell-associated virus in serum, rather than via the spermatozoa (Christopher-Hennings et al., 1998). This is supported by a recent study of viral distribution in testis using in situ hybridisation (Shin and Molitor, 2002) which revealed presence of virus in seminiferous tubules, but at very low amounts, leading these authors to suggest that the testes themselves are not a major source of virus during extended seminal shedding. Interestingly, these authors also demonstrated abundant hybridization positive signals in the brain stem and tracheobronchial lymph node 7 days post-infection.

\subsubsection{Immunity}

PRRSv-infected pigs develop a humoral immune response that can easily be detected by the presence of serum antibodies to the virus. Most serologic assays indicate that antibodies appear at 1 to 2 weeks after infection, reach a maximal titre by 5 to 6 weeks and persist for 42 weeks. Both immunoglobulins $M$ and $G$ are involved in the specific humoral immune response to PRRSv. IgM antibodies are first detected at day 7 , peak at 14 to 21 days and rapidly decrease, being undetectable by 35 to 42 days. IgG antibodies appear by day 11 to 14 after infection, peak at 21 to 28 days and are detectable for several months (Loemba et al., 1996; Vezina et al., 1996; Labarque et al., 2000). Antibodies with a virus-neutralizing activity appear more slowly. They are usually detected first at 4 to 6 weeks after infection and reach a maximal titre about 10 to 12 weeks after infection (Morrison et al., 1992b; Yoon et al., 1995b; Loemba et al., 1996; Molitor et al., 1997a; Albina et al., 1998b; Labarque et al., 2000; Delputte et al., 2005).

Meier, (2000) detected virus-neutralizing antibodies not earlier than 11 to 13 weeks after infection. The appearance of neutralizing antibodies coincides with the final elimination of the virus (Labarque et al., 2000; Delputte et al., 2005). 
Little is known about the cellular immune response to a PRRSv infection. Bautista and Molitor, (1997) and Lopez Fuertes et al., (1999) demonstrated a clear T lymphocyte proliferation to PRRSv. This T lymphocyte proliferation was first detected at 4 weeks after infection, peaked at 7 weeks and appeared to decline after 11 weeks. The proliferation involved mainly CD4+ T lymphocytes, but also CD8+ T lymphocytes. An elevated level of CD8+ T lymphocytes from 3 to 5 weeks after infection has been demonstrated by several researchers (Shimizu et al., 1996; Albina et al., 1998a, b; Janutenaite et al., 2002). The biological significance of this change in CD8+ cell numbers is not clear, but in the study of Albina et al., (1998a), viraemia started to decline shortly after the proliferation of these CD8+ cells. Bautista et al., (1999) demonstrated that the $\mathbf{T}$ lymphocyte proliferation response was largest after stimulation with the product of open reading frame 6 , suggesting that the matrix protein $(M)$ is specifically recognized by $T$ lymphocytes from PRRSv-infected pigs. In another study performed by Meier et al., (2002), T lymphocyte proliferation was first detected at 3 weeks after infection and appeared to increase steadily from 11 to 13 weeks. The latter authors also reported that the frequency and quality of a $T$ lymphocyte-mediated IFN-y response, as detected by ELISPOT, was low and very poor during the first 9 to 10 weeks after infection.

\section{Conclusion:}

PRRSv replication reaches a maximum during the first two weeks after inoculation with virus titres up to $10^{7-8} \mathrm{TCI} \mathrm{D}_{50} / \mathrm{g}$ in lungs, up to $10^{5-6} \mathrm{TCI} \mathrm{D}_{50} / \mathrm{g}$ in lymphoid tissues and $10^{3-4} \mathrm{TCID} \mathrm{D}_{50} \mathrm{~g}$ in serum and muscle. The onset of the specific immunity results in a reduction of virus replication between the third and sixth week after inoculation, leading in general to a full elimination of the virus.

PRRSv can persist in certain, specific tissues for prolonged periods following acute infection. These tissues include tonsil and certain other lymphoid tissue, and also lung and other pulmonary sites. The semen of infected boars can also yield virus for extended periods. There is no evidence of extended viraemia or recrudescence following viral clearance.

\subsubsection{Specific virus degradation during meat maturation, chilling, freezing} etc.

According to Beutling, (1992), a rapid reduction of the $\mathrm{O}_{2}$ concentration within the muscles of the slaughter pig occurs after bleeding. The bleeding process itself has a duration of 7-10 sec. The resynthesis of adenosintriphospate (ATP) in muscles stops. The remaining ATP will be decomposed to ADP and finally AMP (adenosinmonophospate). The energy from this process is used for the anaerobic glycogenolysis. Lactic acid as an end product is enriched in the muscles accompanied by $\mathrm{pH}$-decrease. Because of the lack of ATP the contraction of the muscle fibres results in rigor mortis. The rigor is reversed by enzymes in the muscle, especially proteases and hydrolases. The time lapse cannot be defined exactly as it is dependent mainly on the original glycogen content (reduced e.g. by stress, shock or disease) and temperature.

The maturation process "sensu stricto" comprises different postmortal factors including glycolytic enzymes and proteases. Maturation comprises acidification, aroma, tenderness, colour and the increase of the content of meat juice. The postmortal glycolysis leads to an enrichment of lactic acid and thus to an acidification of the muscle tissue $\mathrm{pH}$ from neutral values of $6.8-7.2$ to "final $\mathrm{pH}$ values" of $5.3-5.8$. From meat quality aspects acceptable values are also ranging from $5.8-6.2$ after $24 \mathrm{~h}$ 
after slaughter. An overview is given in table 3-4. The values are standardised for measurement in the Musculus semimembranosus and can vary in a narrow range at other points of measurement. During the maturation process with proteolysis the $\mathrm{pH}$ will increase over time, therefore no definitive final $\mathrm{pH}$ can be given.

Abnormal $\mathrm{pH}$ values after slaughter in pigs can occur following a PSE syndrome (pale, soft and exsudative meat). Depending on the breed and transport stress such a syndrome can lead to a dramatically accelerated glycolysis. These results in a $\mathrm{pH}$ value 45 min. after slaughter of $<5.8$ (normally $>6.5-6.8$ ) and meat quality deficiencies. The final $\mathrm{pH}$ after $24 \mathrm{~h}$ does not differ from normal values (i.e. 5.3 - 5.8) (Honikel, 1996) (Table 3-4.)

The minimum time requirement for the full maturation process for pigs is $60 \mathrm{~h}$ (Wheeler et al., 2000). Data for the different components of the carcass are not available, $\mathrm{pH}$ is normally measured solely in the muscle. Temperature requirements include all parts of the carcass including bones. De-boning has no effect on muscle $\mathrm{pH}$ or temperature.

Table 3-4. pH-values in pig meat

\begin{tabular}{|l|l|}
\hline Status & pH-value \\
\hline $\begin{array}{l}\text { Pig/normal slaughter } \\
\text { status }\end{array}$ & $5.3-5.8 *$ \\
\hline $\begin{array}{l}\text { Deviation with PSE } \\
\text { syndrome }\end{array}$ & $<5.8 * *$ \\
\hline tolerable values & $5.8-6.2 *$ \\
\hline
\end{tabular}

*: pH24: measuring $24 \mathrm{~h}$ after slaughter; **: pH1: measuring $45 \mathrm{~min}$. after slaughter Table 3-4. shows normal and abnormal pH-values in pig meat measured in $M$. semimembranosus (acc. to Reuter, 1996).

The initial carcass temperature after slaughter is $39-42^{\circ} \mathrm{C}$ because of anaerobic glycolysis and technological processes (Beutling, 1992). Temperatures below $10^{\circ} \mathrm{C}$ can be reached after few hours; however different commercial systems of cooling are applied where temperatures below $30^{\circ} \mathrm{C}$ are reached after $6 \mathrm{~h}$ and below $10^{\circ} \mathrm{C}$ after approx. 19-20h. According to legal requirements pig carcasses must reach $7^{\circ} \mathrm{C}$ before moving the carcass (EC, 2004). This is normally achieved within $12 \mathrm{~h}$ after slaughter, but should be reached at the latest within $24 \mathrm{~h}$ to avoid maturation defects (Beutling, 1992; Savell et al., 2004). Chilling pig meat to internal temperatures of 20 to $25^{\circ} \mathrm{C}$ within 2 to $3 \mathrm{~h}$ post-mortem can reduce PSE. Different cooling systems are commercially applied, whereby the time needed to reach a core temperature of the carcass of $7^{\circ} \mathrm{C}$ ranges from $12 \mathrm{~h}$ with fast cooling systems to $1.5 \mathrm{~h}$ with shock cooling/intensive cooling systems (Ortner, 1988; Beutling, 1992). Too rapid chilling can affect quality (Savell et al., 2004). Figure 3-2 below shows a typical chilling process of a commercial abattoir. Other abattoirs might apply a temperature of $-22^{\circ} \mathrm{C}$ which would result in a steeper temperature curve in the initial phase. 
Figure 3-2. Core temperatures in different parts of the pig carcass

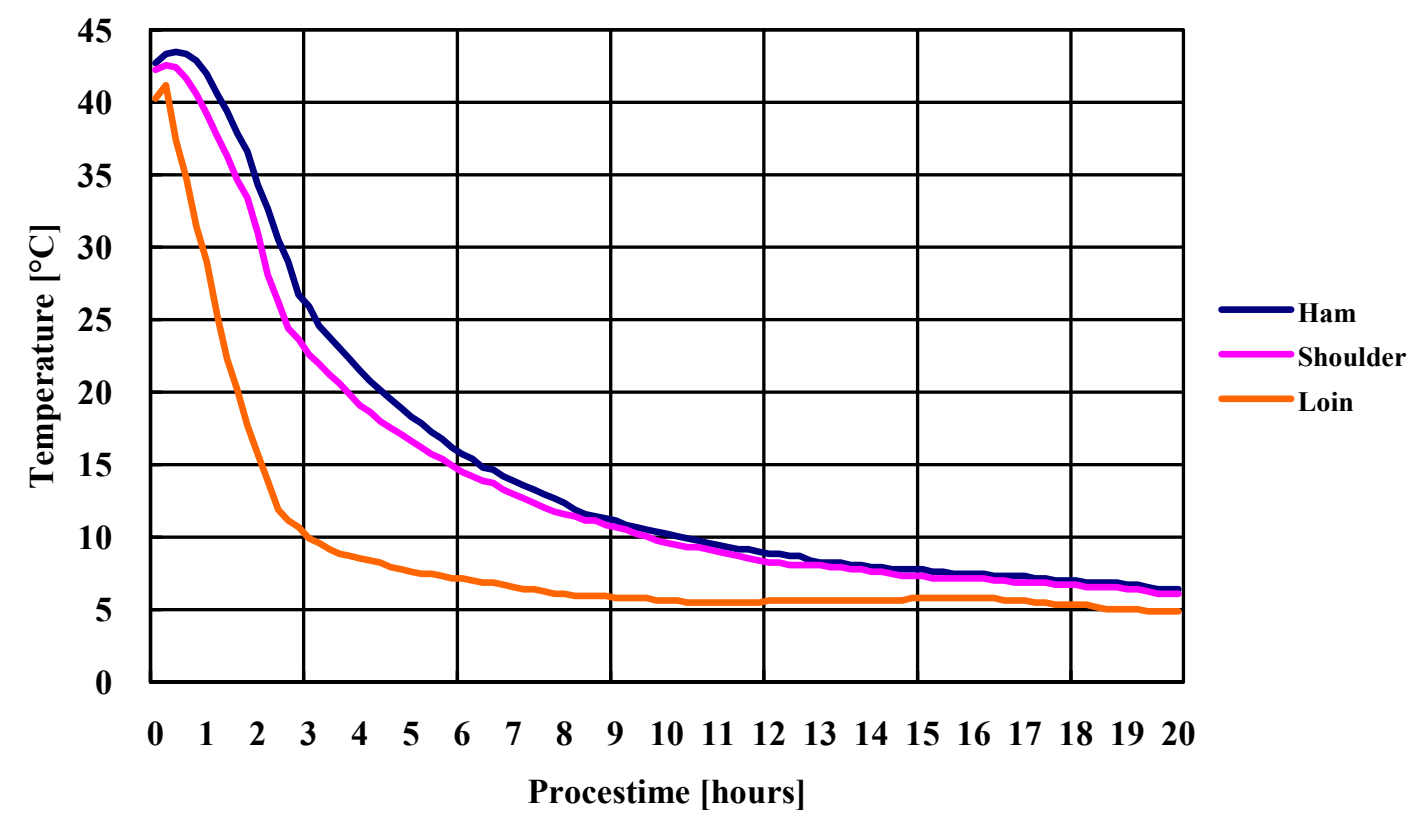

Figure 3.2 shows the core temperatures in different parts of the pig carcass of $75 \mathrm{~kg}$ (including head) during a typical chilling process, using an air flow with a temperature of $-18^{\circ} \mathrm{C}$ at a velocity of $4.0 \mathrm{~m} / \mathrm{s}$ for the first 80 minutes. Typical weight loss would approximate 1-2\%. (DMRI, Danish meat research institute).

Pigs have normally an amount of $65 \mathrm{ml}$ blood per $\mathrm{kg}$ body weight ranging from 60 to $75 \mathrm{ml}$. A slaughter pig with about $100-120 \mathrm{~kg}$ weight has therefore a blood content of 6.5 to $7.3 \mathrm{I} .60 \%$ of the blood is lost at sticking and bleeding and $20-25 \%$ remain in the viscera. A maximum of $10 \%$, normally between 1-2 \% can be found in the carcass muscles (2-9 $\mathrm{ml}$ per $\mathrm{kg}$ muscle). In the case of insufficient bleeding (bleeding during circulatory collapse or technical failure) this amount can be higher, especially in the viscera (Warris, 1984) resulting in a higher $\mathrm{pH}$ in the muscle and viscera near neutral values.

There are no known legal requirements for maturation despite temperature regulations (muscle meat must be stored and transported at maximum $7^{\circ} \mathrm{C}$, viscera at $\left.3^{\circ} \mathrm{C}\right)$.

There are no harmonised agreements or legislation governing the treatments applied to the maturation process. Generally speaking, the meat industry regards it as desirable that chilling to refrigeration temperature is achieved as quickly as possible, though the efficiency of such will vary.

Legislation concerning storage and transport is harmonised throughout the European Union by the EC regulation No 853/2004 (EC, 2004) connected with the inhibition of growth of food-borne bacterial pathogens.

The association of PRRSv with lymphoid tissue has been extensively reviewed in section 3.4.2 of this report. Visible lymph nodes can be removed during the trimming process but this is done not necessarily and not systematically. Lymph nodes in locations not accessible during slaughter (within groups of muscles or viscera) will not 
be removed. The proportion of lymphoid tissue in fresh meat cannot be quantified. In whole carcasses most of the body and cephalic lymph nodes can be present. The major caudal lymph nodes of the carcass like Lnn. iliaci med. and lat. and Lnn. ileofemoralis may have been removed, but there is no requirement to do so. The lymph nodes located inside the carcass will always be present. Sternal lymph nodes will regularly be present under commercial circumstances as well as other lymphoid tissues like lymph nodes located inside the carcass between muscles etc. Deboned meat and slices will normally not contain lymph nodes themselves, as they are removed with the surrounding connective tissue. Lymphoid tissue like vessels inside the muscles cannot be removed.

The occurrence, preservation, and degradation of PRRSv have been examined by several researchers. PRRSv has been isolated from muscle of experimentally infected pigs and rarely from slaughterhouse pig meat (data summarised in table 3-5). Bloemraad et al., (1994) found that low levels of PRRSv were recovered from muscle of experimentally infected viraemic pigs slaughtered 5 and 10 days after infection. PRRSv was isolated from some samples of muscle 0 and 24 hours after slaughter $\left(10^{2.8}-10^{3.7} \mathrm{TCID}_{50} / \mathrm{g}\right)$ but not in muscle specimens held at $4{ }^{\circ} \mathrm{C}$ for 48 hours. Mengeling et al., (1995) exposed 21 pigs to one of three PRRSv strains, with one pig exposed to each virus strain, and pigs were euthanised on days $3,7,14,22,35,49$ and 70 after infection. Specimens were collected from intercostal muscles and muscles from shoulder, ham and loin and examined for virus. PRRSv was isolated from only one pig, from the ham muscle, from a pig slaughtered 7 days after infection. Frey et al., (1995) demonstrated PRRSv (both European and American strains) in pooled samples of ham muscle and bone marrow in pigs slaughtered 6 days post infection. The pooled muscle and bone marrow samples retained infectivity for several weeks when stored at $4{ }^{\circ} \mathrm{C}$ and for one month when stored at $-20{ }^{\circ} \mathrm{C}$. Magar et al., (1995b) also found that PRRSv was isolated in muscle samples collected 7 days after infection from 2 pigs, but not at 14 days after infection. Bloemraad et al., (1994), Mengeling et al., (1995) and Magar et al., (1995b) all suggested that low levels of PRRSv detected in muscle were due to residual infected blood, not because the muscle cells were actively infected with the virus.

To investigate the presence of PRRSv in commercially slaughtered pig meat, Magar et al., (1995b) collected muscle samples from 44 abattoir pigs derived from seropositive herds. No virus was isolated and no viral antigens were detected by immunogold silver staining. The study was expanded to examine by virus isolation 73 lots of frozen packaged pig meat, each composed of 6 pools of meat samples. Meat samples were also tested by reverse transcription - polymerase chain reaction (RT-PCR) (Larochelle and Magar, 1995). All samples were negative by both virus isolation and RT-PCR. For that reason the investigators concluded that pig meat does not retain detectable amounts of PRRSv. Frey et al., (1995) examined 1049 sample pools taken from 178 lots of fresh pig meat (40 $000 \mathrm{lbs}$ per lot) for PRRSv, finding 6 of the sample pools positive for virus. The levels of virus in the positive samples were low; most isolates were only obtained after multiple cell culture passage and re-isolation was not always successful. PRRSv has been recovered only occasionally from commercial pig meat, and levels of virus, when present, are low.

Magar and Larochelle (2004) further examined the presence of PRRSv in pig meat collected at slaughterhouses and its potential transmission to pigs via pig meat. A total of 1039 blood samples were collected from pigs upon arrival at the slaughterhouse and meat samples $(n=1027)$ were collected from the carcasses of these same pigs. Serum samples were tested for antibodies to PRRSv and both serum and meat 
samples were also tested for PRRSv nucleic acid by RT-PCR. Seropositivity to PRRSv for all serum samples was $74.3 \% ; 4.3 \%$ of the total serum samples and $1.9 \%$ of the 1027 meat samples were positive for PRRSv by RT-PCR. Nine of 15 viral RNA-positive samples were field isolates and six of 15 were similar to Ingelvac MLV vaccine. All sequences were determined to be from North American isolates. In only one of the 19 PRRSv-positive meat samples could PRRSv be isolated.

To test the potential infectivity of meat samples containing residual PRRSv, 11 of the PCR-positive meat samples (weighing 1.05 to $1.8 \mathrm{~kg}$ ) were each used in feeding experiments of 2 PRRSv antibody-negative specific pathogen-free pigs of 9 weeks of age. Pigs were starved for 36 hours, and meat, cut into several pieces, was fed to pairs of pigs on 2 consecutive days. Seven pig pairs were found to be infected by PRRSv following ingestion of meat samples, including meat samples containing vaccine-like virus, as judged by the demonstration of PRRSv antibodies and/or PRRSv nucleic acid in the serum within 21 days. Control animals did not seroconvert and were negative for viral RNA by RT-PCR (Magar and Larochelle, 2004). The authors concluded that low residual quantities of PRRSv may be found in a small percentage of pig meat collected at slaughterhouses. Furthermore, when this meat was fed raw to pigs that had been previously deprived of food, pigs could be infected by PRRSv.

Van der Linden et al., (2003a) also examined the transmissibility of PRRSv in meat of infected pigs in an experimental setting. Muscle obtained from pigs infected with either an European strain (EU donor pigs) or American strain (US donor pigs) of PRRSv was fed to PRRSv-free receiver pigs. The donor pigs were slaughtered 11 days after infection. The receiver pigs were deprived of food for two days prior to feeding of raw meat. Five hundred grams of raw semimembranosus muscle from each of the donor pigs was fed over a 2 days period ( $250 \mathrm{~g}$ per day) to each of two receiver pigs (48 receiver pigs). Even under these conditions not all pigs consumed the meat enthusiastically. PRRSv was detected by conventional virus isolation in muscle at 11 days after infection from 7 of 12 EU donor pigs and 5 of 12 US donor pigs. Muscle samples from infected pigs were positive for viral RNA by PCR, except for muscle from one animal infected with the American strain of PRRSv. One of the five groups was fed muscle obtained from US donor pigs that was also spiked with the American strain of PRRSv. Sentinel pigs were placed in contact with the group of receiver pigs fed spiked muscle. All receiver pigs became viraemic by 6 days after feeding. Sentinel pigs in contact with receiver pigs became viraemic. The study demonstrated that PRRSv could be infectious through the oral route via the feeding of meat obtained from recently infected pigs to pigs that had been starved for two days. 
Table 3-5. Virus stability and decay in meat after slaughter

\begin{tabular}{|c|c|c|c|c|}
\hline Reference & $\begin{array}{l}\text { Temperat } \\
\text { ure }\end{array}$ & Half-life & Virus & Notes \\
\hline \multirow[t]{4}{*}{$\begin{array}{l}\text { Benfield et al., } \\
(1992 b)\end{array}$} & 37 & $\begin{array}{l}\text { No virus in } \\
48 \mathrm{hrs}\end{array}$ & \multirow{4}{*}{$\begin{array}{l}\text { North } \\
\text { American } \\
\text { isolate } \\
\text { (VR2332) }\end{array}$} & \multirow{4}{*}{$\begin{array}{l}\text { Virus stable at } 4^{\circ} \mathrm{C} . \\
\text { Media appeared to be } \\
\text { culture media or salt } \\
\text { solution at neutral pH. } \\
\text { Data are virus titres in } \\
\text { tissue culture. }\end{array}$} \\
\hline & 37 & $\begin{array}{l}50 \% \text { decrease in } \\
12 \mathrm{hrs}\end{array}$ & & \\
\hline & 56 & $\begin{array}{l}50 \% \text { decrease in } \\
0.75 \text { hrs }\end{array}$ & & \\
\hline & 4 or lower & $\begin{array}{l}\text { No change in } 4 \\
\text { months }\end{array}$ & & \\
\hline \multirow[t]{4}{*}{$\begin{array}{l}\text { van Alstine et al., } \\
\text { (1993) }\end{array}$} & 25 & $\begin{array}{l}53 \% \text { decrease in } \\
24 \text { hrs }\end{array}$ & \multirow[t]{4}{*}{$\begin{array}{l}\text { North } \\
\text { American } \\
\text { isolate }\end{array}$} & \multirow{4}{*}{$\begin{array}{l}\text { Virus stable at } 4^{\circ} \mathrm{C} \text {. Re- } \\
\text { isolation from tissues } \\
\text { after necropsy. Data are } \\
\text { proportion of successful } \\
\text { re-isolations. }\end{array}$} \\
\hline & 25 & $\begin{array}{l}86 \% \text { decrease in } \\
48 \mathrm{hrs}\end{array}$ & & \\
\hline & 25 & $\begin{array}{l}93 \% \text { decrease in } \\
72 \mathrm{hrs}\end{array}$ & & \\
\hline & 4 and -20 & No change & & \\
\hline \multirow[t]{6}{*}{$\begin{array}{l}\text { Bloemraad et al., } \\
\text { (1994) }\end{array}$} & 56 & $0.1 \mathrm{hrs}$ & \multirow[t]{6}{*}{$\begin{array}{l}\text { European } \\
\text { isolate (LV) }\end{array}$} & \multirow{6}{*}{$\begin{array}{l}\text { Virus titre in muscle at } \\
4^{\circ} \mathrm{C} \text { was slightly } \\
\text { reduced, whereas virus } \\
\text { in serum and lymph } \\
\text { nodes remained stable } \\
\text { over } 48 \mathrm{hrs} \text {. }\end{array}$} \\
\hline & 37 & $3 \mathrm{hrs}$ & & \\
\hline & 21 & $20 \mathrm{hrs}$ & & \\
\hline & 4 & $140 \mathrm{hrs}$ & & \\
\hline & -20 to -70 & Nearly stable & & \\
\hline & $4(\mathrm{pH}$ & $56 \mathrm{hrs}$ & & \\
\hline $\begin{array}{l}\text { Van der Linden et al., } \\
(2003 a)\end{array}$ & & & $\begin{array}{l}\text { EU isolate } \\
\text { (LV) and } \\
\text { North } \\
\text { American } \\
\text { isolate }\end{array}$ & No relevant information \\
\hline $\begin{array}{l}\text { Magar and Larochelle, } \\
(2004)\end{array}$ & & & $\begin{array}{l}\text { North } \\
\text { American } \\
\text { isolates }\end{array}$ & No relevant information \\
\hline
\end{tabular}

\section{Conclusion:}

The time period from slaughter to cutting takes a minimum of 30 hours and the use of fast or intensive cooling results in a quick reduction of the carcass temperature to $7^{\circ} \mathrm{C}$.

PRRS virus is most stable between $p H$ values 5.5 and 6.5 corresponding to the $p H$ observed after carcass maturation. 
PRRSv in pig meat retains its infectivity for months if the meat is frozen. Based on a single study, the D-value (time taken for 1 log reduction of titre) for PRRSv in meat kept at $4^{\circ} \mathrm{C}$ was estimated to be 30 hours.

The proportion of lymphoid tissue in fresh meat has not been quantified. Visible lymph nodes can be removed during the trimming process but this is done not necessarily and not systematically. Lymph nodes in locations not accessible during slaughter (within groups of muscles or viscera) will not be removed.

\subsection{Immunity and Vaccination}

\subsubsection{Replication of vaccine virus}

Three European-genotype live attenuated PRRSv vaccine strains are currently used in Europe (Indik and Valicek, 2002). A live attenuated vaccine of the North Americangenotype is also licensed and used in various European countries. Information on the replication of European -genotype vaccine viruses is scant. The replication of the North American genotype vaccine virus in pigs is characteristic of a live, attenuated virus. It grows in macrophages of the lung and lymphoid tissues at reduced levels compared to virulent PRRSv such that the amount of virus is substantially reduced compared to the amount of virulent virus in a pig under the same conditions (Johnson et al., 2004). The amount of virus in swine is influenced by animal age, with young 6-8 week old pigs showing higher numbers of viraemic and virus-excreting pigs, compared to 6 month old pigs that are near market weight (van der Linden et al., 2003a). These latter workers did not directly analyze vaccine strains, but did perform their experiments using both European- and North American-genotype viruses. Their findings are also applicable to live vaccine strains because vaccine strains have been shown to replicate in the same cells and tissues as do virulent field strains, though to lower levels under the same conditions of inoculation (Johnson et al., 2004). The use of live vaccines may result in vaccinal virus being present at slaughter, as evidenced by the work of Magar and Larochelle, (2004). Because such viruses have shown to spread from pig to pig and after such passages have been associated with disease, they may also represent a hazard to naive pigs (Nielsen et al., 2001).

Previous exposure of pigs to PRRS virus completely prevents or substantially reduces viral load following a subsequent exposure. Vaccination of young pigs with a live vaccine completely prevented growth of a homologous virus following exposure, as determined by absence of viraemia and lack of anamnestic antibody response (Foss et al., 2002). Similarly, vaccination of pigs with a European PRRS vaccine prevented reinfection and viral re-isolation by a homologous wild-type virus strain (Labarque et al., 2004). The duration of homologous immunity is substantial. Pregnant gilts exposed to a field virus late in gestation are protected from re-infection up to 20 months later (Lager et al., 1997; Lager et al., 1999). These observations indicate that exposure of pigs to a PRRS virus completely prevents infection at a later time by the same or related virus.

Most pigs in an endemic herd are infected with PRRS virus within the first 10 weeks of life. In a study of seven continuous flows, farrow-to-finish herds that were endemically infected, Chung et al., (1997) showed that 70 to 100\% of pigs 6 to 9 weeks of age were infected with PRRS virus. Also, virus was not isolated from pigs at 22 weeks of age. Other studies further indicate that most animals are likely to be infected by 10 weeks of age, with rates of $90-100 \%$ at 9-10 weeks of age (Sornsen et al., 1998), 80$100 \%$ at 8-9 weeks of age (Dee et al., 1994), and $40-100 \%$ at 8-10 weeks of age (Dee and Joo, 1997). Taken together, these findings indicate that the majority of pigs in 
PRRSv-infected herds are exposed to virus early in life and will be resistant to reinfection with the virus that is on the farm up to the time of slaughter. An increasingly common practice in endemically infected swine herds is to directly expose pigs to a virulent on-farm isolate in order to protect against re-infection at a later time in life. The practice results in induction of homologous immunity to the resident virus, and it is expected to result in animals that are diagnostically negative for PRRSv at the time of slaughter.

Live vaccines are usually, if not always, genetically distinct from viruses currently circulating in the field. Therefore, vaccination provides heterologous protection to PRRS virus infection. Labarque et al., (2004) showed that a European vaccine reduced the duration of viraemia from about 27 days to about 15 days with the peak level 0.5 to $1 \mathrm{log}$ lower. Viral recovery from lung fluids was also reduced by about $1 \mathrm{log}$ at the peak, and the duration of infection was reduced from 27 days to 15 days, at which time more than $50 \%$ of vaccinated pigs were negative. Studies in adult boars showed that vaccination increases resistance to infection with PRRS virus. In vaccinated boars, virus was isolated by PCR but not by cell culture up to 15 days after challenge, indicating that the levels of virus were low (Molitor et al., 1997b; Magar and Larochelle, 2004). In two trials of five boars, only one animal became infected when challenged with a heterologous field virus. In each case the level of viraemia was lower and the duration was shorter compared to control animals as measured by virus isolation on cell culture (Nielsen et al., 1997; Christopher-Hennings et al., 1997).

\section{Conclusion:}

The use of live vaccines in young and growing pigs will reduce the amount of virus in pigs at the time of challenge and lower the likelihood of viral presence in animals at the time of slaughter. Vaccine viruses present in slaughtered pigs could be a hazard to naive populations.

\subsection{Diagnostics}

Diagnostic methods for detecting PRRS are relevant to this risk assessment, as they are the primary mechanism for determining presence and absence of infection in individual animals.

\subsubsection{Introduction}

Differential diagnosis will include infection with porcine parvovirus, pseudorabies virus, haemagglutinating encephalomyelitis virus, porcine circovirus type 2 , porcine enterovirus, swine influenza virus, classical swine fever (hog cholera) virus and leptospirosis (Keffaber, 1989; Paton et al., 1992b; Mengeling et al., 1993; Halbur et al., 1993; Halbur et al., 1995; Yoon et al., 1996; Allan and Ellis, 2000).

Isolation of PRRS virus from clinical specimens, the detection of viral antigens and/or viral genomic material must be used to confirm the tentative diagnosis in cases when the clinical history and pathology is suggestive of PRRS. Immunohistochemistry staining (IHC), immunofluorescent antibody staining (IFA), reverse-transcriptase polymerase chain reaction (RT-PCR) and virus isolation (VI) can be used to determine the presence of the virus. Also the detection of rising serum antibodies, within an acceptable time frame compatible with the clinical episode, may support the diagnosis (Yoon et al., 2003). However, serology only indicates that a pig has been exposed to 
the virus but cannot tell if the pig remains infected. Correct sample selection, sample handling, and the sensitivity of the test all combine to provide a reliable diagnosis.

\subsubsection{Interpretation of diagnostic sensitivity/specificity}

Diagnostic sensitivity and specificity are as defined in the OIE Manual (2004b) (Ludemann and Magar, 2004). If the sensitivity of a diagnostic test is low, then the true number of positives will be higher than those identified in the testing regime. This will mean that unless a correction is made, the assessed risk will be lower than the true risk. Therefore it is very important in a risk assessment involving diagnoses, to take that into account when assessing the risk.

Conversely, with respect to the specificity, a false positive will overestimate the risk. However, many tests have a high level of specificity. In addition, any animal specifically identified as positive (whether correctly or not) is unlikely to be used for importation. Any problems associated with a low level of specificity are therefore likely to be much less significant in assessing the risk. It should be noted however that false positives may be significant in economic and cost-benefit terms.

\subsubsection{How to collect and transport samples for detection of PRRS}

The isolation and/or detection of PRRSv in clinical materials are highly dependent on proper collection and handling of specimens. For the detection of PRRSv, specimens should be collected as early as possible in the course of the disease, i.e., within the first 7 to 10 days after the onset of illness. Samples collected during the acute phase of viral infection usually contain adequate amounts of virus for detection in available assays. Samples collected later in the course of infection usually require more laboratory time and often yield poor results. Clinical specimens should be collected aseptically, kept fresh $\left(4^{\circ} \mathrm{C}\right)$ and transported immediately to the laboratory. For longer storage periods, freeze samples at $-70^{\circ} \mathrm{C}$, and not at $-20^{\circ} \mathrm{C}$. Ideally, frozen samples should be submitted on dry ice, but commercial refrigerant packs can be used if necessary (Yoon et al., 2003). Repeated freezing and thawing should be avoided.

Serum is the diagnostic specimen of choice in most cases. Paired samples obtained from sows as well as randomly selected samples from nursery and feeder pigs can be submitted to a laboratory for serological evaluation and/or virus isolation. Formalinized tissue samples, e.g. lung and tonsils, can also be used for the detection of PRRSv by histopathology and immunohistochemistry.

\subsubsection{Assays to detect PRRSv}

\subsubsection{Isolation of PRRSv}

PRRSv replicates in porcine alveolar macrophages (PAMs) and certain African monkey kidney cell lines (Wensvoort et al., 1991a; Paton et al., 1992a, b; Yoon et al., 1992b; Dea et al., 1992; Zeman et al., 1993; Bautista et al., 1993). Certain monkey kidney cell lines (e.g. MA-104) can be a good replacement for macrophages (Bautista et al., 1992; Kim et al., 1993) but such cell lines do not support the growth of all isolates, in particular European strains. For the isolation of European-like PRRSv the use of PAMs may be required (Wensvoort et al., 1991a; Dewey et al., 2000).

Virus isolation, carried out in MARC-145 or in PAM cultures, followed by IFA or immunoperoxidase (IP) staining, is the "gold standard" for the detection of PRRSv. 
Additional techniques, such as immunohistochemistry (immunostaining with specific antisera), in situ hybridisation on fixed tissues or cell cultures, and reverse-transcription polymerase chain reaction have been developed for laboratory confirmation of PRRSV infection.

Variability between batches of macrophages in their susceptibility to PRRSv is common. Thus, it is necessary to identify a batch with high susceptibility, and maintain this stock under liquid nitrogen until required (Ludemann and Magar, 2004)

\subsubsection{Sample selection for PRRSv isolation}

PRRSv has been isolated from a variety of clinical specimens, including serum, plasma, peripheral blood mononuclear cells (i.e. buffy coat layer), bone marrow, tonsil, lungs, lymph nodes, thymus, spleen, heart, brain, liver, testis, epididymis, ductus deferens, bulbourethral gland, penile tissue, oropharyngeal scraping, nasal turbinate, nasal swabs, placenta, saliva, urine, faeces, and semen (reviewed by Yoon et al., 2003). Fluid samples collected from the lungs (bronchioalveolar fluid) and serum are considered as the preferred specimens for virus isolation during the acute phase of a PRRS outbreak. PRRSv is more stable in serum than in tissue (Van Alstine et al., 1993; Mengeling et al., 1995; Rossow, 1998). In older animals, viraemia is of short duration and PRRSv may be found in tissues longer than in serum (Christopher-Hennings et al., 2001). If tissues are submitted, they should include lung, tonsil, and lymph nodes (Joo, 1993). In acute infected animals, serum, lung, and bronchioalveolar lavage fluid are samples of choice for the isolation of PRRSv, while for virus isolation from persistently infected animals, tonsil, oropharyngeal scraping, and bronchioalveolar lavage fluid are better samples than serum and lung. In cases of late-term abortion and early farrowing, samples should be collected from weak-born, pre-suckle pigs, rather than mummies, aborted, or stillborn pigs. Within affected litters, weak-born pigs are the most likely to be viraemic, but the presence of high levels of maternal antibody to PRRSv may hinder attempts at virus isolation (Yoon et al., 2003).

\subsubsection{Bioassay for the detection of infectious PRRSv}

The bioassay is one of the most sensitive methods for the detection of infectious PRRSv, as large volumes of sample can be used compared to virus isolation. For the detection of PRRSv, volumes up to $10 \mathrm{ml}$ were injected intra-peritoneally in 10 week old naive pigs (van Rijn et al., 2004). This relatively expensive method of PRRSv detection can be used for samples that are toxic for cell cultures, e.g. boar semen.

3.6.4.4. Detection of PRRSv antigens by fluorescent antibody test and immunohistochemistry

For detecting PRRSv antigen in tissues, the IFA on frozen tissue sections and IHC test may be used. The direct IFA test on frozen tissue sections is inexpensive, rapid and specific, but the sensitivity is rather low (chance of false negative results). Comparison of virus isolation, immunohistochemistry and fetal serology for the identification of PRRSv transplacental infection in the fetus showed that most infections were detected by virus isolation (Benson et al., 2002). Another comparative study for the detection of PRRSv from naturally aborted fetuses and stillborn piglets showed that RT-PCR identified the presence of PRRSv more frequently than virus isolation, immunohistochemistry and in situ-hybridisation (Cheon and Chae, 2000). 
Sample quality greatly affects IFA test results. Tissue should be collected from recently dead or euthanized pigs and promptly refrigerated or frozen. In contrast, IHC is useful for detecting virus in formalin-fixed tissues. IHC is more sensitive than the direct IFA examination of frozen tissues, but IHC is laborious and it is more expensive than the FA test. A definitive diagnosis can be accomplished by detection of microscopic lesions characteristic of PRRSv in conjunction with IHC or IFA tests. For direct IFA examination, fresh or frozen tissues should be submitted. For IHC examination, tissues should be fixed in 10 percent neutral buffered formalin. Preferred tissues for these tests are heart, kidney, lung, lymph nodes, spleen, thymus, and tonsil. PRRS viral antigens may also be detected in the adrenal gland, intestine, liver, and occasionally in the brain (Halbur et al., 1994b; Halbur et al., 1995; Rossow et al., 1999; Yoon et al., 2003). When performing antigen detection tests, such as IFA and IHC, laboratories have to make a decision whether to test for the US-type, the European-type PRRSv or both.

\subsubsection{Tests based on the genetics of PRRSv}

PRRSv is genetically heterogeneous with extensive sequence variation occurring between and within European and US isolates (Meng, 2000). Recently, in Poland and Lithuania PRRSv variants were detected with sequences that were exceptionally different from the European prototype, the Lelystad virus (Stadejek et al., 2002). A number of mechanisms have been proposed to explain the genetic heterogeneity of PRRSv and persistence of infection and it is likely that, as an RNA virus, the phenomenon of quasi-species variation will play a part in such (Rowland et al., 1999). Methods, based on the genetic-based testing for PRRSv, should take account of the differences in sequences occurring between PRRSv strains and the divergent evolution exhibited by this virus.

Reverse transcriptase-polymerase chain reaction based tests have been developed for detecting PRRSv RNA in clinical specimens. RT-PCR based methods on the detection of viral PRRSv RNA can detect either infectious or non-infectious virus, and it is not the same as the isolation of virus. Some advantages of RT-PCR methods, above virus isolation techniques, are: a) since the virus does not need to be isolated in cell culture to detect the viral RNA, RT-PCR can be performed in a shorter amount of time than virus isolation, and $b$ ) the presence of (neutralising) antibodies does not interfere with test results. In addition, RT-PCR can also be used for the detection of PRRSv in samples like semen, fetal tissues, thoracic fluids or faeces because these samples are difficult to analyze by traditional methods (Benson et al., 2002; Yoon et al., 2003). However, it should be recognised that both false negative as positive RT-PCR results may occur (Wagstrom et al., 2000).

Several types of RT-PCR-based assays have been developed, most being designed to detect regions of the virus called ORF7, ORF6 or ORF1b and can be run directly on diagnostic specimens (reviewed by Yoon et al., 2003). Some RT-PCR assays are based on a "nested" principle (RT-nPCR) for added sensitivity. More recently, automated fluorogenic RT-PCR-based tests, such as the TaqMan ${ }^{\mathrm{TM}}$ PCR (Molitor et al., 1997b; Wagstrom et al., 2000; Bierk et al., 2000; Egli et al., 2001; Balasuriya et al., 2002), Light-Cycler"T PCR (van Rijn et al., 2004) or "Molecular Beacon" PCR (Carlson et al., 2002) have been developed to improve the quality of conventional RT-PCR tests for detecting PRRSv in clinical specimens.

The use of RT-PCR assays has become more common both for the diagnosis of PRRS and to aid in herd monitoring and control i.e. screening of replacement animals, detection of persistently infected animals, and test and removal programs (Donadeu et 
al., 1999; Bierk et al., 2001; Horter et al., 2002; Kleiboeker et al., 2002; van Rijn et al., 2004).

As a general principle, RT-PCR-based assays are believed to be highly sensitive and highly specific (Horter et al., 2002; Benson et al., 2002). The RT-PCR was slightly more sensitive than virus isolation for the detection of virus in serum and markedly more sensitive than virus isolation for the detection of virus from plasma. In this study the RT-PCR was able to detect 1 TCID $_{50}$ of PRRSv (Spagnuolo-Weaver et al., 1998). These data indicate that RT-PCR tests are more sensitive than virus isolation; however, the performance of PCR testing among different laboratories may vary depending upon sample condition, sample processing, laboratory technique, and the skills and experience of the technician performing the assay. Therefore, it is important to validate RT-PCR tests. In addition, also the matrix is of importance as heparin-treated plasma should be avoided for RT-PCR, since this is a known inhibitor of the PCR (Taylor, 1997; Spagnuolo-Weaver et al., 1998). Validation results on the reliability of developed PCR tests should be provided to producers and veterinarians.

\subsubsection{Methods for the detection of PRRSv in meat}

Several RT-PCR tests have been used for the detection of PRRSv in meat. Primers and probes selected in conserved regions at the junctions of ORF6 and ORF7 of PRRSv were used (van der Linden et al., 2003a; Magar and Larochelle, 2004). In the study of van der Linden et al., (2003a), the limit of detection of the virus isolation assay was $10^{1.8} \mathrm{TCID}_{50} /$ gram, while the reported detection limit of the RT-PCR was $10^{0.08} \mathrm{TCID}_{50}$. However, the reported detection limit of the RT-PCR was based on the detection of PRRSv in semen. Currently, no data are presented on the detection limits of RT-PCR methods for meat. Recent data (Xiao et al., 2004) have revealed sternal lymph node as being a sensitive sample for detection of virus, so may be suitable for monitoring whole carcases.

\subsubsection{Assays to detect of serum antibodies against PRRSv (serology)}

Several kinds of serologic tests are available including the indirect immunofluorescent antibody (indirect-IFA), the immunoperoxidase monolayer assay (IPMA), enzyme-linked immunosorbent assay (ELISA) and serum virus neutralization (SVN). These tests have all been used for the detection of antibodies specific for PRRSv, but ELISAs are being used in most diagnostic laboratories, especially to examine the PRRSv antibody status on herd level. Serological tests are often performed with viral antigens of only one antigenic type, which means that antibodies directed against the other, heterologous, antigenic type may be detected with less sensitivity. Both the immunoperoxidase monolayer assay and the indirect immunofluorescence assay can however be designed with both PRRSv types. One commercial ELISA is specific for detecting antibodies directed against both the European-type and American-type PRRSv.

\subsubsection{Indirect immunofluorescent assay (indirect-IFA)}

Although there is no single standard accepted indirect immunofluorescent assay (indirect-IFA) in use at this time, several indirect-IFA protocols have been developed and are used by different laboratories, mainly in North America. The indirect-IFA is thought to have high specificity $(99.5 \%)$ but unknown sensitivity for individual animals (Yoon et al., 1992a). An advantage of the indirect-IFA test compared to ELISA is that the magnitude of the antibody titre can be determined. Indirect-IFA antibody titres of 16 or 20, depending upon the initial serum dilution for the test, are considered positive. However, test results or endpoint antibody titres may vary depending on the 
degree to which the PRRSv strain used in the assay differs from the isolate that infected the pig (Bautista et al., 1993). The indirect-IFA reliably detects specific antibodies for 2 to 3 months after infection (Frey et al., 1992; Yoon et al., 1995c).

\subsubsection{IPMA}

IPMA usually detects antibodies to PRRSv between 7 and 15 days after infection (Wensvoort et al., 1991a; Ohlinger et al., 1992), and IPMA also reliably detects specific PRRSv antibodies for 2 to 3 months after infection (Ohlinger et al., 1992; Frey M et al., 1992; Yoon et al., 1995c). As with indirect-IFA, the relatedness of the virus strain used in the assay and the virus strain infecting the pig will likely affect the performance of the IPMA test (Wensvoort, 1992; Yoon et al., 2003).

The IPMA, reported to be the "gold standard", is also considered to be a highly specific and sensitive test (Wensvoort et al., 1991b). In one comparative study, the sensitivity of IPMA was better than that of a commercial ELISA (Drew, 1995).

\subsubsection{SVN}

The SVN test is a very specific test, but it is less sensitive than indirect-IFA, IPMA and ELISA (Morrison et al., 1992b; Benfield et al., 1994). The low sensitivity of the test is primarily due to the fact that neutralizing antibody titres against PRRSv of $\geq 4$, which is the titre to be considered as positive, develop as late as 1 to 2 months after infection (reviewed by Yoon et al., 2003). As with indirect-IFA and IPMA, SVN test results are greatly influenced by the degree of relatedness between the isolate employed in the test and the isolate infecting pigs (Wensvoort et al., 1992; Yoon et al., 1997). In addition, antigenic differences between the virus isolate used in the test and the PRRSv type in the herd can cause decreased sensitivity (Rossow, 1998; Madsen et al., 1998). Therefore, the SVN results do not correlate well with the ELISA results. The SVN test is very laborious and the SVN is considered to be more or less a research tool rather than a routine diagnostic test.

\subsubsection{ELISA}

Many reports showed that the ELISA was a sensitive and specific test for the detection of PRRSv antibodies (Albina et al., 1992; Drew, 1995; Yoon et al., 1995c; Snyder et al., 1995; Houben et al., 1995a; Nodelijk et al., 1996; Takikawa et al., 1996; O'Connor et al., 2002). Serological diagnosis by ELISA is in general easy to perform with good specificity and sensitivity, especially on a herd basis. Sera of individual pigs sometimes cause difficulties in certain ELISAs because of non-specific reactions, but this problem may be solved by re-sampling the pig after 2-3 weeks.

Several ELISA formats have been described (Yoon et al., 2003): an indirect ELISA using a sample to positive (S/P) ratio system, an indirect ELISA using direct OD values, an indirect ELISA using recombinant nucleocapsid protein as antigen (Denac et al., 1997), and a blocking ELISA (Ferrin et al., 2002; Houben et al., 1995a; Sorensen et al., 1997; Ferrin et al., 2004; Zhou et al., (2001). Evaluation of the blocking ELISA for the screening of PRRSv antibodies showed that the blocking ELISA was comparable to the IPMA and better results were obtained compared to the indirect ELISA in detecting antibodies formed early after infection (Sorensen et al., 1997). A recently developed blocking ELISA, based on the use of an expressed PRRSv nucleocapsid ( $N$ ) protein as antigen, showed a diagnostic sensitivity of $97.8 \%$ and diagnostic specificity of $100 \%$. However, no ELISA data on sera from European type PRRSv were reported for this blocking ELISA (Ferrin et al., 2004). 
In one commercial ELISA kit, developed as a herd-screening tool and not suitable for individual animal certification (Botner, 1997), an S/P ratio $\geq 0.4$ is considered positive. Using the S/P ratio of 0.4 as a cut off, PRRSv-specific antibody is detected in young pigs between 10 to 14 days post inoculation under experimental conditions and peaks at 2 to 3 months (Yoon et al., 1993; Yoon et al., 1995c). It has been reported that the PRRSv indirect ELISA had a sensitivity of 96.1 to near 100\% (Drew, 1995; Snyder, 1995, Cho et al., 1997). The specificity of this commercial PRRS ELISA has been estimated to be between 99.3 and 99.5\% (O'Connor et al., 2002; Nodelijk et al., 1996; Yoon et al., 2003).

Recently a newer version of this test has been made available to veterinary diagnostic laboratories and practitioners. According to the manufacturer, this test has a sensitivity of $97.4 \%$ and a specificity value of $99.6 \%$. One of the advantages of the commercial ELISA is that it includes the detection of antibodies directed against both American and European type PRRSv strains.

In most cases, antibodies directed against PRRSv often do not persist for the lifetime of an animal. Under experimental conditions, PRRSv-specific IgM antibodies can be detected within 5 days post inoculation and IgM antibodies can be detected approximately 21 to 28 days post inoculation (Park et al., 1995). PRRSv-specific antibodies can be detected by the IgG-indirect-IFA, IPMA, ELISA, and the SVN test at 5 to 9,9 to 11, 9 to 13, and 9 to 28 days post inoculation, respectively. Depending on the assay, antibody levels reach their peak values by 30 to 50 (indirect-IFA), 35 to 50 (IPMA), 30 to 50 (ELISA), and 60 to 90 days post inoculation (SVN), after which they begin to decline (Yoon et al., 2003). It has been estimated from experimental and field observations that antibody titres approach undetectable levels by 4 to 5 months (indirect-IFA), 4 to $\geq 10$ months (ELISA), 11 to 12 months (IPMA), and 12 months (SVN) post infection (Yoon et al., 1995b, c). The same time frame would be expected in those pigs that have been vaccinated with MLV vaccine.

The detection of PRRSv antibodies in a single blood sample collected from an individual pig is generally insufficient for confirming a diagnosis of PRRS or for confirming the presence of PRRSv (van Alstine et al., 1993; Henry, 1994). Additional tests are required to confirm the PRRSv diagnosis or the presence of PRRSv in e.g. slaughter pigs (Christianson and Joo, 1994; Goyal, 1993). In addition, current serologic assays cannot routinely differentiate between antibodies derived from vaccine-viruses and field isolates.

On the other hand, serum samples can be tested negative for PRRSv antibodies in cases that pigs are recently infected with the virus but have not yet had time to seroconvert. In addition, the result can also be falsely negative due to poor sensitivity of the test or a laboratory error (AASP, 1996). Therefore, serologic tests are better suited for determining the PRRSv status of a population (within herds) and not for the PRRSv status of individual animals. False-positive reactions in de commercial antibody ELISA might occur (Torremorell et al., 2002). These sera should be retested for the presence of PRRSv antibodies. A few in-house ELISAs have been developed for more specific detection of PRRSv antibody positive animals (Ferrin et al., 2002; Ferrin et al., 2004; Zhou et al., 2001).

\subsubsection{Differentiation between European and American type PRRSv antibodies}

A blocking ELISA has been used extensively in Denmark (Sorensen et al., 1997) and has been described as a double ELISA set-up using both European and American virus 
as antigen and thus it can distinguish between serological reaction to the European and the American types (Sorensen et al., 1998). Reaction to American-type vaccinelike PRRSv can be anticipated in countries using or having used the live attenuated vaccine for PRRSv based on the American type virus as vaccine; European countries may therefore observe reactions and isolation of both antigenic types (Botner, 1997; Madsen et al., 1998; Wellenberg et al., 2004). The identification of European-type strains of PRRSv in the USA and Canada has been reported recently, but the prevalence of infection by such strains is not well documented at this time (Ludemann and Magar, 2004). A tandem PRRS ELISA, based on purified recombinant nucleocapsid protein, was developed for the detection and differentiation of antibodies against European and North-American PRRSv. The sensitivity and specificity values of this ELISA were $\geq 0.93$ for antibodies directed against both European-type and American-type PRRSv (Seuberlich et al., 2002).

\subsubsection{Differentiation between PRRSv isolates}

Although above mentioned serological assays can discriminate between European and American type PRRSv antibodies, serologic assays cannot routinely differentiate between antibodies derived from field isolates or from vaccine-viruses. Several methods have been developed to characterize PRRSv isolates, to differentiate European isolates from North American isolates or to differentiate commercial modified-live vaccine virus from field isolates. These include methods based on panels of monoclonal antibodies, PCR with or without a restriction fragment length polymorphism (RFLP) assay, a hetero-duplex mobility assay (HMA), and direct DNA sequencing (reviewed by Yoon et al., 2003). 


\subsubsection{Summary of diagnostic tests}

Table 3.6. below summarises the information required by this risk assessment on diagnostic tests.

Table 3-6. Summary on diagnostic tests for PPRS

\begin{tabular}{|c|c|c|c|c|c|}
\hline Test & $\begin{array}{l}\text { Diagnostic } \\
\text { detection } \\
\text { limits }\end{array}$ & $\begin{array}{l}\text { Sensitivity } \\
\text { (range) }\end{array}$ & $\begin{array}{l}\text { Specificity } \\
\text { (range) }\end{array}$ & References & Comments \\
\hline $\begin{array}{l}\text { Indirect -IFA } \\
\text { (antibody } \\
\text { test) }\end{array}$ & 5-9 dpi & $100 \%$ & $95-100 \%$ & $\begin{array}{l}\text { Fichtner et al., } \\
\text { 1994, Takashima } \\
\text { et al., 1999, Yoon } \\
\text { et al., 1992a, } \\
\text { Yoon et al., } 2003\end{array}$ & $\begin{array}{l}\text { Validation results are } \\
\text { greatly influenced by } \\
\text { the degree of } \\
\text { relatedness between } \\
\text { the isolate employed } \\
\text { in the test and the } \\
\text { isolate infecting pigs }\end{array}$ \\
\hline IPMA & $7-15$ dpi & $95-100 \%$ & $87-97 \%$ & $\begin{array}{l}\text { Fichtner et al., } \\
\text { 1994, Nodelijk et } \\
\text { al., 1996, } \\
\text { Takashima et al., } \\
\text { 1999, Reviewed } \\
\text { by Yoon et al., } \\
(2003)\end{array}$ & $\begin{array}{l}\text { Validation results are } \\
\text { greatly influenced by } \\
\text { the degree of } \\
\text { relatedness between } \\
\text { the isolate employed } \\
\text { in the test and the } \\
\text { isolate infecting pigs }\end{array}$ \\
\hline SVN & $8-28 d p i$ & na & $\mathrm{Na}$ & $\begin{array}{l}\text { Takikawa et al., } \\
\text { 1996, Reviewed } \\
\text { by Yoon et al., } \\
(2003)\end{array}$ & $\begin{array}{l}\text { Low sensitivity. } \\
\text { Validation results are } \\
\text { greatly influenced by } \\
\text { the degree of } \\
\text { relatedness between } \\
\text { the isolate employed } \\
\text { in the test and the } \\
\text { isolate infecting pigs. }\end{array}$ \\
\hline ELISA & 9-14 dpi & $\begin{array}{l}96.1-\text { near } \\
100 \%\end{array}$ & $\begin{array}{l}99.3- \\
99.5 \%\end{array}$ & $\begin{array}{l}\text { Drew (1995), } \\
\text { Snyder (1995), } \\
\text { Cho et al., (1997), } \\
\text { O'Conner et al., } \\
\text { (2002), Nodelijk } \\
\text { et al. (1996), } \\
\text { Yoon et al., 2003) }\end{array}$ & $\begin{array}{l}\text { The specificity of the } \\
\text { indirect-ELISA was } \\
\text { also examined on } \\
\text { meat juice samples } \\
\text { (98\%; Mortensen et } \\
\text { al., 2001) }\end{array}$ \\
\hline $\begin{array}{l}\text { ELISA } \\
\text { (modified } \\
\text { ELISA) }\end{array}$ & na & $97.4 \%$ & $99.6 \%$ & $\begin{array}{l}\text { Idexx } \\
\text { laboratories, } \\
\text { Maine, USA }\end{array}$ & \\
\hline $\begin{array}{l}\text { ELISA (in } \\
\text { house test) }\end{array}$ & na & $97.8 \%$ & $100 \%$ & $\begin{array}{l}\text { Ferrin et al., } \\
(2004)\end{array}$ & $\begin{array}{l}\text { (data presented as } \\
\text { diagnostic sensitivity } \\
\text { and-specificity) }\end{array}$ \\
\hline
\end{tabular}

Abbreviations: Indirect-IFA: indirect-immunofluorescent antibody assay (indirect-IFA), IPMA: immunoperoxidase monolayer assay, ELISA: enzyme-linked immunosorbent assay, SVN: serum virus neutralization, dpi: days post infection, na: No available data,

Several RT-PCR based tests have been developed for detecting PRRSv RNA in various clinical specimens, such as semen, lymph nodes, foetal tissues, thoracic fluids, faeces but also in meat. As a general principle, RT-PCR based assays are believed to be as sensitive as virus isolation and in some studies the RT-PCR showed to be even slightly more sensitive than virus isolation (sensitivity range for serum, semen or lung tissue samples: 0.08 - 10 TCID $_{50}$; (Mardassi et al., 1994; Spagnuolo-Weaver et al., 1998; Egli et al., 2001; van Rijn et al., 2004; Chung et al., 2005; Kleiboeker et al., 2005). 
Although PCR tests have been applied for detection of PRRSv in meat (Frey et al., 1995; Larochelle and Magar, 1997; van der Linden et al., 2003a; Magar and Larochelle, 2004), their sensitivity is unknown, since they have not been specifically configured or validated for this application.

\section{Conclusions:}

Diagnostic tests described above are reliable for determination of the status of the herd. Tests which detect the viral genome are very sensitive but a positive result may not indicate the presence of infectious virus. Virus isolation is a reliable in vitro test for detection of viable virus in meat but an in vivo bioassay is the most sensitive

RT-PCR tests are considered very sensitive; however the performance of RT-PCR testing among different laboratories may vary depending upon sample condition, sample matrices, sample processing, laboratory technique, and the skills and experience of the technician performing the assay.

\section{Conclusions on hazard identification:}

PPRS is a virus disease of pigs that is associated with loss of production and is widespread in most countries with intensive pig production. The most common ways of long distance transmission are via movement of infected live animals and semen. It has been speculated whether PRRSv can be transmitted via meat. Results of laboratory experiments indicate that this is possible. The question is how likely this is under natural conditions. Studies of presence of PRRS virus in slaughterhouses indicate a low prevalence of PRRSv in meat. However, before this meat can constitute a real risk, any virus has to survive maturation, storage and transport. Finally, viable virus must be ingested by a susceptible pig and be present in sufficient amount to result in infection. In considering the available evidence, we conclude that infectious PRRS virus in fresh pig meat may constitute a hazard when exported from a country or region with PRRS to a country with a naive pig population. 


\section{Risk Pathways}

Risk pathways describe the series of events required in order that the hazard under consideration results in the unwanted outcome. According to the mandate (section 2.2.) this risk assessment should assess the risk of transmitting PRRS via fresh meat to naive pig populations, which may be exposed to the virus via (illegal) feeding of catering waste (swill). The risk assessment considers only infectious virus and the following series of events are necessary for this to happen:

Release assessment:

1. PRRS virus must be present in the country of interest.

2. PRRS virus must be present in the herd.

3. PRRS virus must be present in pigs at slaughter.

4. PRRS virus must be present in pig meat after the entire slaughter process.

5. PRRS virus must survive maturing and subsequent storing including transport. Virus could also survive in inedible parts, i.e. refuse and waste, packing material and effluents.

\section{Exposure assessment:}

6. Pig meat or inedible parts containing PRRS virus must be fed to a naive pig population.

7. Finally, these pigs must receive an exposure dose sufficient to cause infection via the feeding of pig meat or inedible parts containing PRRS virus.

A risk assessment contains, among others, a release assessment and exposure assessment. The release assessment in this case deals with the likelihoods associated with steps 1 to 5 (Fig. 5-1.). The exposure assessment deals with the likelihoods associated with steps 6 and 7. Both release and exposure must occur before PRRS in pig meat can be identified as a hazard for the importing PRRS-free country.

We interpret naive pig populations (as stated in the mandate in section 2.2. as the entire national pig herd in a country free of PRRS. The role of meat in introducing infection into a subpopulation that is free of PRRS in a PRRS-infected country is not specifically considered, since the main ways of transmission are movement of infected animals or semen and local spread in particular due to aerosols as noted in section 3.3.4. The risk is assumed to be similar as for a country free of PRRS. 
5. Risk Assessment for Risk Question 1: What is the probability of viable PRRS virus in meat?

\subsection{Description of pathway and associated probabilities leading to residual PRRS virus in pig meat}

Figure 5-1 describes the post-slaughter scenarios and the biological pathway that would result in residual PRRS virus existing in pig meat after slaughter, transport, and storage leading to its release in a PRRS-free country importing pig meat from a PRRSpositive country (adapted from Murray, 2001). The process can be broken down to 4 steps, as described in the following sections.

Figure 5-1. Biological pathways necessary for release of PRRS virus

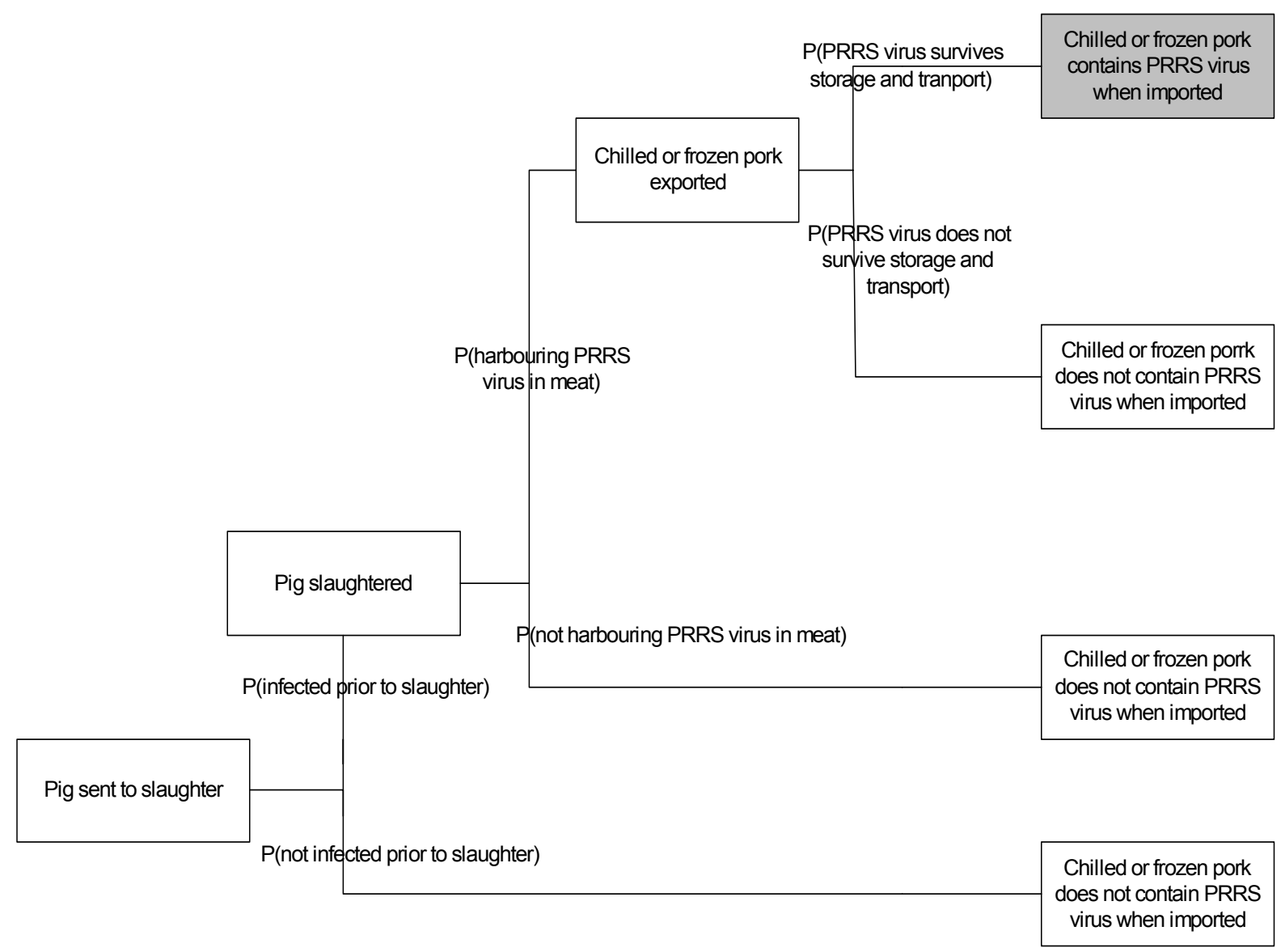

Step 1: Pig infected with PRRS prior to slaughter

\section{Step 1a: Herd prevalence}

In countries with intensive pig production, the between-herd prevalence of PRRS virus infection, based on seroprevalence studies, varies between 60 and $80 \%$ (section 3.3.2.1). The probability that a herd has been or is infected was set to $80 \%$ in the modelling. 


\section{Step 1b: Within-herd prevalence}

According to Mortensen et al., (2001) 83\% of finishers in 1,603 infected herds were seropositive (section 3.3.3). Therefore, a within-herd prevalence of $83 \%$ was used in the modelling.

The resulting probability that a random pig sent to slaughter has been or still is infected prior to slaughter is:

$$
\begin{aligned}
& P(\text { infected prior })=P(\text { herd infected }) \times P(\text { pig infected given herd infected }) \\
& =0.80 \times 0.83=0.66
\end{aligned}
$$

Step 2: Pig harbouring PRRS virus in meat at slaughter PRRS virus usually infects weaners at an age of 5 to 12 weeks, occasionally up to 16 weeks, or even up to the age of slaughter (section 3.3.3). Prevalence of viraemia by age of pig has been described by Chung et al., (1997). In that study, performed in 7 sow herds, all pigs stopped shedding virus at an age of 22 weeks (154 days), which is around 2 weeks before average time of slaughter of bacon pigs. In a study by Mateusen et al., (2002) of 20 Belgian farrow-to-finish pig herds, the PRRSv seroprevalence was shown to increase gradually until the time of slaughter when measured in pigs of 4 weeks, 10 weeks, 16 weeks and 24 weeks of age, respectively Taken together, these data indicate that, although PRRS virus is highly transmissible, in some farms the spread of infection may be delayed and some animals may escape infection until later in life. For example Dewey et al., (2004) found that in 1 out of 8 farms, only around $12 \%$ of the nursery pigs were infected by the age of 11 weeks - an age where most pigs were already infected in the other 7 farms. Mortensen et al., (2001) found that only $83 \%$ of all finishers in 1,603 infected pig herds were infected by the time of slaughter. Therefore, it was decided to model the prevalence of viraemia at the time of slaughter. This is dependent on a number of variables, which include:

1) The age at which the pig becomes infected,

2) The duration of viraemia,

3) The age the pig is slaughtered.

It is less likely that the presence of PRRS virus in meat reflects persistent viraemia. This is partly because persistent viraemia is not well documented but also because a pig that is persistently viraemic is most likely not growing and gaining weight normally. Therefore, such animals will reach slaughter weight at an older age. Moreover, if a pig were slaughtered at a very early age, it would have had a daily weight gain above $900 \mathrm{~g}$, which is highly unlikely for a sick pig (an increase of weight from $8 \mathrm{~kg}$ to $100 \mathrm{~kg}$ from weaning e.g. at day 28 to slaughter at day 128 would imply a daily weight gain of 920g).

\section{Step 2a: Age the pig becomes infected}

Based on the data of Mateusen et al., (2002) a probability distribution was set up to describe the cumulative distribution of seroprevalence, according to age. The increase in the proportion of animals that seroconverted between two points in time reflected the proportion of new cases (incidence). A gamma distribution was used to describe the incidence curve, with parameters based on that which resulted in a distribution that best reflected the proportion of newly infected pigs before 10 weeks, between 10 and 16 weeks, between 16 and 24 weeks, and allowing for the remaining part to 
become infected later (chosen distribution: Gamma with parameters $a=2.4, b=19$, shift=30). A measurement of seroprevalence is a measurement of antibodies, and these develop at least 7 days after infection (Nielsen et al., 1997; Duan et al., 1997b). This implies that the probability distribution describing the onset of viraemia - that occurs soon after infection - can be described by shifting the seroprevalence distribution 7 days to the left (chosen distribution: Gamma with parameters $a=\mathbf{2 . 4}$, $b=19$, shift= 23).

\section{Step 2b: Duration of viraemia}

Pigs are usually viraemic for up to 3 weeks (Nielsen et al., 1997; Duan et al., 1997b). A pert distribution was used in the modelling with a minimum of 2 weeks, a mode of 18 days, and a maximum of 3 weeks. It was also assumed that the duration of viraemia is independent on the age the pigs become infected.

The distribution describing the age the pig becomes infected was combined with the distribution describing the duration of viraemia. The resulting distribution was interpreted as the last day the pigs are viraemic (curve to the left, $90 \%$ confidence interval indicated) and slaughter age (curve to the right) as shown in Figure 5-2 below.

Figure 5-2 Distribution of last day of viraemia and slaughter age

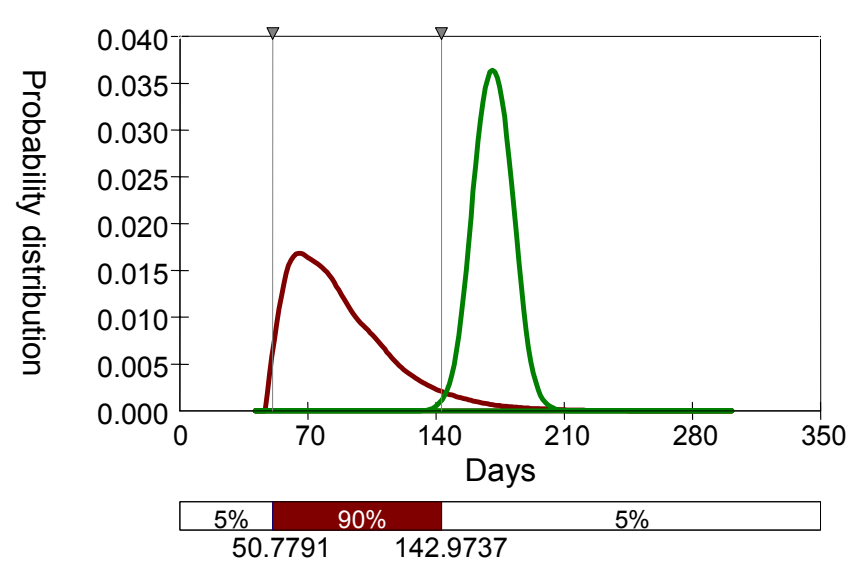

\section{Step 2c: Age at slaughter}

Pigs are slaughtered at different weights (and thereby, ages), depending on the intended use of the pig meat. Pigs intended for bacon production are slaughtered at an earlier age, whereas pigs intended for production of Parma ham or Jamon Iberico are slaughtered at a later age. The prevalence of viraemia among finisher pigs decreases with age. Therefore, bacon pigs can be expected to present the worst-case scenario with respect to prevalence of viraemia.

Detailed data on slaughter age of bacon pigs exist for Denmark. The average age at slaughter is 171 days ( $s d=10$ days) corresponding to 24.4 weeks ( $s d=1.4$ weeks). This implies that $90 \%$ of the pigs are slaughtered between 155 to 187 days of age (assuming a normal distribution) (Fig. 5-2). These data originate from the Danish efficacy recording system, April 2004. The standard deviation (sd) was derived from expert opinion based on data on observed standard deviation on birth weight and 
finisher weight (Danish Bacon \& Meat Council). Compared to US data on slaughter age, the mean and the lower end of the distribution are similar (Murray, 2001). However, a larger proportion of US finishers are slaughtered at a higher age than in Denmark.

\section{Step 2d: Pig harbouring PRRS virus at slaughter (viraemia)}

It is noted that the distribution describing last day in viraemia overlaps slightly with the slaughter age distribution (Fig. 5-2). The probability that a pig infected prior to slaughter contains PRRS virus can be obtained by first sampling a pig from the slaughter age distribution, and then determining the likelihood that a pig of the given age is viraemic by sampling from the viraemia/age distribution. This was done 10,000 times using the software programme @Risk. The resulting mean probability that an infected pig is contaminated with PRRS virus was estimated to be 0.029 .

$\mathrm{P}($ viraemia given infected prior $)=0.029$

The combined probability that a pig randomly chosen at slaughter would harbour PRRS virus was then:

$\mathrm{P}(\mathrm{PRRS}$ virus positive $)=\mathrm{P}($ infected prior $) \times \mathrm{P}$ (harbouring $\mathrm{PRRS}$ virus given infected prior)

$=0.66 \times 0.029=0.019=1.9 \%(90 \%$ C.I. $0.9-3.4 \%)$

Step 3: Survival of PRRS virus in pig meat during maturation, de-boning, transport and storage

The presence of PRRSv in meat is assumed to reflect mainly viraemia (free or cellbound) since viral replication has not been demonstrated in either muscle or endothelial cells (section 3.4.2). Depending on the particular cuts, interspersed lymphoid tissue may also contribute to viral load.

\section{Step 3a: Virus titres in muscles of pigs that are viraemic at slaughter}

Peak titres of around $10^{4} \mathrm{TCID}_{50} / \mathrm{ml}$ in blood occur 7-14 days post infection (Duan et al., 1997b). Thereafter the titre declines (section 3.4.3). Normally, a residual amount of blood $(0,2-0,9 \% \mathrm{v} / \mathrm{w})$ can be found in the carcass muscles. In the case of insufficient bleeding this amount may be higher (Warris, 1984). From these figures it can be estimated that the initial virus titre in muscle will be approximately $1 \%$ of the corresponding figure of blood.

Experimentally, titres in meat up to $10^{3.3}$ to $10^{4.3} \mathrm{TCID}_{50} / \mathrm{g}$ have been observed. This was found in $60 \%$ of experimentally infected pig whereas virus titres in the remaining $40 \%$ of viraemic animals were below the detection limit $\left(10^{1.8} \mathrm{TCID}_{50} / \mathrm{g}\right)$ (Steverinck, 1999). Likewise, Bloemraad et al., (1994) found virus titres of $10^{2.8}-10^{3.7} \mathrm{TCID}_{50} / \mathrm{g}$ in meat at 0 and 24 hours after slaughter in pigs euthanized 5 or 10 days post inoculation (section 3.4.4).

\section{Conclusion:}


Virus titres in muscle can be expected to be 100 times lower than those found in blood immediately after slaughter and bleeding. However, insufficient bleeding will significantly increase the amount of virus retained in muscle.

\section{Step 3b: Effect of maturation}

The time period from slaughter to cutting takes a minimum of 30 hours - longer when slaughtering takes place on a Friday and cutting on the following Monday. The initial carcass temperature after slaughter is 39 to $42^{\circ} \mathrm{C}$, not $37^{\circ} \mathrm{C}$, because of anaerobic glycolysis and technological processes (Beutling, 1992). Various cooling systems are applied commercially, with the result that the time needed to reach desired core temperature of the carcass of $7^{\circ} \mathrm{C}$ ranges from 12 hours with fast cooling systems to 1.5 hours with shock cooling/intensive cooling systems (Ortner, 1988; Beutling, 1992). For example, some Danish pig abattoirs have applied a system where the temperature of the ham and shoulder reaches $15^{\circ} \mathrm{C}$ within 6 hours, whereas other Danish abattoirs employ an even more rapid cooling process. Other cooling systems in use in Europe result in temperatures below $30^{\circ} \mathrm{C}$ after 6 hours and below $10^{\circ} \mathrm{C}$ after approx. $19-20$ hours.

Several authors have studied the association between temperature, time, $\mathrm{pH}$, and virus inactivation (section 3.4.4). PRRS virus is most stable between $\mathrm{pH}$ values 5.5 and 6.5. (Bloemraad et al., 1994, section 3.2.1). Moreover, the pH of pig meat 24 hours after slaughter varies from 5.8 to 6.2 , which is exactly within the most stable pH range.

Overall, virus in pig meat retains its infectivity for months if the meat is frozen. There is only one study on the decay of PRRS virus in meat when kept at $4^{\circ} \mathrm{C}$ (Bloemraad et al., 1994). Based on that study, the D-value (time taken to a 1 log reduction) for PRRS virus in meat kept at $4^{\circ} \mathrm{C}$ was estimated to be 30 hours (the virus titre in one virus positive sample of muscle decayed from $10^{3.7}$ to $10^{2.9}$ TCID $_{50}$ in 24 hours, and was undetectable after 48 hours).

\section{Conclusion:}

The decline in $\mathrm{pH}$ observed during carcass maturation does not impair the viability of PRRSv. The time period from slaughter to cutting takes a minimum of 30 hours and the use of fast or intensive cooling results in a quick reduction of the carcass temperature to $7^{\circ} \mathrm{C}$. Therefore, a minimum effect of maturation was estimated to be 1 log reduction of the amount of viable virus.

\section{Step 3c: Effect of de-boning and removal of lymph nodes}

Lymph nodes are main target organs for PRRSv. Therefore, the removal of lymph nodes will lower the amount of virus in the carcass of infected pigs. Since PRRSv does not replicate in bone marrow cells, de-boning is not expected to have an important impact on the total amount of infectious virus in the carcass (section 3.4.3). Moreover, de-boning has no effect on muscle $\mathrm{pH}$ or temperature (Klein, personal comment).

\section{Conclusion:}


Removal of lymph nodes will lower the amount of virus in the carcass of infected pigs. There is no anticipated reduction in the presence of PRRS virus in pig meat associated with de-boning carcasses.

\section{Step 4: Effect of transport and storage}

There is no decay of PRRS virus in meat when the meat is frozen (Benfield et al., 1992; Van Alstine et al., 1993; Bloemraad et al., 1994).

\section{Conclusion:}

PRRS virus present in frozen pig meat will not decay for weeks or months.

\section{Step 5: Effect of thawing on PRRS virus}

Meat transported frozen will eventually be thawed, and it is known that thawing has an effect on PRRS virus. Steverinck, (1999) found that the virus titres declined 0-2 log $\mathrm{TCID}_{50} / \mathrm{g}$ per freeze-thaw cycle. Likewise, van der Linden et al., (2003a) found 7 out of 12 samples were virus positive before freezing, but only 2 out of 12 samples positive after one freeze-thaw cycle. For the modelling, it was assumed that the freeze-thaw cycle would result in a 1-log reduction in the amount of virus present in pig meat.

\section{Conclusion:}

Thawing after freezing results in 1-log reduction in the amount of virus present in pig meat.

\section{Validation of the risk assessment estimate of pig meat contaminated with PRRS virus}

The estimated prevalence of PRRS virus in pig meat at the time of slaughter derived in this report (Step 2d) can be compared with results from field studies using blood and meat samples collected at abattoirs.

- Frey et al., (1995) reported, that 6 of 1049 (0.6\%) of abattoir meat samples were PRRS virus positive by virus isolation.

- Magar and Larochelle, (2004) reported that 45 out of 1039 (4.3\%) serum samples were PRRSv positive by PCR. Corresponding meat samples yielded 19 of $1027(1.9 \%)$ samples positive by PCR. Virus could be isolated in only one of the PCR-positive meat samples. Since PCR-based assays may react to both inactivated and infectious virus, bioassays were conducted on PCR-positive meat samples to confirm the presence of infectious virus. Eleven PCR-positive meat samples were fed to pigs and 7 were determined to contain infectious virus by bioassay. Adjusting for the proportion of samples determined to contain infectious virus on the basis of the bioassay results, the percent of meat samples estimated to contain infectious PRRS virus was $1.2 \%$. 
- A Danish study examined the presence of PRRS virus in pig meat from 22 herds where PRRS virus was active up to six months previously. In total, 234 pools of muscle samples were collected at slaughter from approximately ten pigs per herd. All samples were negative by virus isolation (Olsen, personal communication, 2005). The 234 pools originated from a population of 10,000 pigs, which corresponds to a $95 \%$ confidence interval for the prevalence ranging from 0.0 to $1.3 \%$ in the population.

The result of the present modelling indicates a prevalence of viraemia at slaughter of 1.9\%. Three different observational studies found that the prevalence of PRRSv in pig meat at slaughter varies from $0.0 \%$ to $1.2 \%$ (1.9\% when evaluated by use of PCR). Taking into account that the viral load in meat is two orders of magnitude lower than in blood, this may easily explain the differences between results obtained on serum and muscle, depending on the method applied. The procedures used for virus isolation on meat had lower detection limits of 2.4-2.8 $(\log 10)$ and thus would be expected to produce negative results in most cases where viraemic titres peaked at $10^{4}$ or below.

\section{Conclusion:}

The probability that a carcass randomly selected from a country with PRRS contains PRRSv at slaughter can be described as the probability of viraemia at the time of slaughter. This probability was estimated to be $1.9 \%$. The amount of PRRSv in meat following bleeding, maturation, de-boning, transport, and storage can be estimated from the level of viraemia, taking into account that bleeding, chilling, freezing and subsequent thawing will reduce the amount of virus by 2-4 $\log 10$. 
6. Risk Assessment for Risk Question 2: What is the probability that viable PRRS virus in pig meat reaches naive pigs?

\subsection{Description of pathway and associated probabilities leading to exposure of PRRS virus in pig meat to naive pigs}

Figure 6-1 describes the necessary pathway and the associated probabilities leading to the exposure of naive pigs to PRRS virus in pig meat (adapted from Murray, 2001). In the following the different steps in the pathway will be described.

Figure 6-1. Biological pathways for exposure of naive pigs to PRRSv in fresh pig meat

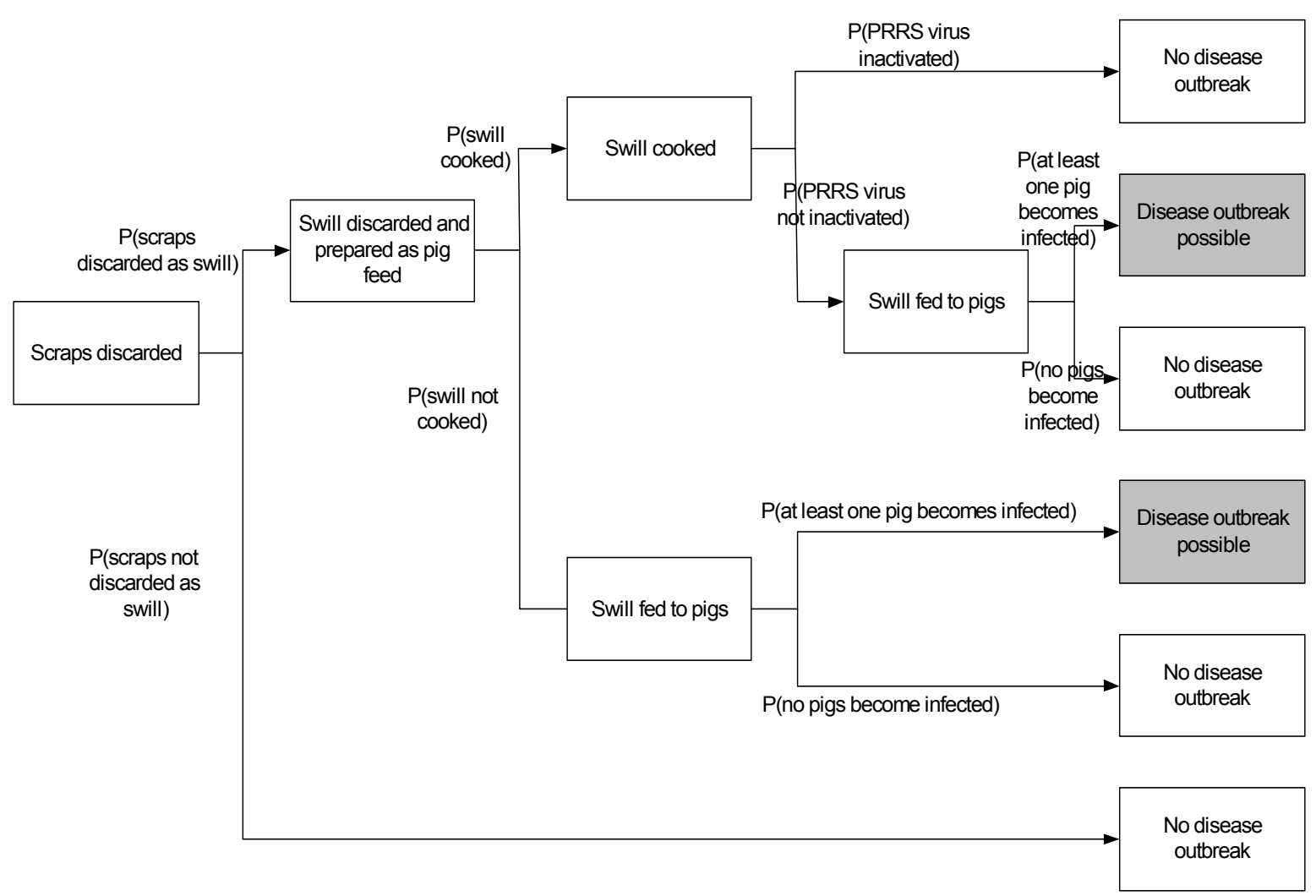

\section{Step 1: Scraps discarded}

National bans on the feeding of raw non heat-treated swill to pigs were implemented by several European countries following the introduction of African swine fever in Europe in the 1960ies. Community rules on swill feeding were adopted by Council Directive 80/217/EEC (EC, 1980) on the control of classical swine fever. In particular, catering waste from ships and aircrafts had to be collected and disposed of safely. Swill of other origin had to be heat treated so as to ensure the destruction of swine fever virus before feeding to pigs. Pigs fed such swill - in general fattening pigs - were prohibited from leaving the holding unless directly for slaughter.

Since 30 October 2002 feeding of heat-treated swill has been prohibited by the revised Council Directive 2001/89/EC (EC, 2001) on the control of Classical Swine Fever 
anticipating Regulation 1774/2002 (EC, 2002) on animal by-products, which introduced an intra-species recycling ban. Therefore even the feeding of heat-treated swill is now prohibited EU-wide, with a transitional exception for Austria and Germany. These two countries may still continue to feed pigs with swill that has undergone heat treatment under controlled conditions (officially approved facility and equipment, size reduction to $50 \mathrm{~mm}$, processing for 60 minutes at a core temperature of $90^{\circ} \mathrm{C}$ ) until 31 October 2006. However, the risk that raw swill may reach pigs as feed still cannot be totally excluded. Such an event will depend on many factors, e.g. infrastructure of pig meat production, national awareness and enforcement of these laws.

Pig meat may be discarded as scraps basically at 3 places: 1) meat manufacturer, 2) restaurants, and 3 ) households. It is assumed that meat manufacturing and processing facilities are adhering to a quality assurance scheme as a part of the factory's own control. This would imply that meat scraps are disposed of in a safe way and that the risk of scraps being fed to pigs therefore can be considered as negligible.

In general, restaurants and households may be expected to comply with current regulations on disposal of catering waste. In exceptional circumstances, however, restaurants and households might be assumed not to comply with regulations in force, leading to kitchen waste being discarded as swill and fed to pigs. To study the effect of such a scenario it was assumed that:

- A restaurant uses frozen pig meat originating from PRRS infected herds,

- $\quad 0.5 \mathrm{~kg}$ of fresh pig meat is discarded daily among the kitchen waste,

- The kitchen waste is left 16 hours at $25^{\circ} \mathrm{C}$ in a garbage bin,

- The restaurant has an agreement with a farmer about use of kitchen waste,

- The farmer collects kitchen waste from the restaurant daily,

- The farmer is a backyard producer and feeds the swill directly to 10 pigs without cooking.

A simulation model was set up in the software programme @Risk. The details of the model will be described in the following. In the model, distributions taking into account true variation and uncertainty were used whenever appropriate. The calculation is based on a total of $0.5 \mathrm{~kg}$ of raw meat being discarded. Around $1.9 \%$ of this originated from an infected carcass. The prevalence of PRRS virus in meat was described by an exponential curve with $b=0.019$ to allow for variation in prevalence. The amount of PRRSv present in pig meat was described by the use of an exponential distribution starting at $1 \mathrm{TCID}_{50}$ and with an average of $100 \mathrm{TCID}_{50}$ (Fig. 6-2). The effect of maturation was described by use of a 1-log reduction, which is the expected minimum effect of maturation on the amount of viable virus (step $3 \mathrm{~b}$ in chapter 5 ). The effect of thawing of frozen meat was described by use of a 1-log reduction, which is the expected average effect of thawing on the amount of viable virus (step 5 in chapter 5). 
Figure 6-2. Distribution of PRRSv present per $g$ in muscles of a viraemic pig

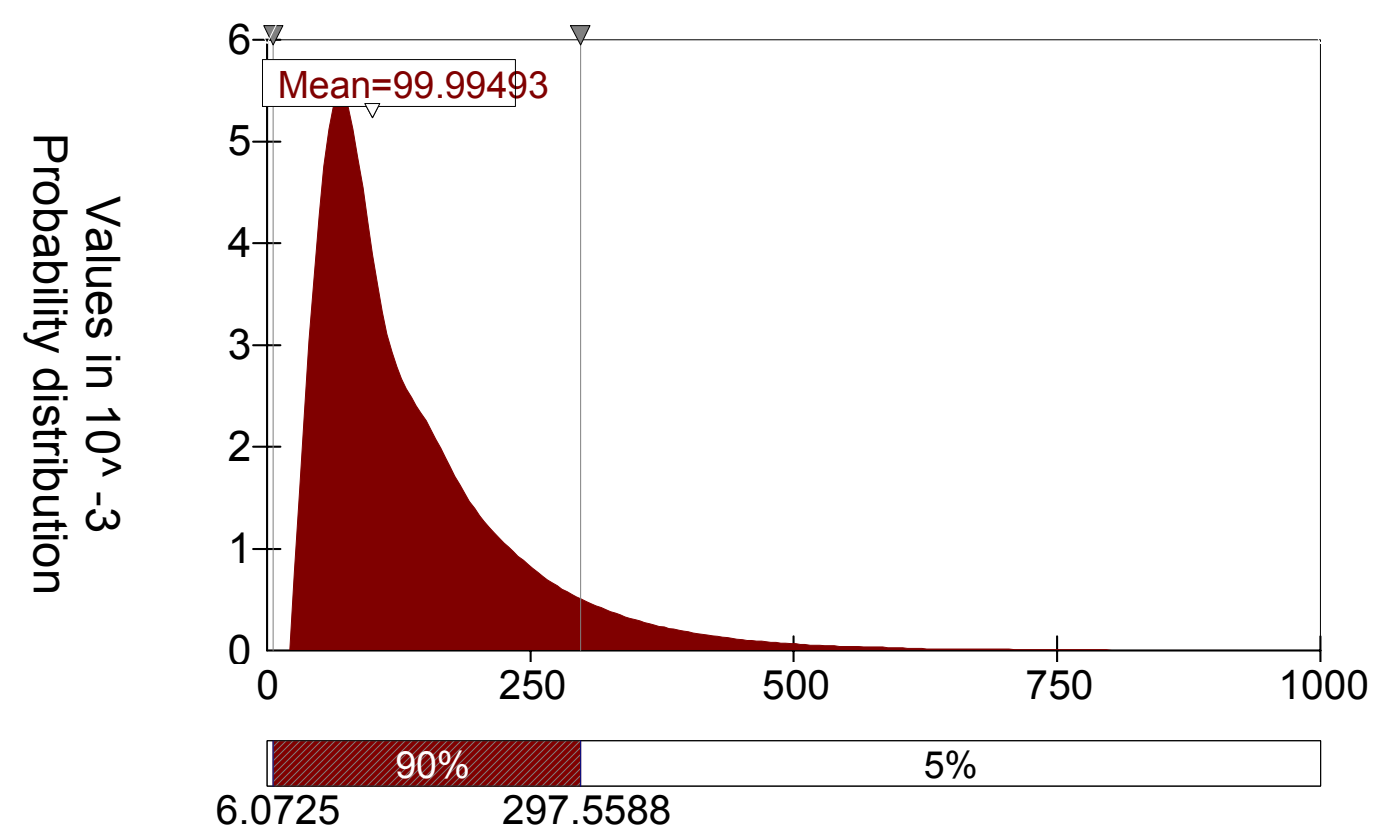

Figure 6.2. shows the distribution of PRRSv present per $g$ in muscles of a viraemic pig (exponential distribution, $b=99$, shift $=1$ )

\section{Step 2: Swill discarded and prepared as pig feed}

PRRS virus will decay when left at an ambient temperature of $25^{\circ} \mathrm{C}$. Based on data from Bloemraad et al., (1994) at D-value of 21 hours was estimated at $25^{\circ} \mathrm{C}$. This implies that after 16 hours - which was believed to be the minimum time between disposal and feeding - a decay of around $32 \%$ is expected.

Step 3: Swill cooked/not cooked - heat treated/non heat treated

Scraps can either be supplied raw or cooked. For the present scenario, it is assumed that scraps are discarded raw and fed directly to backyard pigs without further heat treatment. If cooking had been applied, the amount of PRRSv is assumed to be reduced to a negligible level. If heat treatment under controlled conditions is applied the virus is inactivated.

Step 4: Swill fed to pigs

It was assumed that a total of $500 \mathrm{~g}$ of swill originating from fresh pig meat would be fed to 10 pigs. Therefore, each pig would get $50 \mathrm{~g}$. 


\section{Scenario analysis}

According to the modelling, most servings of $50 \mathrm{~g},(68.0 \%)$ would contain less than 1 TCID $_{50}$ of PRRSv, however in some servings 1 (18.48\%), 2 (6.30\%), 3 (3.32\%), 4-9 (3.70\%), or $\geq 10(0.20 \%)$ TCID $_{50}$ would be present $(90 \%$ C.I. 0-3 TCID 50$)$, and in extreme cases up to 24 TCID $_{50}$ might be found.

In a realistic worst-case scenario, it may be assumed that all scraps originate from a carcass harbouring PRRSv at slaughter. This would result in a mean occurrence of 34 TCID $_{50}$ in a serving of $50 \mathrm{~g}(90 \%$ C.I.: 1-100).

In a less realistic scenario, it might be assumed that all scraps originated from a carcass harbouring PRRSv at slaughter - and that all $500 \mathrm{~g}$ were being fed to 1 pig. This would result in one pig being exposed to 340 TCID $_{50}(90 \%$ C.I.: 19-1,016).

The minimum oral infectious dose of PRRSv is not known. Most data on dose-response for PRRSv deal with other ways of transmission of infection than oral uptake. This makes it difficult to estimate the probability that the modelled doses would result in infection. However, the results can be compared with data presented in the literature on feeding pigs PRRSv-infected pig meat.

- van der Linden et al., (2003a) showed that feeding individual pigs $500 \mathrm{~g}$ meat originating from pigs slaughtered 11 days post-infection resulted in transmission of infection. The meat had been frozen and was thawed before feeding.

Magar and Larochelle, (2004) fed 11 PCR-positive meat samples, found in an abattoir study, to naive pigs. The meat samples weighed 1.05 to $1.8 \mathrm{~kg}$ each, and they were frozen and thawed before feeding. Each sample was cut into several pieces and fed to two pigs. Seven pig pairs were found to be infected by PRRSv following ingestion of meat samples.

These studies show that feeding of around $500 \mathrm{~g}$ of meat (that has been frozen and thawed) harbouring PRRSv to an individual pig may result in infection. This is true for meat from pigs experimentally infected and slaughtered at peak titre (11 days postinfection) as well as from naturally infected pigs slaughtered at normal slaughter age, where the time of infection is unknown. This corresponds to some degree to the scenario, where 1 pig received $500 \mathrm{~g}$ of meat, that all originated from a carcass with PRRSv, the only difference being that the experimental model did not include any decay due to being left at ambient temperature. It was modelled that 340 TCID $_{50}$ would be present in $500 \mathrm{~g}(90 \%$ C.I.: 19-1,016), assuming that any PRRSv present would decay with $32 \%$ due to being left at ambient temperature for at least 16 hours before being fed to pigs.

6.2. Conclusion on the probability of infecting a pig with PRRSv by oral exposure to infected pig meat

Oral infection by ingesting PRRSv-infected pig meat has been demonstrated experimentally. The minimal oral infectious dose is not known but the observation that meat containing PRRSv detectable by PCR but below the detection limit for virus isolation in vitro is still infectious suggests that the minimal infectious dose may be moderate or low. 
Historically, pig meat from PRRSv-infected countries has been imported into PRRSvfree countries in Europe and into New Zealand over the past decade without any evidence of dissemination of PRRSv. In most of these countries strict measures for treatment and disposal of animal waste were in place and this probably contributed significantly to the absence of transmission of PRRSv by that route. On the other hand, large amounts of pig meat from PRRSv-infected countries were for several years imported into New Zealand during a period where feeding of swill without any heat treatment was common practise and no infection with PRRSv has been reported. 


\section{Consequence assessment}

A consequence assessment deals with the kind and size of consequences that are related to the hazard of interest and the unwanted event hence for the purpose of this report with the introduction of PRRS into a country with a naive pig population.

PRRS is among the more costly infectious diseases of swine, but presents no known risk to humans or any other species. Therefore, the consequences are likely to be solely related to pig health and welfare. If PRRSv should be introduced extensively into a country with a naive pig population, the same series of events are expected as in other countries where PRRSv is now endemic. On the other hand, if the introduction of PRRSv is a sporadic event and if measures for early detection of infected herds are in place, the implementation of control measures might be able to limit the spread of the virus and possibly also result in its elimination from the country. The costs can be a result of direct or indirect consequences. These will be dealt with shortly in the following section. A more detailed assessment can only be conducted for a specific country - as it depends on the size and type of the national pig production.

\subsection{Direct consequences - in the pig herd}

The clinical disease of PRRS in a naive herd can be profound and has been described in detail elsewhere in this report. In its endemic form, disease presentation can vary greatly, and the losses sustained in the herds also differ. This is mainly due to the infection load of other production diseases in the herds. Herds that are declared free of specific production diseases and follow management programmes to ensure low infection load experience fewer production losses than conventional herds (Anon., 1994).

The losses related to PRRS might vary according to the production system. If PRRS becomes endemic it might represent a widespread problem for pig production with losses estimated up to $€ / \$ 5-15$ per infected pig.

It has been established that implementation of management programmes aimed ensuring a low infection load during an outbreak of PRRS, has a positive effect on the production rate during the endemic phase, sometimes of sufficient magnitude to outweigh the negative effects of the infection itself.

\subsection{Indirect consequences - trade}

According to the World Organisation for Animal Health (OIE), no special measures (including eradication) are required in relation to the introduction of PRRSv into a country (http://www.oie.int). So far, none of the countries affected by PRRS has chosen to eradicate the disease after introduction. The costs of controlling the disease (eradication, compensation, surveillance and control costs) vary depending on the measures employed against PRRS.

In the event that PRRSv is introduced into a country with a naive pig population and becomes endemic, restrictions in export to other countries would be expected to be the same as for other countries with PRRS. For those countries with PRRS, access to markets has not been denied, but importing countries may impose additional restrictions in connection with export. The financial impact of these restrictions on exports to specific markets depends on the kind of products exported, the volume and the price of the products. The restriction demands may either apply to all herds in the exporting country or to particular regions or herds. 


\section{Conclusion:}

The direct consequences associated with the introduction of PRRS are related to the production losses in the individual herd and the number of herds infected. Indirect consequences may include possible measures for prevention and control and restrictions of trade in live pigs, semen and pig meat. Certain countries may apply special requirements concerning PRRS status in connection with import of pig meat. The demands can cover either country freedom or herd freedom. 


\section{Overall risk estimation}

Based on the age-related pattern of incidence of PRRSv-infection in endemically infected populations and the tissue distribution of the virus during viraemia it is considered likely, that a small fraction of slaughter pigs will be replicating PRRSv at the time of slaughter. The lack of clear clinical or pathological signs of replication in slaughter-age pigs precludes detection by ante mortem and/or post mortem inspection.

Systematic use of live vaccines in young and growing pigs will lower the likelihood of viral presence in animals at the time of slaughter. Conversely, vaccine viruses present in slaughtered pigs could be a hazard to naive populations.

Maturation, chilling, and thawing of frozen meat will on average lead to $2 \log _{10}$ reduction of infectivity. Treatments such as de-boning or removal of lymph nodes will not be able to remove infectivity from carcasses.

The rate of inactivation of PRRSv is highly temperature-dependant, therefore the probability of survival of the virus in catering waste (swill) will depend on both ambient temperature and time before swill is actually being fed to pigs. The minimal oral infectious dose is not known but the observation that meat containing PRRSv detectable by PCR but below the detection limit for virus isolation in vitro suggests that the minimal infectious dose may be moderate or low. These factors, together with enforcement of controls prohibiting the use of non-heat treated swill for pig feed will determine the overall risk of exposure of pigs to PRRS-virus via possible, illegal feeding of swill. These factors will in every case be dependant on local conditions and are therefore not readily amenable to a generalised quantitative risk assessment.

The direct consequences associated with the introduction of PRRS are related to the production losses in the individual herd and the number of herds infected. Indirect consequences may include possible measures for prevention and control and restrictions of trade in live pigs, semen and pig meat.

Historically, pig meat from PRRSv-infected countries has been imported into PRRSvfree countries in Europe and New Zealand over the past decade without any evidence of dissemination of PRRSv. Thus, there is to date no documented field evidence to support or quantify the overall risk of importing PRRSv-infected meat. 


\section{Conclusions}

\subsection{Epidemiology}

PRRS is widespread in most of the world. Exceptions in Europe are Finland, Norway, Sweden, and Switzerland where active surveillance indicates that PRRS is not present. Likewise, PRRS has not been reported in New Zealand and Australia. Certain countries (e.g. Finland, Sweden, Norway) which have placed controls on importation of live animals and semen, yet still import large amounts of potentially infected meat, have not reported any cases of PRRS to date.

In PPRSv infected areas with intensive pig production and no specific control measures against PRRS, the prevalence is likely to range between 60 and $80 \%$. In areas of high pig density airborne spread of PRRSv may occur despite good biosecurity measures are in operation.

Within herd seroprevalence may vary, dependent on a number of factors including pig density, herd size and husbandry. PRRS virus usually infects weaners at an age of 5- to 12 weeks, occasionally up to 16 weeks. By the end of the finishing period, most pigs (around 80\%) are usually seropositive; however, the proportion of infected weaners varies between herds.

Long distance transmission of PRRS can occur as a result of movement of infected pigs or by use of semen from infected boars, whereas airborne transmission and mechanical vectors such as mosquitoes and flies will only enable local spread.

Transmission over long distances via infected pig meat remains a possibility and the probability of this occurring under natural conditions is the aim of the present risk assessment.

\subsection{Pathogenesis}

The clinical signs and pathology of acute PRRS are unlikely to be missed at a herd and regional level, when occurring in a previously free area. In the case of endemic PRRS clinical and pathological signs are less obvious and can easily be missed.

Given that the clinical signs and gross lesions can be variable or absent at individual and herd level, detection of disease by ante and post mortem examination at slaughter is unreliable.

PRRSv replication reaches a maximum during the first two weeks after inoculation with virus titres up to $10^{7-8} \mathrm{TCI} \mathrm{D}_{50} / \mathrm{g}$ in lungs, up to $10^{5-6} \mathrm{TCI} \mathrm{D}_{50} / \mathrm{g}$ in lymphoid tissues and 103-4 $\mathrm{TCID}_{50} / \mathrm{g}$ in serum and muscle. The onset of the specific immunity results in a reduction of virus replication between the third and sixth week after inoculation, leading in general to a full elimination of the virus.

PRRSv can persist in certain, specific tissues for prolonged periods following acute infection. These tissues include tonsil and certain other lymphoid tissue, and also lung and other pulmonary sites. The semen of infected boars can also yield virus for extended periods. There is no evidence of extended viraemia or recrudescence following viral clearance. 


\subsection{Virus stability}

The time period from slaughter to cutting takes a minimum of 30 hours and the use of fast or intensive cooling results in a quick reduction of the carcass temperature to $7^{\circ} \mathrm{C}$.

PRRSv is most stable between $\mathrm{pH}$ values 5.5 and 6.5 corresponding to the $\mathrm{pH}$ observed after carcass maturation.

PRRSv in pig meat retains its infectivity for months if the meat is frozen. Based on a single study, the D-value (time taken for $1 \log$ reduction of titre) for PRRSv in meat kept at $4^{\circ} \mathrm{C}$ was estimated to be 30 hours.

The proportion of lymphoid tissue in fresh meat cannot be quantified. Visible lymph nodes can be removed during the trimming process but this is done not necessarily and not systematically. Lymph nodes in locations not accessible during slaughter (within groups of muscles or viscera) will not be removed.

The use of live vaccines in young and growing pigs will reduce the amount of virus in pigs at the time of challenge and lower the likelihood of viral presence in animals at the time of slaughter. Vaccine viruses present in slaughtered pigs could be a hazard to naive populations.

\subsection{Diagnostic tests}

Diagnostic tests are reliable for determination of herd status. Tests which detect the viral genome are very sensitive but a positive result may not indicate the presence of infectious virus. Virus isolation is a reliable in vitro test for detection of viable virus in meat but an in vivo bioassay is the most sensitive.

RT-PCR tests are considered very sensitive; however the performance of RT-PCR testing among different laboratories may vary depending upon sample condition, sample matrices, sample processing, laboratory technique, and the skills and experience of the technician performing the assay.

\subsection{Hazard identification}

PPRS is a virus disease of pigs that is associated with loss of production and is widespread in most countries with intensive pig production. The most common ways of long distance transmission are via movement of infected live animals and semen. It has been speculated whether PRRSv can be transmitted via meat. Results of laboratory experiments indicate that this is possible. The question is how likely this is under natural conditions. Studies of presence of PRRS virus in slaughterhouses indicate a low prevalence of PRRSv in meat. However, before this meat can constitute a real risk, any virus has to survive maturation, storage and transport. Finally, viable virus must be ingested by a susceptible pig and be present in sufficient amount to result in infection. In considering the available evidence, we conclude that infectious PRRS virus in fresh pig meat may constitute a hazard when exported from a country or region with PRRS to a country with a naive pig population. 


\subsection{Release assessment}

Virus titres in muscle can be expected to be 100 times lower than those found in blood immediately after slaughter and bleeding. However, insufficient bleeding will significantly increase the amount of virus retained in muscle.

The decline in $\mathrm{pH}$ observed during carcass maturation does not impair the viability of PRRSv. The time period from slaughter to cutting takes a minimum of 30 hours and the use of fast or intensive cooling results in a quick reduction of the carcass temperature to $7^{\circ} \mathrm{C}$. Therefore, a minimum effect of maturation was estimated to be 1 log reduction of the amount of viable virus.

Removal of lymph nodes will lower the amount of virus in the carcass of infected pigs. There is no anticipated reduction in the presence of PRRS virus in pig meat associated with de-boning carcasses.

PRRSv present in frozen pig meat will not decay for weeks or months. Thawing results in 0-2 $\log _{10}$ reduction in the amount of virus present in pig meat.

The probability that a carcass randomly selected from a country with PRRS contains PRRSv at slaughter can be described as the probability of viraemia at the time of slaughter. This probability was estimated to be $1.9 \%$ (90\% C.I. 0.9-3.4\%). The amount of PRRSv in meat following bleeding, maturation, de-boning, transport, and storage can be estimated from the level of viraemia, taking into account that bleeding, chilling, freezing and subsequent thawing will reduce the amount of virus by 2-4 log10.

\subsection{Exposure assessment}

Oral infection by ingesting PRRSv-infected pig meat has been demonstrated experimentally. The minimal oral infectious dose is not known but the observation that meat containing PRRSv detectable by PCR but below the detection limit for virus isolation in vitro is still infectious suggests that the minimal infectious dose may be moderate or low. Several countries have imported pig meat from PRRSv infected countries. In most of them strict measures for treatment and disposal of animal waste were in place and this probably contributed significantly to the absence of transmission of PRRSv by that route.

\subsection{Consequence assessment}

The direct consequences associated with the introduction of PRRS are related to the production losses in the individual herd and the number of herds infected. Indirect consequences may include possible measures for prevention and control and restrictions of trade in live pigs, semen and pig meat. Certain countries may apply special requirements concerning PRRS status in connection with import of pig meat. The demands can cover either country freedom or herd freedom. 


\section{Recommendations}

Validation data of diagnostic tests should be provided in the context of their intended application. In particular, the value of PCR tests in determining infectious nature status of meat is unclear at this time and should be studied further.

The prevalence and quantity of PRRSv in carcasses of slaughter pigs should be studied in relation to relevant factors such as herd status, vaccination, bleeding efficiency, cooling etc.

The minimal infectious dose for oral exposure should be established. 


\section{References}

AASP subcommittee on PRRS. (1996). Laboratory diagnosis of porcine reproductive and respiratory syndrome (PRRS) virus infection. Swine Health and Production 4(1):33-35.

Albina, E. (1997). Epidemiology of porcine reproductive and respiratory syndrome (PRRS): an overview. Vet Microbiol 55, 309-16.

Albina, E., Leforban, Y., Baron, T., Duran, J.P., Vannier, P., and Plana-Duran J.(1992). An enzyme linked immunosorbent assay (ELISA) for the detection of antibodies to the porcine reproductive and respiratory syndrome (PRRS) virus. Annales de Recherches Veterinaires 23, 167-176.

Albina, E., Madec, F., Cariolet, R., Torrison, J. (1994). Immune response and persistence of the reproductive and respiratory syndrome virus in infected pigs and farm units. The Veterinary Record 134, 567-573.

Albina, E., Carrat, C. and Charley, B. (1998a). Interferon-alpha response to swine arterivirus (PoAV), the porcine reproductive and respiratory syndrome virus. J Interferon Cytokine Res 18, 485-90.

Albina, E., Piriou, L., Hutet, E., Cariolet, R. and L'Hospitalier, R. (1998b). Immune responses in pigs infected with porcine reproductive and respiratory syndrome virus (PRRSV). Vet Immunol Immunopathol 61, 49-66.

Alfonso, P., Frias-Lepoureau, M.T., 2003. PRRS in Central America and the Caribbean region. In: Zimmerman, J.J., Yoon, K.J. (editors), The PRRS Compendium $\left(2^{\text {nd }}\right.$ edition). National Pork Board, Des Moines lowa, pp. 217-220.

Allan, G.M., Ellis, J.A. (2000). Porcine circoviruses: a review. J Vet Diagn Invest 12, 3-14.

Allende, R., Kutish, G. F., Laegreid, W., Lu, Z., Lewis, T.L., Rock, D.L., Friesen, J., Galeota, J.A., Doster, A.R., and Osorio, F.A.(2000). Mutations in the genome of porcine reproductive and respiratory syndrome virus responsible for the attenuation phenotype. Archives of Virology 145, 1149-1161.

Amass, S.F. and Clark, L.K.(1999). Biosecurity considerations for pork production units. Swine Health and Production 7, 217-228.

Anon. (1994). Report - Project South. An examination of clinical symptoms, serological profile, consequences on production and financial impact of clinical outbreaks of PRRS in herds in southern Jutland (in Danish). The National Committee for Pig Production, Denmark

Anon (1997). Prevalence of PRRS virus in the United States. APHIS: VS NAHMS Info Sheet N225.197.

Anon (2005). SPF-Denmark, Annual Report 2003-2004. 24 pp. Bjørn Lorenzen, Director of SPF-SUS Denmark.

Balasuriya, U.B., Leutenegger, C.M., Topol, J.B., McCollum, W.H., Timoney, P.J. and MacLachlan, N.J. (2002). Detection of equine arteritis virus by real-time TaqMan reverse transcription-PCR assay. J Virol Methods 101, 21-8.

Bautista, E.M, Goyal, S., Yoon, I., Joo, H.S. (1992). Comparison of swine alveolar macrophages and cell line 2621 for the detection of SIRS virus and its antibody. American Association of Swine Practitioners Newsletter 4, 32-36.

Bautista, E.M., Goyal, S.M., Yoon, I.J., Joo, H.S., Collins, J.E. (1993). Comparison of porcine alveolar macrophages and CL 2621 for the detection of porcine reproductive and respiratory syndrome (PRRS) virus and anti PRRS antibody. Journal of Veterinary Diagnostic Investigation 5, 163-165. 
Bautista, E.M., Molitor, T.W. (1997). Cell-mediated immunity to porcine reproductive and respiratory syndrome virus in swine. Viral Immunol 10, 83-94.

Bautista, E.M., Suarez, P. and Molitor, T.W. (1999). T cell responses to the structural polypeptides of porcine reproductive and respiratory syndrome virus. Arch Virol 144, 117-34.

Benfield, D.A., Nelson, E., Collins, J.E., Harris, L., Goyal, S.M., Robison, D., Christianson, W.T., Morrison, R.B., Gorcyca, D., and Chladek, D. (1992a). Characterization of swine infertility and respiratory syndrome (SIRS) virus (isolate ATCC VR-2332). Journal of Veterinary Diagnostic Investigation 4, 127-133.

Benfield, D.A., Nelson, E.A., Christopher-Hennings, J. (1994). Porcine reproductive and respiratory syndrome (PRRS) viral proteins and antigenic variation. Proceedings of the $13^{\text {th }}$ International Pig Veterinary Congress, Bangkok, Thailand, 26 ${ }^{\text {th }}-30^{\text {th }}$ June 1994. 62.

Benson, J.E., Yaeger, M.J., Christopher-Hennings, J., Lager, K. and Yoon, K.J. (2002). A comparison of virus isolation, immunohistochemistry, fetal serology, and reversetranscription polymerase chain reaction assay for the identification of porcine reproductive and respiratory syndrome virus transplacental infection in the fetus. J Vet Diagn Invest 14, 8-14.

Beutling, D. (1992) Fleisch. In: Fehlhaber, K., Janetschke, P. (Ed.): Veterinärmedizinische Lebensmittelhygiene. Gustav Fischer Verlag Jena, pp. 191241

Beyer, J., Fichtner, D., Schirrmeier, H., Polster, U., Weiland, E. and Wege, H. (2000). Porcine reproductive and respiratory syndrome virus (PRRSV): kinetics of infection in lymphatic organs and lung. J Vet Med B Infect Dis Vet Public Health 47, 9-25.

Bierk, M.D., Dee, S.A., Rossow, K.D., Collins, J.E., Guedes, M.I., and Molitor, T. W. (2000). Experiences with tonsil biopsy as an antemortem diagnostic test for detecting porcine reproductive and respiratory syndrome virus infection in breeding swine. Swine Health and Production 8, 279-282.

Bierk, M.D., Dee, S.A., Rossow, K.D., Collins, J.E., Guedes, M.I., Pijoan, C. and Molitor, T.W. (2001). Diagnostic investigation of chronic porcine reproductive and respiratory syndrome virus in a breeding herd of pigs. Vet Rec 148, 687-90.

Bilodeau, R., Archambault, D., Vezina, S. A., Sauvageau, R., Fournier, M., and Dea, S. (1994). Persistence of Porcine Reproductive and Respiratory Syndrome VirusInfection in a Swine Operation. Canadian Journal of Veterinary Research 58, 291298.

Blaha, T. (1992). Epidemiological investigations into PEARS in Germany: Consequences in fattening pigs. In: Proceedings of the $12^{\text {th }}$ Congress of the International Pig Veterinary Society, The Hague, Netherlands, pp 126.

Bloemraad, M., de Kluijver, E.P., Petersen, A., Burkhardt, G., Wensvoort, G. (1994). Porcine reproductive and respiratory syndrome: Temperature and $\mathrm{pH}$ stability of Lelystad virus and its survival in tissue specimens from viraemic pigs. Veterinary Microbiology 42, 361-371.

Botner, A. (1997). Diagnosis of PRRS. Vet Microbiol 55, 295-301.

Brockmeier, S.L., Lager, K.M. (2002). Experimental airborne transmission of porcine reproductive and respiratory syndrome virus and Bordetella bronchiseptica. Vet Microbiol 89, 267-75.

Busse, F., Alt, M., Janthur, I., Neumann, W., Schoss, P. (1991). Epidemiological studies on porcine reproductive and respiratory syndrome (PRRS) in the area of Weser Ems (North West Germany). Tierärztliche Umschau. 46, 708-717. 
Carlson, D.L., Fang, Y., Nelson, E.A., Christopher-Hennings, J. (2002). Discriminating between PRRSv isolates and vaccine with quantitative, real-time RT-PCR. Proceedings of the American Association of Veterinary Laboratory Diagnosticians.

Cheon, D.S., Chae, C. (2000). Comparison of virus isolation, reverse transcriptionpolymerase chain reaction, immunohistochemistry, and in situ hybridization for the detection of porcine reproductive and respiratory syndrome virus from naturally aborted fetuses and stillborn piglets. J Vet Diagn Invest 12, 582-7.

Cho, H.J., Mc Nab, B., Dubuc, C., Jordan, L., Afshar, A., Magar, R., Prins, S. and Eernisse, K. (1997) Comparative study of serological methods for the detection of antibodies to porcine reproductive and respiratory syndrome virus.

Can J Vet Res; 61(3): 161-6.

Christianson, W.T., Choi, C.S., Collins, J.E., Molitor, T.W., Morrison, R.B., and Joo, H.S. (1993). Pathogenesis of porcine reproductive and respiratory syndrome virus infection in mid-gestation sows and fetuses. Canadian Journal of Veterinary Research 57, 262-268.

Christianson, W.T., Joo, H.S. (1994). Porcine reproductive and respiratory syndrome: A review. Swine Health and Production 2, 10-28.

Christianson, W.T., Collins, J.E., Benfield, D.A., Harris, L., Gorcyca, D.E., Chladek, D.W., Morrison, R.B. and Joo, H.S. (1992). Experimental reproduction of swine infertility and respiratory syndrome in pregnant sows. American Journal of Veterinary Research. 53, 485-488.

Christopher-Hennings, J., Holler, L.D., Benfield, D.A. and Nelson, E.A. (2001). Detection and duration of porcine reproductive and respiratory syndrome virus in semen, serum, peripheral blood mononuclear cells, and tissues from Yorkshire, Hampshire, and Landrace boars. J Vet Diagn Invest 13, 133-42.

Christopher-Hennings, J., Nelson, E.A., Nelson, J.K., Rossow, K.D., Shivers, J.L., Yaeger, M.J., Chase, C.C., Garduno, R.A., Collins, J.E. and Benfield, D.A. (1998). Identification of porcine reproductive and respiratory syndrome virus in semen and tissues from vasectomized and nonvasectomized boars. Vet Pathol 35, 2607.

Christopher-Hennings, J., Nelson, E.A., Nelson, J.K. and Benfield, D.A. (1997). Effects of a modified-live virus vaccine against porcine reproductive and respiratory syndrome in boars. Am J Vet Res 58, 40-5.

Christopher-Hennings, J., Nelson, E.A., Nelson, J.K., Hines, R.J., Swenson, S.L., Hill, H.T., Zimmerman, J.J., Katz, J.B., Yaeger, M.J., Chase, C.C. and others (1995b). Detection of porcine reproductive and respiratory syndrome virus in boar semen by PCR. J Clin Microbiol 33, 1730-4.

Christopher-Hennings, J., Nelson, E.A., Hines, R.J., Nelson, J.K., Swenson, S.L., Zimmerman, J.J., Chase, C.L., Yaeger, M.J. and Benfield, D.A. (1995a). Persistence of porcine reproductive and respiratory syndrome virus in serum and semen of adult boars. J Vet Diagn Invest 7, 456-64.

Chung, W.B., Chan, W.H., Chaung, H.C., Lien, Y., Wu, C.C. and Huang, Y.L. (2005). Realtime PCR for quantitation of porcine reproductive and respiratory syndrome virus and porcine circovirus type 2 in naturally-infected and challenged pigs. J Virol Methods 124, 11-9.

Chung, W.B., Lin, M.W., Chang, W.F., Hsu, M. and Yang, P.C. (1997). Persistence of porcine reproductive and respiratory syndrome virus in intensive farrow-to-finish pig herds. Can J Vet Res 61, 292-8. 
Ciacci-Zanella, J.R., Trombetta, C., Vargas, I. (2004). Lack of evidence of porcine reproductive and respiratory syndrome virus (PRRSv) infection in domestic swine in Brazil. Cięncia Rural 34:449-455.

Collins, J.E., Benfield, D.A., Christianson, W.T., Harris, L., Hennings, J.C., Shaw, D.P., Goyal, S.M., McCullough, S., Morrison, R.B., Joo, H.S., Gorcyca, D., and Chladek, D. (1992). Isolation of swine infertility and respiratory syndrome virus (isolate ATCC VR-2332) in North America and experimental reproduction of the disease in gnotobiotic pigs. Journal of Veterinary Diagnostic Investigation 4, 117-126.

Danish Bacon \& Meat Council, Copenhagen, Finn Udesen, personal communication.

Danish efficacy recording system (2004), Danish Bacon \& Meat Council.

De Jong, M.F., VanT'Veld, P., Cromwijk, W. (1991). The epidemiology of PRRS in the Netherlands. Report of the Second Seminar of the EC on Porcine Reproductive and Respiratory Syndrome (the new pig disease), Brussels, Belgium, 4-5 November 1991 PVET/EN/0207-5, 2-7.

Dea, S., Bilodeau, R., Athanaseous, R., Sauvageau, R., Martineau, G. (1992). PRRS (porcine reproductive and respiratory syndrome) syndrome in Quebec: isolation of a virus serologically related to Lelystad virus. Veterinary Record. 130, 167.

Dea, S., Gagnon, C. A., Mardassi, H., Pirzadeh, B., and Rogan, D. (2000) Current knowledge on the structural proteins of porcine reproductive and respiratory syndrome (PRRS) virus: comparison of the North American and European isolates. Archives of Virology 145[4], 659-688.

Dee, S. A. and Joo, H. S. (1994a). Recurrent Reproductive Failure Associated with Porcine Reproductive and Respiratory Syndrome in a Swine Herd. Journal of the American Veterinary Medical Association 205, 1017-1018.

Dee, S. A. and Joo, H. S. (1994b). Prevention of the spread of porcine reproductive and respiratory syndrome virus in endemically infected pig herds by nursery depopulation. Veterinary Record 135, 6-9.

Dee, S. A., Joo, H. S., and Pijoan, C. (1994). Control of Porcine Reproductive and Respiratory Syndrome Virus Transmission - Handling Infected Seedstock. Compendium on Continuing Education for the Practicing Veterinarian 16, 927.

Dee, S. A., Joo, H. S., Henry, S., Tokach, L., Park, B. K., Molitor, T.W., and Pijoan, C. (1996). Detecting Subpopulations after PRRS Virus-Infection in Large Breeding Herds Using Multiple Serologic Tests. Swine Health and Production 4, 181-184.

Dee, S. A. and Joo, H. S. (1997). Strategies to control PRRS: A summary of field and research experiences. Veterinary Microbiology 55, 347-353.

Dee, S. A., Deen, J., Rossow, K.D., Wiese, C., Otake, S., Joo, H.S. and Pijoan, C. (2002). Mechanical transmission of porcine reproductive and respiratory syndrome virus throughout a coordinated sequence of events during cold weather. Can J Vet Res 66, 232-9.

Delputte, P.L., Vanderheijden, N., Nauwynck, H.J. and Pensaert, M.B. (2002). Involvement of the matrix protein in attachment of porcine reproductive and respiratory syndrome virus to a heparinlike receptor on porcine alveolar macrophages. J Virol 76, 4312-20.

Delputte, P.L., Nauwynck, H.J. (2004). Porcine arterivirus infection of alveolar macrophages is mediated by sialic acid on the virus. J Virol 78, 8094-101.

Delputte, P. L., Costers, S. and Nauwynck, H. J. (2005). Analysis of porcine reproductive and respiratory syndrome virus attachment and internalization: distinctive roles for heparan sulphate and sialoadhesin. J Gen Virol 86:1441-5.

DMRI, Danish meat research institute, http://www.danskeslagterier.dk/smcms/SF_forside/Index.htm?ID=211 
Denac, H., Moser, C., Tratschin, J.D., Hofmann, M.A. (1997) An indirect ELISA for the detection of antibodies against porcine reproductive and respiratory syndrome virus using recombinant nucleocapsid protein as antigen. J Virol Methods. 65(2):169-81.

Dewey, C. (1998). The Porcine Reproductive and Respiratory Syndrome Panzootic. Compendium on Continuing Education for the Practicing Veterinarian 20, 82.

Dewey, C., Charbonneau, G., Carman, S., Hamel, A., Nayar, G., Friendship, R., Eernisse, K. and Swenson, S. (2000). Lelystad-like strain of porcine reproductive and respiratory syndrome virus (PRRSV) identified in Canadian swine. Can Vet J 41, 493-4.

Dewey, C., Wilson, S., Buck, P. and Leyenaar, J.K. (2004). Effects of porcine reproductive and respiratory syndrome vaccination in breeding-age animals. Prev Vet Med 62, 299-307.

Donadeu, M., Arias, M., Gomez-Tejedor, C., Aguero, M., Romero, L.J., Christianson, W.T., and Sanchez Vizcaino, J.M. (1999). Using polymerase chain reaction to obtain PRRSV-free piglets from endemically infected herds. Swine Health and Production 7, 255-261.

Done, S.H., Paton, D.J., Edwards, S., Brown, I., White, M.E.C., Robertson, I. (1992). Porcine reproductive and respiratory syndrome ("blue-eared" pig disease). Pig Veterinary Journal 28, 9-23.

Done, S.H. and Paton, D.J. (1995). Porcine reproductive and respiratory syndrome: Clinical disease, pathology and immunosuppression. Veterinary Record 136, 3235.

Done, S.H., Spencer, Y., Paton, D.J., Drew, T.W., Hannam, D., Higgins, R., Twiddy, N., Simmons, J.R., White, M.E.C. (1996). The pathology of natural infections with porcine reproductive and respiratory syndrome virus (PRRSV) in the UK. Pig Veterinary Journal 36, 18-30.

Drew, T.W. (1995). Comparative serology of porcine reproductive and respiratory syndrome in eight European laboratories, using immunoperoxidase monolayer assay and enzyme-linked immunosorbent assay. Rev Sci Tech 14, 761-75.

Duan, X., Nauwynck, H.J. and Pensaert, M.B. (1997a). Effects of origin and state of differentiation and activation of monocytes/macrophages on their susceptibility to porcine reproductive and respiratory syndrome virus (PRRSV). Arch Virol 142, 2483-97.

Duan, X., Nauwynck, H.J. and Pensaert, M.B. (1997b). Virus quantification and identification of cellular targets in the lungs and lymphoid tissues of pigs at different time intervals after inoculation with porcine reproductive and respiratory syndrome virus (PRRSV). Vet Microbiol 56, 9-19.

EC, (1964) Council Directive 64/433/EEC of 26 June 1964 on health conditions for the production and marketing of fresh meat (OJ L 121, 29.7.94, p.2012).

EC, (1980) Council Directive 80/217/EEC of 22 January 1980 introducing Community measures for the control of classical swine fever ( $O J L 47,21.2 .1980, p .11$ )

EC, (2001) Council Directive 2001/89/EC of 23 October 2001 on Community measures for the control of classical swine fever (OJ L 316, 1.12.2001, p. 5)

EC, (2004) Regulation of the European Parliament and of the Council (EC) No 853/2004 of 29 April 2004 laying down specific hygiene rules for on the hygiene of foodstuffs (OJ L 139, 30.4.2004, p. 55).

Edwards, S., Robertson, I., Wilesmith, J., Ryan, J., Kilner, C., Paton, D.J., Drew T.W., Brown, I., Sands, J. (1992). PRRS ("Blue-eared pig disease") in Great Britain. American Association of Swine Practitioners Newsletter 4(4), 32-36. 
Egli, C., Thur, B., Liu, L. and Hofmann, M.A. (2001). Quantitative TaqMan RT-PCR for the detection and differentiation of European and North American strains of porcine reproductive and respiratory syndrome virus. J Virol Methods 98, 63-75.

Farez, S. and Morley, R. S. (1997). Potential animal health hazards of pork and pork products. Revue Scientifique et Technique de L'Office International Des Epizooties 16, 65-78.

Ferrin, N., Fang, Y., Carroll, J. (2002). Validation of a blocking ELISA for antibodies against PRRSv. Proceedings of the International Pig Veterinary Society Congress, p. 365.

Ferrin, N.H., Fang, Y., Johnson, C.R., Murtaugh, M.P., Polson, D.D., Torremorell, M., Gramer, M.L., and Nelson, E.A. (2004). Validation of a blocking enzyme-linked immunosorbent assay for detection of antibodies against porcine reproductive and respiratory syndrome virus. Clinical and Diagnostic Laboratory Immunology 11, 503-514.

Fichtner, D., Bergmann, S., Schirrmeier, H. (1994). Einsatz des eindirekten Immunfluoreszenztests zum Nachweis von Antikörpern gegen das Virus des Porcine Reproductive and Respiratory Syndrome (PRRS). Mh. Vet.-Med 49: 223227.

Fichtner et al., Foss, D.L., Zilliox, M.J., Meier, W., Zuckermann, F. and Murtaugh, M.P. (2002). Adjuvant danger signals increase the immune response to porcine reproductive and respiratory syndrome virus. Viral Immunol 15, 557-66.

Frey, M.L., Landgraf, J.G., Schmitt, B.J., Eernisse, K.A., Pearson, J.E. (1995). Recovery of porcine reproductive and repiratory syndrome virus from tissues of slaughter weight pigs. Abstracts of the Second International Symposium on Porcine Reproductive and Respiratory Syndrome (PRRS), Copenhagen, Denmark, August $9^{\text {th }}-10^{\text {th }}, 1995.28$.

Frey, M.L., Eernisse, K., Landgraf, J., Pearson, J., Chladek, D. (1992). Diagnostic testing for sirs virus at the national veterinary services laboratories (NVSL). American Association of Swine Practitioners Newsletter 4, 31.

Garner, M.G., Gleeson, L.J., Holyoake, P.K., Cannon, R.M. and Doughty, W.J. (1997). A national serological survey to verify Australia's freedom from porcine reproductive and respiratory syndrome. Aust Vet J 75, 596-600.

Geue, A. (1995). Prevalence and incidence of the porcine reproductive and respiratory syndrome in a district of Schleswig-Holstein Germany. Untersuchungen zur Prävalenz und Inzidenz des Porcinen Reproductive and Respiratory Syndrome (PRRS) in einem Kreis Schleswig-Holstein. Fachbereich Veterinärmedizin, Freie Universität, Berlin, Germany.

Goldberg, T.L., Weigel, R.M., Hahn, E.C. and Scherba, G. (2000). Associations between genetics, farm characteristics and clinical disease in field outbreaks of porcine reproductive and respiratory syndrome virus. Prev Vet Med 43, 293-302.

Goyal, S.M. (1993) Porcine reproductive and respiratory syndrome. J Vet Diagn Invest.; 5(4):656-64.

Halbur, P.G., Paul, P.S., Meng, X., Andrews, J.J. (1992). Reproduction of proliferative interstitial pneumonia (PIP) and myocarditis with tissue filtrates from a case of epidemic pneumonia in nursery pigs. Proceedings of the $12^{\text {th }}$ Congress of the International Pig Veterinary Society, The Hague, Netherlands, 17-20 th August, 1992. 130.

Halbur, P.G., Paul, P.S., Janke, B.H. (1993). Viral contributors to the porcine respiratory disease complex. Proceedings of the $24^{\text {th }}$ Annual Meeting of the American Association of Swine Practitioners, Kansas City, Missouri, USA 343-350. 
Halbur, P.G., Meng, P.X., Hagemoser, W. (1994a). Marked variability in pathogenicity of nine US porcine reproductive and respiratory syndrome virus (PRRSV) isolates in 5-week -old CDCD pigs. Proceedings of the $13^{\text {th }}$ International Pig Veterinary Congress, Bangkok, Thailand, 26 ${ }^{\text {th }}-30^{\text {th }}$ June 1994. 59.

Halbur, P.G., Paul, P.S., Andrews, J.J. (1994b). Development of a streptavidin-biotin immunoperoxidase procedure for the detection of porcine reproductive and respiratory syndrome virus (PRRSV) antigen in porcine tissues. Proceedings of the $13^{\text {th }}$ International Pig Veterinary Congress, Bangkok, Thailand, 26 ${ }^{\text {th }}-30^{\text {th }}$ June 1994. 60.

Halbur, P.G., Miller, L.D., Paul, P.S., Meng, X.J., Huffman, E.L. and Andrews, J.J. (1995). Immunohistochemical identification of porcine reproductive and respiratory syndrome virus (PRRSV) antigen in the heart and lymphoid system of three-weekold colostrum-deprived pigs. Vet Pathol 32, 200-4 .

Halbur, P.G., Paul, P. S., Frey, M. L., Landgraf, J., Eernisse, K., Meng, X. J., Andrews, J. J., Lum, M. A., and Rathje, J. A.(1996a). Comparison of the antigen distribution of 2 US porcine reproductive and respiratory syndrome virus isolates with that of the Lelystad-virus. Veterinary Pathology 33, 159-170.

Halbur, P.G., Paul, P.S., Meng, X.J., Lum, M.A., Andrews, J.J. and Rathje, J.A. (1996b). Comparative pathogenicity of nine US porcine reproductive and respiratory syndrome virus (PRRSV) isolates in a five-week-old cesarean- derived, colostrumdeprived pig model. J Vet Diagn Invest 8, 11-20.

Halbur, P.G., Pallares, F.J., Rathje, J.A., Evans, R., Hagemoser, W A., Paul, P.S., and Meng, X.J. (2002). Effects of different us isolates of porcine reproductive and respiratory syndrome virus (PRRSV) on blood and bone marrow parameters of experimentally infected pigs. Veterinary Record 151, 344.

Haynes, J.S., Halbur, P.G., Sirinarumitr, T., Paul, P.S., Meng, X.J. and Huffman, E.L. (1997). Temporal and morphologic characterization of the distribution of porcine reproductive and respiratory syndrome virus (PRRSV) by in situ hybridization in pigs infected with isolates of PRRSV that differ in virulence. Vet Pathol 34, 39-43.

Hill, H. (1990). Overview and history of Mystery Swine Disease (Swine Infertility and Respiratory Syndrome). In: Proceedings of the Mystery Swine Disease Committee Meeting, October 6, 1990, Denver Colorado. Livestock Conservation Institute, Madison WI, USA.

Hirose, O., Kudo, H., Yoshizawa, S., Hiroike, T., Nakane, T. (1995). Prevalence of porcine reproductive and respiratory syndrome virus in Chiba prefecture. J Jpn Vet Med Assoc 48:650-653.

Hoefling, D. C., (1990). Mystery swine disease. In: Ninety-fourth Annual Meeting of the United States Animal Health Association pp 501-504.

Honikel, K.O. (1996) Fleischbehandlung. In: Stiebing, A., Barciaga, J., Krell, U. M., Wirth, F. (Ed.): Handbuch Fleisch und Fleischwaren. Kapitel A 4.3.1, Behr's Verlag, Hamburg, pp. 1-4

Hooper, C.C., van Alstine, W.G., Stevenson, G.W. and Kanitz, C.L. (1994). Mice and rats (laboratory and feral) are not a reservoir for PRRS virus. J Vet Diagn Invest 6, 135.

Horter, D., Chang, C.C., Pogranichnyy, R., Zimmerman, J.J. and Yoon, K.J. (2001). Persistence of porcine reproductive and respiratory syndrome in pigs. Adv Exp Med Biol 494, 91-4.

Horter, D.C., Pogranichniy, R.M., Chang, C.C., Evans, R.B., Yoon, K.J. and Zimmerman, J.J. (2002). Characterization of the carrier state in porcine reproductive and respiratory syndrome virus infection. Vet Microbiol 86, 213-28. 
Houben, S., Callebaut, P. and Pensaert, M.B. (1995a). Comparative study of a blocking enzyme-linked immunosorbent assay and the immunoperoxidase monolayer assay for the detection of antibodies to the porcine reproductive and respiratory syndrome virus in pigs. J Virol Methods 51, 125-8.

Houben, S., Vanreeth, K., and Pensaert, M.B. (1995b). Pattern of infection with the porcine reproductive and respiratory syndrome virus on swine farms in Belgium. Journal of Veterinary Medicine Series B - Zentralblatt Fur Veterinarmedizin Reihe B - Infectious Diseases and Veterinary Public Health 42, 209-215.

Howerth, E.W., Murphy, M.D. and Roberts, A.W. (2002). Failure of porcine reproductive and respiratory syndrome virus to replicate in porcine endothelial cell cultures. $J$ Vet Diagn Invest 14, 73-6.

Indik S, and Valicek L. (2002). Differentiation of porcine reproductive and respiratory syndrome virus European vaccine strains from Czech field isolates by restriction fragment length polymorphism analysis of ORF5 gene. Vet Med Czech. 47, 295301.

Janutenaite, J., Lager, K.M., Stabel, T., Pesch, B. and Brockmeier, S.L. (2002). Evaluation of immune response induced by attenuated and wild-type PRRS virus. In: Proceedings of the $17^{\text {th }}$ Congress of the International Pig Veterinary Society, Ames, lowa, USA,

Johnson, W., Roof, M., Vaughn, E., Christopher-Hennings, J., Johnson, C.R. and Murtaugh, M.P. (2004). Pathogenic and humoral immune responses to porcine reproductive and respiratory syndrome virus (PRRSV) are related to viral load in acute infection. Vet Immunol Immunopathol 102, 233-47.

Joo HS. (1993). PRRS: Diagnosis. Proceedings of the Allen D. Leman Swine Conference, pp. 53-55.

Keffaber, K.K. (1989). Reproductive failure of unknown etiology. American Association of Swine Practitioners Newsletter 1, 1-10.

Keffaber, K.K., Stevenson, G.W., Van Alstine, W.G., Kanitz, C., Harris L, Gorcyca D, Schlesinnger, K., Schultz, R., Chadek, D., Morrison, R.M. (1992). SIRS virus infection in nursery/grower pigs. American Association of Swine Practitioners Newsletter 4, 38-40.

Kim, H.S., Kwang, J., Yoon, I.J., Joo, H.S. and Frey, M.L. (1993). Enhanced replication of porcine reproductive and respiratory syndrome (PRRS) virus in a homogeneous subpopulation of MA-104 cell line. Arch Virol 133, 477-83.

Kleiboeker, S.B., Lehman, J.R., and Fangman, T.J. (2002). Concurrent use of reverse transcription-polymerase chain reaction testing of oropharyngeal scrapings and paired serological testing for detection of porcine reproductive and respiratory syndrome virus infection in sows. Journal of Swine Health and Production 10, 251-258.

Kleiboeker, S.B., Schommer, S.K., Lee, S.M., Watkins, S., Chittick, W. and Polson, D.J., (2005) Vet Diagn Invest. Mar; 17(2):165-70. Simultaneous detection of North American and European porcine reproductive and respiratory syndrome virus using real-time quantitative reverse transcriptase-PCR.

Komijn, R.E., van Klink, E.G., Van Sande, W.J.H., (1991). The possible effect of weather conditions on the spread of the 'new' pig disease in the Netherlands. The new pig disease. Porcine respiration and reproductive syndrome. A report on the seminar/workshop held in Brussels on 29-30 April 1991 and organized by the European Commission (Directorate-General for Agriculture). 1991, 28-31; 2 ref. Brussels, Belgium; European Commission. 
Krassnig, G., Krassnig, R., Grammer, H. and Schweighardt, H. (1994). Occurrence of the Porcine Reproductive and Respiratory Syndrome (PRRS) in Austria - Case-Report. Wiener Tierärztliche Monatsschrift 81, 285-289.

Kristensen, C.S., Boetner, A., Takai, H., Nielsen, J.P. and Jorsal, S.E. (2004). Experimental airborne transmission of PRRS virus. Veterinary microbiology 99, 197-202.

Labarque, G.G., Nauwynck, H.J., Van Reeth, K. and Pensaert, M.B. (2000b). Effect of cellular changes and onset of humoral immunity on the replication of porcine reproductive and respiratory syndrome virus in the lungs of pigs. J Gen Virol 81, 1327-34.

Labarque, G., Van Gucht, S., Nauwynck, H.J., Van Reeth, K. and Pensaert, M.B. (2003). Apoptosis in the lungs of pigs infected with porcine reproductive and respiratory syndrome virus and associations with the production of apoptogenic cytokines. Vet Res 34, 249-60.

Labarque, G., Van Reeth, K., Nauwynck, H.J., Drexler, C., Van Gucht S and Pensaert, M.B. (2004). Impact of genetic diversity of European-type porcine reproductive and respiratory syndrome virus strains on vaccine efficacy. Vaccine 22, 4183-90.

Lager, K.M., Mengeling, W.L. and Brockmeier, S.L. (1997). Homologous challenge of porcine reproductive and respiratory syndrome virus immunity in pregnant swine. Vet Microbiol 58, 113-25.

Lager, K.M., Mengeling, W.L. and Brockmeier, S.L. (1999). Evaluation of protective immunity in gilts inoculated with the NADC-8 isolate of porcine reproductive and respiratory syndrome virus (PRRSV) and challenge-exposed with an antigenically distinct PRRSV isolate. Am J Vet Res 60, 1022-7.

Larochelle, R., Magar, R. (1995). Comparison of immunogold silver staining (IGSS) with two immunoperoxidase staining systems for the detection of porcine reproductive and respiratory syndrome virus (PRRSV) antigens in formalin-fixed tissues. J Vet Diagn Invest 7, 540-3.

Larochelle, R., Magar, R. (1997). Evaluation of the presence of porcine reproductive and respiratory syndrome virus in packaged pig meat using virus isolation and polymerase chain reaction (PCR) method. Vet Microbiol 58, 1-8.

Le Potier, M.F., Blanquefort, P., Morvan, E. and Albina, E. (1997). Results of a control programme for the porcine reproductive and respiratory syndrome in the French 'Pays de la Loire' region. Vet Microbiol 55, 355-60.

Lee, C., Rogan, D., Erickson, L., Zhang, J. and Yoo, D. (2004). Characterization of the porcine reproductive and respiratory syndrome virus glycoprotein 5 (GP5) in stably expressing cells. Virus Res 104, 33-8.

Loemba, H.D., Mounir, S., Mardassi, H., Archambault, D. and Dea, S. (1996). Kinetics of humoral immune response to the major structural proteins of the porcine reproductive and respiratory syndrome virus. Arch Virol 141, 751-61.

Lopez Fuertes, L., Domenech, N., Alvarez, B., Ezquerra, A., Dominguez, J., Castro, J.M. and Alonso, F. (1999). Analysis of cellular immune response in pigs recovered from porcine respiratory and reproductive syndrome infection. Virus Res 64, 3342.

Lu, C., Lim, K.I., Hahn, T.W. (1999). Seroprevalence of ELISA antibody to porcine reproductive and respiratory syndrome virus in Korea. Annals of Animal Resources Science 10, 127-137.

Ludemann, L.R., Magar, R. (2004). Porcine Reproductive and Respiratory Syndrome. In: OIE Manual of Diagnostic Tests and Vaccines for Terrestrial Animals (mammals, 
birds and bees), Fifth Edition, Paris, France: Office International des Epizooties , Chapter 2.6.5. 802-815.

Madsen, K.G., Hansen, C.M., Madsen, E.S., Strandbygaard, B., Botner, A. and Sorensen, K.J. (1998). Sequence analysis of porcine reproductive and respiratory syndrome virus of the American type collected from Danish swine herds. Arch Virol 143, 1683-700.

Maes, D. (1997). Descriptive epidemiological aspects of the seroprevalence of five respiratory disease agents in slaughter pigs from fattening herds. Epidemiol Santé Animal 31 32, 19.

Magar, R. and Larochelle, R. (2004). Evaluation of the presence of porcine reproductive and respiratory syndrome virus in pig meat and experimental transmission following oral exposure. Can J Vet Res 68, 259-66.

Magar, R., Larochelle, R., Dea, S., Gagnon, C.A., Nelson, E.A., Christopher-Hennings, J. and Benfield, D.A. (1995a). Antigenic comparison of Canadian and US isolates of porcine reproductive and respiratory syndrome virus using monoclonal antibodies to the nucleocapsid protein. Can J Vet Res 59, 232-4 .

Magar, R., Robinson, Y., Dubuc, C. and Larochelle, R. (1995b). Evaluation of the persistence of porcine reproductive and respiratory syndrome virus in pig carcases. Vet Rec 137, 559-61.

Mardassi, H., Athanassious, R., Mounir, S. and Dea, S. (1994). Porcine reproductive and respiratory syndrome virus: morphological, biochemical and serological characteristics of Quebec isolates associated with acute and chronic outbreaks of porcine reproductive and respiratory syndrome. Can J Vet Res 58, 55-64.

Martin, T. (1999) The animal health status of Tokelau. http://www.spc.int/rahs/PAHIS/Countries/AH\%20Status\%20of\%20Tokelaue.ht m

Mateusen, B., Maes, D., Nauwynck, H.J. (2002). Seroprevalence of porcine reproductive and respiratory syndrome virus (PRRSV) in 20 Belgian farrow-to-finish pig herds. Proceedings of the International Pig Veterinary Society Congress 2, 240.

Meier, W.A. Wheeler J. Husmann R.J. Osorio F.A. and Zuckermann F.A., (2000). Characteristics of the immune response of pigs to wild-type PRRS virus or to commercially available vaccines: an unconventional response. In: Proceedings of the American Association of Swine Practitioners, Indianapolis, Indiana, USA, pp 415-418.

Meier, W., Galeota, J., Husmann, R.J., Osorio, F., and Zuckermann, F.A. (2002) Characteristics of the cell-mediated immune response of swine to porcine reproductive and respiratory syndrome virus. Trends in Emerging Viral Infections of Swine. 355-358. 2002. 2121 S State Ave/Ames/IA 50010/USA, lowa State Univ Press.

Meng, X.J. (2000). Heterogeneity of porcine reproductive and respiratory syndrome virus: implications for current vaccine efficacy and future vaccine development. Vet Microbiol 74, 309-29.

Meng, X.J., Paul, P.S. and Halbur, P.G. (1994). Molecular cloning and nucleotide sequencing of the 3'-terminal genomic RNA of the porcine reproductive and respiratory syndrome virus. J Gen Virol 75 (Pt 7), 1795-801.

Meng, X.J., Paul, P.S., Halbur, P.G. and Lum, M.A. (1996). Characterization of a highvirulence US isolate of porcine reproductive and respiratory syndrome virus in a continuous cell line, ATCC CRL 11171 . J Vet Diagn Invest 8, 374-81. 
Mengeling, W.L., Paul, P.S., and Lager, K.M. (1993). Virus induced maternal reproductive failure of swine. Journal of the American Veterinary Medical Association 203, 1268.

Mengeling, W.L., Lager, K.M., and Vorwald, A.C. (1994). Temporal characterization of transplacental infection of porcine fetuses with porcine reproductive and respiratory syndrome virus. American Journal of Veterinary Research 55, 13911398.

Mengeling, W.L., Lager, K.M., and Vorwald, A.C. (1995). Diagnosis of porcine reproductive and respiratory syndrome. Journal of Veterinary Diagnostic Investigation 7, 3-16.

Mengeling, W.L., Lager, K.M., and Vorwald, A.C. (2000). The effect of porcine parvovirus and porcine reproductive and respiratory syndrome virus on porcine reproductive performance. Animal Reproduction Science 60, 199-210.

Meredith, M.J. (1995a). Porcine Reproductive and Respiratory Syndrome (PRRS). 1. European Edition. Pig Disease Information Centre, Department of Clinical Veterinary Medicine, University of Cambridge, UK. August 1995: Boehringer Ingelheim Vetmedica GmbH.

Meredith, M.J. (1995b). Porcine Reproductive and Respiratory Syndrome (PRRS). 2nd North American Edition. Pig Disease Information Centre, Department of Clinical Veterinary Medicine, University of Cambridge, UK. May 1995: NOBL Laboratories.

Meulenberg, J.J., Petersen den Besten, A., de Kluyver, E., van Nieuwstadt, A., Wensvoort, G. and Moormann, R.J. (1997). Molecular characterization of Lelystad virus. Vet Microbiol 55, 197-202.

Miller, L.C., Fox, J.M. (2004). Apoptosis and porcine reproductive and respiratory syndrome virus. Vet Immunol Immunopathol 102, 131-42.

Molitor, T.W., Xiao, J. and Choi, C.S. (1996). PRRS virus infection of macrophages: regulation by maturation and activation state. In: Proceedings of the American Association of Swine Practitioners Nashville, Tennessee, USA, pp 563.

Molitor, T.W., Bautista, E.M. and Choi, C.S. (1997a). Immunity to PRRSV: double-edged sword. Vet Microbiol 55, 265-76.

Molitor, T. W., Tune, K. A., Shin, J., Collins, J.E. and Kapur, V. (1997b). Applications of TaqMan TM PCR in the detection of porcine reproductive and respiratory virus. In: Proceedings of the Allen D. Leman Swine Conference. University of Minnesota, pp 173-175.

Morrison, R.B., Collins, J.E., Harris, L., Chladek, D.W., Gorcyca, D.E., Joo, H.S., Christianson, W., Benfield, D.A., Marsh, W.E., Goyal, S., Annelli, J.F. (1992b). Seroepidemiological investigation of porcine reproductive and respiratory syndrome (PEARS, PRRS, SIRS). Proceedings of the $12^{\text {th }}$ Congress of the International Pig Veterinary Society, The Hague, Netherlands, 17-20th August, 1992. 114.

Mortensen, S., Madsen, K.G. (1992). The occurrence of PRRS in Denmark. American Association of Swine Practitioners News 4, 48-52.

Mortensen, S., Strandbygaard, B., Botner, A., Feld, N. and Willeberg, P. (2001). Monitoring porcine reproductive and respiratory syndrome virus infection status in swine herds based on analysis of antibodies in meat juice samples. Vet Res 32, 441-53.

Mortensen, S., Stryhn, H., Sogaard, R., Boklund, A., Stark, K.D.C., Christensen, J., and Willeberg, P.(2002). Risk factors for infection of sow herds with porcine reproductive and respiratory syndrome (PRRS) virus. Preventive Veterinary Medicine 53, 83-101. 
Motha, J., Stark, K., Thompson, J. (1997). New Zealand is free from PRRS, TGE, and PRCV. Surveillance 24, 10-11.

Murray, N. (2001) Draft import risk analysis: Porcine Reproductive and Respiratory Syndrome Virus in chilled or frozen pig meat. Risk Analysis, Animal Biosecurity, Biosecurity Authority, Ministry of Agriculture and Forestry, New Zealand.

Murtaugh, M.P., Elam, M.R. and Kakach, L.T. (1995). Comparison of the structural protein coding sequences of the VR-2332 and Lelystad virus strains of the PRRS virus. Arch Virol 140, 1451-60.

Nauwynck, H.J., Favoreel, H.W., Van Oostveldt, P. and Pensaert, M.B. (1999 ). Entry of porcine reproductive and respiratory syndrome virus into porcine alveolar macrophages via receptor-mediated endocytosis. Journal of General Virology 80, 297-305.

Nielsen, H.S., Oleksiewicz, M.B., Forsberg, R., Stadejek, T., Botner, A. and Storgaard, T. (2001). Reversion of a live porcine reproductive and respiratory syndrome virus vaccine investigated by parallel mutations. J Gen Virol 82, 1263-72.

Nielsen, T., Nielsen, J., Have, P., Baekbo, P., Hofjorhensen, R., Boetner, A. (1997). Examination of virus shedding in semen from vaccinated and from previously infected boars aftere experimental challenge with porcine reproductive and respiratory syndrome virus. Veterinary Microbiology 54, 101-112.

Nodelijk, G., Wensvoort, G., Kroese, B., van Leengoed, L., Colijn, E. and Verheijden, J. (1996). Comparison of a commercial ELISA and an immunoperoxidase monolayer assay to detect antibodies directed against porcine respiratory and reproductive syndrome virus. Vet Microbiol 49, 285-95.

Nodelijk, G., DeJong, M.C.M., VanNes, A., Vernooy, J.C.M., VanLeengoed, L.A.M.G., Pol, J. M.A., and Verheijden, J.H.M. (2000). Introduction, persistence and fade-out of porcine reproductive and respiratory syndrome virus in a Dutch breeding herd: a mathematical analysis. Epidemiology and Infection 124, 173-182.

Nowotny, N., Möstl, K., Maderbacher, R. (1994). Serological studies in Austrian fattening pigs with respiratory disorders. Acta Vet Hung 42, 377-379.

OIE, 2004a: Guidelines for Import Risk Analysis. Chapter 1.3.2. In: Terrestrial Animal Health Code. $13^{\text {th }}$ edition. World Organisation for Animal Health, Paris, France, Health, Paris, France.

OIE, 2004b, Manual of Diagnostic Tests and Vaccines for Terrestrial Animals, $5^{\text {th }}$. Edition, World Organization for Animal Health, Paris, France.

O'Connor, M., Fallon, M., and O'Reilly, P. J. (2002). Detection of antibody to porcine reproductive and respiratory syndrome (PRRS) virus: reduction of cut-off value of an ELISA, with confirmation by immunoperoxidase monolayer assay. Irish Veterinary Journal 55, 73-75.

Ohlinger, V., Haas, B., Sallmuller, A., Beyer, J., Teuffert, J., Visser, N., Weiland, F. (1992). In vivo and in vitro studies on the immunobiology of PRRS. American Association of Swine Practitioners Newsletter 4 (4), 24.

Olsen, A.M. (2005) from the Danish Bacon \& Meat Council in Copenhagen, personal communication

Ortner, H. (1988) Einfluß der Kühlung auf die Fleischqualität. Fleischwirtsch. 68, 794796

Otake, S., Dee, S.A., Rossow, K.D., Deen, J., Joo, H.J., Molitor, T.W., Pijoan, C. (2002). Transmission of porcine repproductive and respiratory syndrome virus by fomites (boots and coveralls). Journal of Swine Health and Production 10, 59-65. 
Otake, S., Dee, S.A., Rossow, K.D., Moon, R.D., Trincado, C. and Pijoan, C. (2003). Transmission of porcine reproductive and respiratory syndrome virus by houseflies (Musca domestica) Vet Rec 152, 73-6.

Paton, D.J., Brown, I. H., Scott, A. C., Done, S. H. and Edwards, S. (1992a). Isolation of a Lelystad virus like agent from British pigs and scanning electron microscopy of infected macrophages. In: Proceedings of the Second Congress of the European Society for Veterinary Virology Uppsala, Sweden, pp 195-201.

Paton, D.J., Drew T.W., Brown, I.H., Edwards, S., and Done, S.H. (1992b). Laboratory diagnosis of porcine reproductive and respiratory syndrome. Pig Veterinary Journal 29: 188-192.

Park, B.K., Joo, H.S., Dee, S.A., Pijoan C. (1995). Evaluation of an indirect fluorescent IgM antibody test for the detection of pigs with recent infection of porcine reproductive and respiratory syndrome virus. J Vet Diagn Invest 7:544-546.

Perfumo, C.J. and Sanguinetti, H.R. (2003). Argentina: Serological studies on PRRS virus. In: Zimmerman J.J., Yoon, K.J. (editors), The PRRS Compendium (2 ${ }^{\text {nd }}$ edition). National Pork Board, Des Moines lowa, pp. 209-211.

Pirtle, E.C. and Beran, G.W. (1996). Stability of porcine reproductive and respiratory syndrome virus in the presence of fomites commonly found on farms. J Am Vet Med Assoc 208, 390-2.

Pol, J.M.A. and Wagenaar, F. (1992). Morphogenesis of Lelystad virus in porcine alveolar macrophages. American Association of Swine Practitioners Newsletter 4, 29.

Pol, J.M.A., van Dijk, J.E., Wensvoort, G., and Terpstra, C. (1991). Pathological, ultrastructural, and immunohistochemical changes caused by Lelystad virus in experimentally induced infections of mystery swine disease (synonym: porcine epidemic abortion and respiratory syndrome (PEARS). Veterinary Quarterly 13, 137-143.

Pol, J.M.A., Wagenar, F., Broekhuijsen-Davies, J., Wensvoort, G. (1992). The morphogenesis of Lelystad virus in porcine lung alveolar macrophages. Proceedings of the 12th Congress of the International Pig Veterinary Society, The Hague, Netherlands, 17-20 th August, 1992. 127.

Pol, J.M.A., Wagenaar, F. and Reus, J.E. (1997). Comparative morphogenesis of three PRRS virus strains. Vet Microbiol 55, 203-8.

Prieto, C., Suarez, P., Bautista, J.M., Sanchez, R., Rillo, S.M., Simarro, I., Solana, A., and Castro, J. M. (1996a). Semen changes in boars after experimental-infection with porcine reproductive and respiratory syndrome (PRRS) virus. Theriogenology 45, 383-395.

Prieto, C., Suarez, P., MartinRillo, S., Simarro, I., Solana, A., and Castro, J.M. (1996b). Effect of porcine reproductive and respiratory syndrome virus (PRRSV) on development of porcine fertilized ova in vitro. Theriogenology 46, 687-693.

Prieto, C., Suarez, P., Simarro, I., Garcia, C., Fernandez, A. and Castro, J.M. (1997). Transplacental infection following exposure of gilts to porcine reproductive and respiratory syndrome virus at the onset of gestation. Vet Microbiol 57, 301-11.

Ramirez, M.H., Milo, R.A., Carreón, N.R., (2002). Participation of backyard and Mexican hairless pigs in the transmission of some viral diseases in the state of Chiapas, Mexico. Proceedings of the International Pig Veterinary Society Congress 2:416.

Reuter, G. (1996) Mikrobiologie des Fleisches. In: Weber, H. (Ed.): Mikrobiologie der Lebensmittel - Fleisch und Fleischerzeugnisse. Behr's Verlag, Hamburg, pp. 3115 
Robertson, I. (1992). Porcine reproductive and respiratory syndrome (blue eared pig disease): some aspects of its epidemiology. Proceedings of Society for Veterinary Epidemiology and Preventive Medicine, Edinburgh, 1-3 April 1992, pp 24-38.

Ropp, S. L., Wees, C.E.M., Fang, Y., Nelson, E.A., Rossow, K.D., Bien, M., Arndt, B., Preszler, S., Steen, P., Christopher-Hennings, J., Collins, J.E., Benfield, D.A., and Faaberg, K.S. (2004). Characterization of emerging European-like porcine reproductive and respiratory syndrome virus isolates in the United States. Journal of Virology 78, 3684-3703.

Rossow, K.D. (1998). Porcine reproductive and respiratory syndrome. Vet Pathol 35, 120.

Rossow, K.D., Bautista, E.M., Goyal, S.M., Molitor, T.W., Murtaugh, M.P., Morrison, R.B., Benfield, D.A., and Collins, J.E. (1994a). Experimental Porcine Reproductive and Respiratory Syndrome Virus Infection in One-Week-Old, 4-Week-Old, and 10Week-Old Pigs. Journal of Veterinary Diagnostic Investigation 6, 3-12.

Rossow, K.D., Morrison, R.B., Goyal, S.M., Singh, G.S., and Collins, J.E. (1994b). LymphNode Lesions in Neonatal Pigs Congenitally Exposed to Porcine Reproductive and Respiratory Syndrome Virus. Journal of Veterinary Diagnostic Investigation 6, 368-371.

Rossow, K.D., Collins, J.E., Goyal, S.M., Nelson, E.A., Christopher-Hennings, J. and Benfield, D.A. (1995). Pathogenesis of porcine reproductive and respiratory syndrome virus infection in gnotobiotic pigs. Vet Pathol 32, 361-73.

Rossow, K.D., Laube, K.L., Goyal, S.M. and Collins, J.E. (1996). Fetal microscopic lesions in porcine reproductive and respiratory syndrome virus-induced abortion. Vet Pathol 33, 95-9.

Rossow, K.D., Shivers, J.L., Yeske, P.E., Polson, D.D., Rowland, R.R., Lawson, S.R., Murtaugh, M.P., Nelson, E.A. and Collins, J.E. (1999). Porcine reproductive and respiratory syndrome virus infection in neonatal pigs characterised by marked neurovirulence. Vet Rec 144, 444-8.

Rowland, R.R., Kervin, R., Kuckleburg, C., Sperlich, A. and Benfield, D.A. (1999). The localization of porcine reproductive and respiratory syndrome virus nucleocapsid protein to the nucleolus of infected cells and identification of a potential nucleolar localization signal sequence. Virus Res 64, 1-12.

Rutherford, M.S., Witsell, A., Schook, L.B. (1993). Mechanism generating functionally heterogeneous macrophages: chaos revisited. Journal of Leukocyte Biology 53, 602-618.

Savell, J. W., Mueller, S. L., Baird, B. E. (2004). The chilling of carcasses. $50^{\text {th }}$ IcoMST Helsinki, Finland.

Saville, P. (1999) The animal health status of Palau. http://www.spc.int/rahs/PAHIS/Countries/AH\%20Status\%20of\%20Palaue.htm

Seuberlich, T., Tratschin, J.D., Thur, B. and Hofmann, M.A. (2002). Nucleocapsid protein-based enzyme-linked immunosorbent assay for detection and differentiation of antibodies against European and North American porcine reproductive and respiratory syndrome virus. Clin Diagn Lab Immunol 9, 1183-91.

Shibata, I., Mori, M., Uruno, K., Samegai, Y. and Okada, M. (1997). In vivo replication of porcine reproductive and respiratory syndrome virus in swine alveolar macrophages and change in the cell population in bronchoalveolar lavage fluid after infection. J Vet Med Sci 59, 539-43.

Shimizu, M., Yamada, S., Kawashima, K., Ohashi, S., Shimizu, S. and Ogawa, T. (1996). Changes of lymphocyte subpopulations in pigs infected with porcine reproductive and respiratory syndrome (PRRS) virus. Vet Immunol Immunopathol 50, 19-27. 
Shin, J.H., Molitor, T.W. (2002). Localization of porcine reproductive and respiratory syndrome virus infection in boars by in situ riboprobe hybridization. J Vet Sci 3, 87-96.

Sierra, N., Ramirez, R., and Mota, D. (2000). Isolation of PRRS virus in Mexico: A clinical, serological and virological study . Archivos de Medicina Veterinaria 32, 19.

Snyder, M.L., Mermer, B., Anderson, P.R., Wensvoort, G., Hill, H.T. (1995). Evaluative data for an immunological ELISA for PRRS. Abstracts of the Second International Symposium on Porcine Reproductive and Respiratory Syndrome (PRRS), Copenhagen, Denmark, August $9^{\text {th }}-10^{\text {th }}, 1995.15$.

Sorensen, K.J., Botner, A., Madsen, E.S., Strandbygaard, B. and Nielsen, J. (1997). Evaluation of a blocking Elisa for screening of antibodies against porcine reproductive and respiratory syndrome (PRRS) virus. Vet Microbiol 56, 1-8.

Sorensen, K.J., Strandbygaard, B., Botner, A., Madsen, E.S., Nielsen, J. and Have, P. (1998). Blocking ELISA's for the distinction between antibodies against European and American strains of porcine reproductive and respiratory syndrome virus. Vet Microbiol 60, 169-77.

Spagnuolo-Weaver, M., McNeilly, F., Allan, G., Walker, I., Foster, C., and Adair, B. (1998). Evaluation of RT-PCR and virus isolation for the diagnosis of porcine reproductive and respiratory syndrome. Irish Veterinary Journal 51, 136-136.

Stadejek, T., Stankevicius, A., Storgaard, T., Oleksiewicz, M.B., Belak, S., Drew, T.W. and Pejsak, Z. (2002). Identification of radically different variants of porcine reproductive and respiratory syndrome virus in Eastern Europe: towards a common ancestor for European and American viruses. J Gen Virol 83, 1861-73.

Stevenson, G., Alstine, W.V., Kanitz, C., Keffaber, K., Van, A.W. (1993). Endemic porcine reproductive and respiratory syndrome virus infection of nursery pigs in two swine herds without current reproductive failure. Journal of Veterinary Diagnostic Investigation. 5, 432-434.

Steverinck, P. (1999). Internal Report, Study 807-47041-00-99-09. ID-Lelystad, the Netherlands.

Storgaard, T., Oleksiewicz, M. and Botner, A. (1999). Examination of the selective pressures on a live PRRS vaccine virus. Arch Virol 144, 2389-401.

Suarez, P., Diaz-Guerra, M., Prieto, C., Esteban, M., Castro, J.M., Nieto, A. and Ortin, J. (1996). Open reading frame 5 of porcine reproductive and respiratory syndrome virus as a cause of virus-induced apoptosis. J Virol 70, 2876-82.

Sur, J.H., Doster, A.R., Christian, J.S., Galeota, J.A., Wills, R.W., Zimmerman, J.J. and Osorio, F.A. (1997). Porcine reproductive and respiratory syndrome virus replicates in testicular germ cells, alters spermatogenesis, and induces germ cell death by apoptosis. J Virol 71, 9170-9.

Swenson, S.L., Hill, H.T., Zimmerman, J.J., Evans, L.E., Landgraf, J.G., Wills, R.W., McGinley, M., Brevik, A., Ciszewski, D., Frey, M.L. (1994a). PEARS in experimentally infected boars. Proceedings of the 13th International Pig Veterinary Congress, Bangkok, Thailand, 26th-30th June 1994. 58.

Swenson, S. L., Hill, H. T., Zimmerman, J. J., Evans, L. E., Landgraf, J. G., Wills, R.W., Sanderson, T. P., Mcginley, M. J., Brevik, A. K., Ciszewski, D. K., and Frey, M. L. (1994b). Excretion of porcine reproductive and respiratory syndrome virus in semen after experimentally induced infection in boars. Journal of the American Veterinary Medical Association 204, 1943-1948. 
Takashima, H., Takai, K., Goto, S. (1999). A modified immunoperoxidase assay for detection of antibody porcine reproductive and respiratory syndrome (PRRS) virus in swine sera. J. Vet. Med. Sci. 61: 105-196.

Takikawa, N., Kobayashi, S., Ide, S., Yamane, Y., Tanaka, Y. and Yamagishi, H. (1996). Detection of antibodies against porcine reproductive and respiratory syndrome (PRRS) virus in swine sera by enzyme-linked immunosorbent assay. J Vet Med Sci 58, 355-7.

Taylor, A.C. (1997). Titration of heparinase for the removal of the PCR-inhibitory effect of heparine in DNA samples. Mol. Ecology 6; 383-385.

Teifke, J.P., Dauber, M., Fichtner, D., Lenk, M., Polster, U., Weiland, E. and Beyer, J. (2001). Detection of European porcine reproductive and respiratory syndrome virus in porcine alveolar macrophages by two-colour immunofluorescence and insitu hybridization-immunohistochemistry double labelling. J Comp Pathol 124, 238-45.

Thacker, B. (1992). Serological surveys in a herd before, during and after an outbreak of SIRS. American Association of Swine Practitioners Newsletter 4, 40.

Thanawongnuwech, R., Halbur, P.G. and Andrews, J.J. (1997). Immunohistochemical detection of porcine reproductive and respiratory syndrome virus antigen in neurovascular lesions. J Vet Diagn Invest 9, 334-7.

Torremorell, M., Pijoan, C., Janni, K., Walker, R., and Joo, H.S.(1997). Airborne transmission of Actinobacillus pleuropneumoniae and porcine reproductive and respiratory syndrome virus in nursery pigs. American Journal of Veterinary Research 58, 828-832.

Torremorell M, Polson D, Henry SC, Morrison RB. 2002. Specificity of the PRRSV IDEXX ELISA test in negative farms. Proceedings of the International Pig Veterinary Society Congress 1:209.

Torrison, J., Vannier, P., Albina, E., Madec, F., Morrison, R.B. (1994). Incidence and clinical effect of PRRS virus infection in gilts on commercial swine farms. Proceedings of the $13^{\text {th }}$ International Pig Veterinary Congress, Bangkok, Thailand, $26^{\text {th }}$-30th June 1994. 511.

Van Alstine, W.G., Kanitz, C.L. and Stevenson, G.W. (1993). Time and temperature survivability of PRRS virus in serum and tissues. J Vet Diagn Invest 5, 621-2.

van der Linden, I.F., van der Linde-Bril, E.M., Voermans, J.J., van Rijn, P.A., Pol, J.M.A., Martin, R. and Steverink, P.J. (2003a). Oral transmission of porcine reproductive and respiratory syndrome virus by muscle of experimentally infected pigs. Vet Microbiol 97, 45-54.

van der Linden, I.F., Voermans, J.J., van der Linde-Bril, E.M., Bianchi, A.T. and Steverink, P.J. (2003b). Virological kinetics and immunological responses to a porcine reproductive and respiratory syndrome virus infection of pigs at different ages. Vaccine 21, 1952-7.

van Reeth, K., Labarque, G., Nauwynck, H.J., and Pensaert, M.B. (1999). Differential production of proinflammatory cytokines in the pig lung during different respiratory virus infections: correlations with pathogenicity. Res Vet Sci 67, 4752.

van Rijn, P.A., Wellenberg, G.J., Hakze-van der Honing, R., Jacobs, L., Moonen, P.L. and Feitsma, H. (2004). Detection of economically important viruses in boar semen by quantitative RealTime PCR technology. J Virol Methods 120, 151-60.

Vanderheijden, N., Delputte, P.L., Favoreel, H.W., Vandekerckhove, J., Van Damme, J., van Woensel, P.A. and Nauwynck, H.J. (2003). Involvement of sialoadhesin in 
entry of porcine reproductive and respiratory syndrome virus into porcine alveolar macrophages. J Virol 77, 8207-15.

Vezina, S.A., Loemba, H., Fournier, M., Dea, S. and Archambault, D. (1996). Antibody production and blastogenic response in pigs experimentally infected with porcine reproductive and respiratory syndrome virus. Can J Vet Res 60, 94-9.

Vogel, K., Kramer, M., Leuffert, J., Kramer, S., (1991). PRRS - Epidemiological and economic analyses in Germany. Report of the Second Seminar of the EC on Porcine Reproductive and Respiratory Syndrome (the new pig disease), Brussels, Belgium, 4-5 November 1991. PVET/EN/0207, 49-52.

Wagstrom, E.A., Yoon, K.J., Cook, C. and Zimmerman, J.J. (2000). Diagnostic performance of a reverse transcription-polymerase chain reaction test for porcine reproductive and respiratory syndrome virus. J Vet Diagn Invest 12, 75-8.

Warris, P.D. (1984) Exsanguination of animals at slaughter and the residual blood content of meat. Vet Rec 115, 292-295

Wasilk, A., Callahan, J.D., Christopher-Hennings, J., Gay, T.A., Fang, Y., Dammen, M., Reos, M.E., Torremorell, M., Polson, D., Mellencamp, M., Nelson, E. and Nelson, W.M. (2004). Detection of U.S., Lelystad, and European-like porcine reproductive and respiratory syndrome viruses and relative quantitation in boar semen and serum samples by real-time PCR. J Clin Microbiol 42, 4453-61.

Wellenberg, G.J., Stockhofe-Zurwieden, N., Boersma, W.J., De Jong, M.F. and Elbers, A.R. (2004). The presence of co-infections in pigs with clinical signs of PMWS in The Netherlands: a case-control study. Research in Veterinary Science 77, 177184.

Wensvoort, G. (1992). Antigenic comparison of LV from Europe and United States and persistence in affected herds. American Association of Swine Practitioners Newsletter 4, 46.

Wensvoort, G., Terpstra, C., Pol, J.M.A., ter Laak, E.A., Bloemraad, M., de Kluyver, E.P., Kragten, C., van Buiten, L., den Besten, A., Wagenaar, F., Broekhuijsen, J.M., Moonen, P.L.J.M., Zetstra, T., de Boer, E A., Tibben, H.J., de Jong, M.F., van't Veld, P., Groenland, G.J.R., van Gennep, J.A., Voets, M.T., Verheijden, J.H.M., and Braamskamp, J.1991a). Mystery swine disease in the Netherlands: the isolation of Lelystad virus. Veterinary Quarterly 13, 121-130.

Wensvoort, G., Terpstra, C., Pol, J.M.A., Wagenaar, F. (1991b). Lelystad virus, the cause of Porcine Epidemic Abortion and Respiratory Syndrome (Mystery Swine Disease). Report of the Second Seminar of the EC on Porcine Reproductive and Respiratory Syndrome (the new pig disease), Brussels, Belgium, 4-5 November 1991. PVET/EN/0207, 27-35.

Wensvoort, G., de Kluyver, E.P., Luijtze, E.A., den Besten, A., Harris, L., Collins, J.E., Christianson, W.T., and Chladek, D.(1992). Antigenic comparison of Lelystad virus and swine infertility and respiratory syndrome (SIRS) virus. Journal of Veterinary Diagnostic Investigation 4, 134-138.

Wensvoort, G., Meulenberg, J.J.M., Murtaugh, M.P., Benfield, D., Nelson, E.A., Conzelmann, K., Thiel, H.J., Albina, E., Drew, T.W. (1993). The porcine reproductive and respiratory syndrome: Characteristics and diagnosis of the causative virus. Veterinary Biotechnology Newsletter. 3, 113-120.

Wheeler, T.L., Shackelford, S.D., Koohmaraie, M. (2000) Variation in proteolysis, sarcomere length, collagen content and tenderness among major pork muscles. J. Anim. Science 78, 958-965

White, M.E.C. (1992a). PRRS - Clinical update. Pig Veterinary Journal 29, 179-185. 
White, M.E.C. (1992b). The clinical signs and symptoms of 'blue eared pig disease' (PRRS). Pig Veterinary Journal 28.

Wills, R.W., Zimmerman, J.J., Swenson, S.L., Yoon, K.J., Hill, N.T., Bundy, D.S. and McGinley, M.J. (1994). Transmission of porcine reproductive and respiratory syndrome virus: contact versus airborne routes. Proceedings of the NC Conference of Veterinary Laboratory Diagnosis, Manhattan, KS.

Wills, R. W., Zimmerman, J. J., Swenson, S. L., Yoon, K. J., Hill, H. T., Bundy, D. S., and Mcginley, M. J.(1997a). Transmission of PRRSv by Direct, Close, or Indirect Contact. Swine Health and Production 5, 213-218.

Wills, R.W., Zimmerman, J.J., Yoon, K.J., Swenson, S.L., McGinley, M.J., Hill, H.T., Platt, K.B., Christopher-Hennings, J. and Nelson, E.A. (1997b). Porcine reproductive and respiratory syndrome virus: a persistent infection. Vet Microbiol 55, 231-40.

Wills, R. W., Doster, A. R., and Osorio, F. A.(2002). Transmission of porcine reproductive and respiratory syndrome virus (PRRSV) to age-matched sentinel pigs. Journal of Swine Health and Production 10, 161-165.

Xiao, Z., Batista, L., Dee, S., Halbur, P.G. and Murtaugh, M.P. (2004). The level of virusspecific T-cell and macrophage recruitment in porcine reproductive and respiratory syndrome virus infection in pigs is independent of virus load. J Virol 78, 5923-33.

Yaeger, M.J., Prieve, T., Collins, J.E., Christopher-Hennings, J., Nelson, E., Benfield, D.A. (1993). Evidence for the transmission of porcine reproductive and respiratory syndrome (PRRS) virus in boar semen. Swine Health and Production 1, 7-9.

Yang, L., Yoon, K.J., Li, Y., Lee, J.H., Zimmerman, J.J., Frey, M.L., Harmon, K.M. and Platt, K.B. (1999). Antigenic and genetic variations of the $15 \mathrm{kD}$ nucleocapsid protein of porcine reproductive and respiratory syndrome virus isolates. Arch Virol 144, 525-46.

Yoon, I.J., Joo, H.S., Christianson, W.T., Kim, H.S., Collins, J.E., Morrison, R.B., Dial, G.D. (1992a). Serologic response of pigs following experimental and natural infection with virus of porcine epidemic abortion and respiratory syndrome. Proceedings of the 12th Congress of the International Pig Veterinary Society, The Hague, Netherlands, 17-20th August, 1992. 124.

Yoon, I.J., Joo, H.S., Christianson, W.T., Kim, H.S., Collins, J.E., Carlson, J.H., and Dee, S.A. (1992b). Isolation of a cytopathic virus from weak pigs on farms with a history of swine infertility and respiratory syndrome. Journal of Veterinary Diagnostic Investigation 4, 139-143.

Yoon, I.J., Joo, H.S., Christianson, W.T., Morrison, R.B., Dial, G.D. (1993). Persistent and contact infection in nursery pigs experimentally infected with porcine reproductive and respiratory syndrome (PRRS) virus. Swine Health and Production. 1, 5-8.

Yoon, K.J., Zimmerman, J.J., Mcginley, M.J., Landgraf, J., Frey, M.L., Hill, H.T., and Platt, K.B.(1995a). Failure to consider the antigenic diversity of porcine reproductive and respiratory syndrome (PRRS) virus isolates may lead to misdiagnosis. Journal of Veterinary Diagnostic Investigation 7, 386-387.

Yoon, K.J., Zimmerman, J.J., Swenson, S.L., Mcginley, M.J., Eernisse, K.A., Brevik, A., Rhinehart, L.L., Frey, M.L., Hill, H.T., and Platt, K.B.(1995b). Characterization of the humoral immune response to porcine reproductive and respiratory syndrome (PRRS) virus infection. Journal of Veterinary Diagnostic Investigation 7, 305-312.

Yoon, K.J., Zimmerman, J.J., McGinley, M., Eerneese, K., Swenson, S.L., Frey, M.L., Platt, K. (1995c). Comparison of the performance of ELISA to other PRRS serological assays. Abstracts of the Second International Symposium on Porcine 
Reproductive and Respiratory Syndrome (PRRS), Copenhagen, Denmark, August 9th-10th, 1995. 16.

Yoon, K.J., Henry, S.C., Zimmerman, J.J., and Platt, K.B.(1996). Isolation of porcine cytomegalovirus from a swine herd with PRRS. Veterinary Medicine 91, 779-784.

Yoon, K.J., Wu, L.L., Zimmerman, J.J. and Platt, K.B. (1997). Field isolates of porcine reproductive and respiratory syndrome virus (PRRSV) vary in their susceptibility to antibody dependent enhancement (ADE) of infection. Vet Microbiol 55, 277-87.

Yoon, K.J., Zimmerman, J.J., Chang, C.C., Cancel-Tirado, S., Harmon, K.M. and McGinley, M.J. (1999). Effect of challenge dose and route on porcine reproductive and respiratory syndrome virus (PRRSV) infection in young swine. Vet Res 30, 629-38.

Yoon, K., Christopher-Hennings, J., Nelson, E.A. (2003). Diagnosis of PRRS Virus. In: PRRS Compendium - Producer Edition. National Pig Meat Board.

Zeman, D., Neiger, R., Yaeger, M., Nelson, E., Benfield, D., Leslie-Steen, P., Thomson, J., Miskimins, D., Daly, R. and Minehart, M. (1993). Laboratory investigation of PRRS virus infection in three swine herds. J Vet Diagn Invest 5, 522-8.

Zhou, E., Zimmerman, J.J., Zhou, K.X. (2001). Development of a blocking ELISA for detection of swine antibodies to PRRSv. Proceedings of the American Association of Veterinary Laboratory Diagnosticians, p. 60.

Zimmerman, J.J., Sanderson, T., Eernisse, K., Hill, H. and Frey, M.L. (1992). Transmission of SIRS virus from convalescent animals to commingled penmates under experimental conditions. In: Proceedings of International Symposium on SIRS/PRRS/PEARS, St. Paul, Minnesota, USA, pp 17.

Zimmerman, J.J., Swenson, S.L., Wills, R.W., Pirtle, E.C., Yoon, K.J., Hill, H.T., McGinley M.J. (1993). Transmission of PRRS virus. Proceedings of the Allen D Leman Swine Conference, University of Minnesota, USA. 51-52.

Zimmerman, J.J., Yoon, K.J., Pirtle, E.C., (1997). Studies of porcine reproductive and respiratory syndrome (PRRS) virus infection in avian species. Vet Microbiol 55:329-336. 


\section{Acknowledgements}

The working group drafted the scientific risk assessment, which was then reviewed and revised by the Panel. The working group was chaired by Dr. Per Have. In addition to the AHAW Panel members Profs. Martin Wierup and Prof. José Sanchez Vizcaino the members of the working group were:

Dr. Per Have

Danish Institute for Food and Veterinary Research (DFVF)

Bülowsvej 27

DK-1790 Copenhagen

Denmark

Lis Alban DVM, PhD

DanskeSlagterier Landsudvalget for Svin

Denmark

Dr. Trevor Drew

Head of Virology Department

Veterinary Laboratories Agency

Woodham Lane, New Haw,

Addlestone Surrey KT15 3NB

United Kingdom

Dr. Marie-Frédérique Le Potier

Agence Française de Securité Sanitaire des Aliments (AFSSA)

Unité Virologie Immunologie Porcines

Les Croix BP 53

F-22440 Ploufragan

France

Prof. Michael P. Murtaugh, PhD

Director, USDA PRRS Integrated Program Project Co-Director

Mucosal and Vaccine Research Center

Department of Veterinary \& Biomedical Sciences College of Veterinary Medicine University of Minnesota

1971 Commonwealth Avenue

St. Paul MN 55108

USA

Prof. Dr. H. J. Nauwynck

Laboratory of Virology

Faculty of Veterinary Medicine

Ghent University

Salisburylaan 133

9820 Merelbeke

Belgium

Dr. Gerard Wellenberg

Animal Health Service institute

Arnsbergstraat 7

Postbus 9

7400 AA Deventer 
The Netherlands

Dr. Jeffrey J. Zimmerman

Associate Professor

Department of Veterinary Diagnostic and Production Animal Medicine

College of Veterinary Medicine

lowa State University

USA 


\section{AHAW Scientific Panel Members}

\section{Bo Algers}

Department of Animal Environmental and Health,

Swedish University of Agricultural Sciences,

Skara,

Sweden

Harry J. Blokhuis

Animal Sciences Group,

Wageningen University and Research Centre,

Lelystad,

The Netherlands

Donald Maurice Broom

Department of Clinical Veterinary Medicine,

University of Cambridge,

Cambridge,

United Kingdom

Ilaria Capua

Istituto Zooprofilattico Sperimentale delle Venezie,

Legnaro, Padova,

Italy

\section{Stefano Cinotti}

Facolta di Medicina Veterinaria Alma Materstudiorum,

Università di Bologna,

Bologna,

Italy

\section{Michael Gunn}

Department of Agriculture and Food,

Veterinary Research Laboratory,

Dublin,

Ireland

Jörg Hartung

Institute for Animal Hygiene, Animal Welfare and Behaviour of Farm Animals, University of Veterinary Medicine Hanover,

Hanover,

Germany

\section{Per Have}

Danish Institute for Food and Veterinary Research,

Copenhagen,

Denmark

\section{Xavier Manteca Vilanova}

School of Veterinary Science,

Universitat Autònoma de Barcelona,

Barcelona,

Spain

David B. Morton

Biomedical Services Unit,

University of Birmingham, 
Birmingham, United Kingdom

Michel Pépin

Laboratoire d'Etudes et de Recherches sur les Petits Ruminants et les Abeilles, Agence Française de Securité Sanitaire des Aliments (AFSSA),

Sophia Antipolis,

France

Dirk Udo Pfeiffer

Royal Veterinary College,

University of London,

London,

United Kingdom

Ronald John Roberts

University of Stirling,

Stirling,

United Kingdom

José Manuel Sánchez Vizcaino

Facultad de Veterinaria,

Universidad Complutense de Madrid,

Madrid,

Spain

Alejandro Schudel

Office International des Epizooties,

Paris,

France

James Michael Sharp

Department of Pathology,

Veterinary Laboratories Agency,

Penicuik,

United Kingdom

Georgios Theodoropoulos

Department of Anatomy and Physiology of Farm Animals,

Faculty of Animal Science,

Agricultural University of Athens,

Athens,

Greece

Philippe Vannier

Poultry and Swine Research Laboratory,

Agence Française de Securité Sanitaire des Aliments (AFSSA),

Ploufragan,

France

Marina Verga

Facoltà di Medicina Veterinaria,

Università di Milano,

Milano,

Italy

Martin Wierup

Department of Biomedical Sciences and Veterinary Public Health,

Swedish University of Agricultural Sciences, 


\section{Uppsala,}

Sweden

\section{Marion Wooldridge}

Centre for Epidemiology and Risk Analysis,

Veterinary Laboratories Agency,

Weybridge,

United Kingdom 